\title{
The impact of canopy composition on the nutritional status of an admixed spruce and beech forest at Solling, central Germany
}

Dissertation

\author{
Submitted for the Ph.D degree \\ of Forest Sciences and Forest Ecology \\ Georg-August - university of Goettingen
}
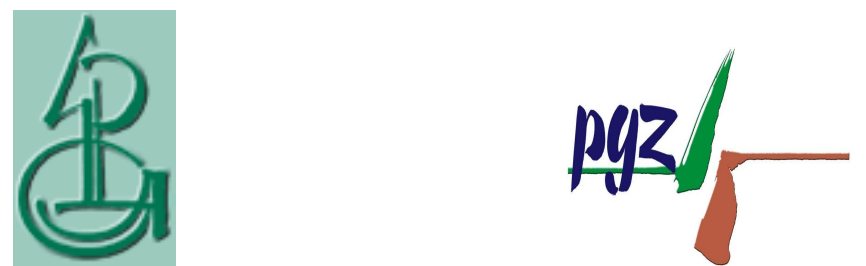

by

Seyed Mohammad Hojjati

Born in Babol - Iran

Goettingen, February, 2008 
D7

1. Referees: Prof. Dr. Friedrich Beese and Prof. Dr. Norbert P. Lamersdorf

2. Referee: Prof. Dr. Achim Dohrenbusch

Date of Oral Examination: 14.02.2008

Full text document is available through the following address:

http://webdoc.sub.gwdg.de/diss/ 2008/hojjati/index.html 
TO:

SOMAYE \& YUNA 


\section{Table of contents}

Acknowledgement...................................................................10

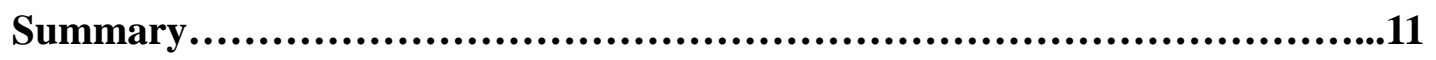

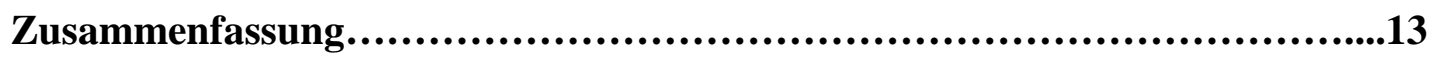

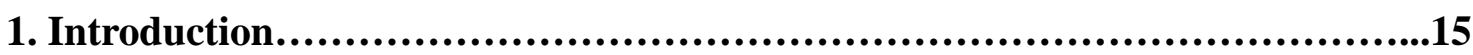

1.1. Canopy composition and nutrient input........................................16

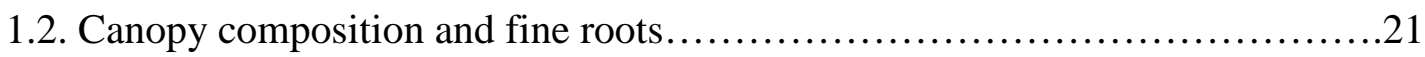

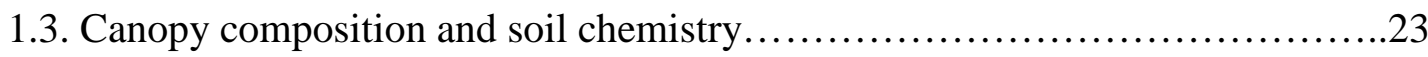

1.4. Canopy composition and soil solution chemistry.............................24

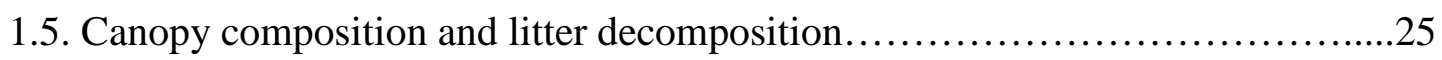

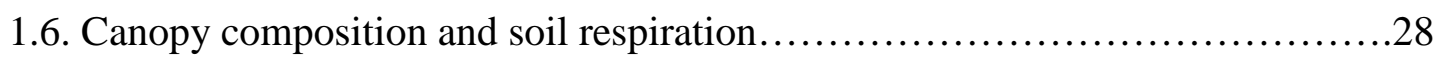

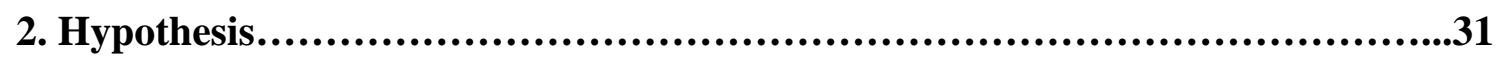

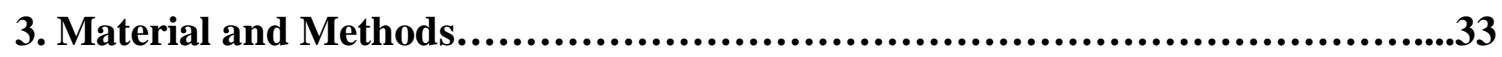

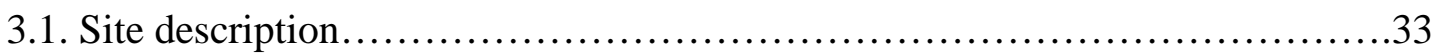

3.2. Data collection, field measurements and chemical analysis......................36

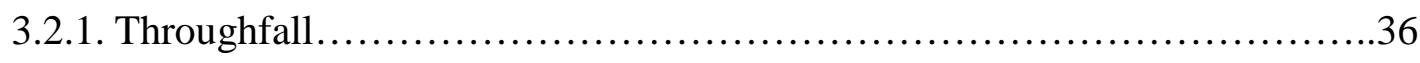

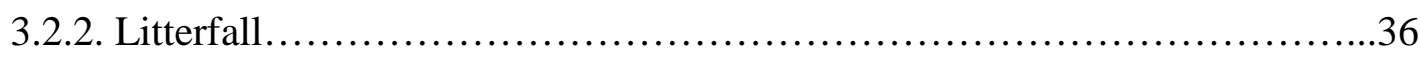

3.2.3. Forest floor and mineral soil.........................................................................

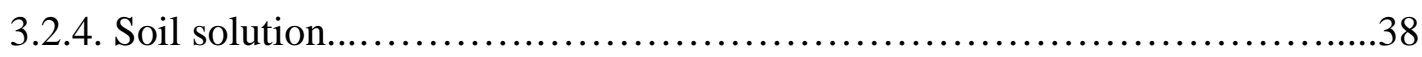

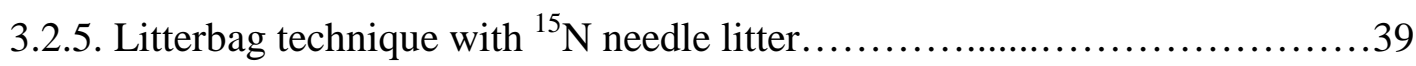

3.2.6. Soil respiration ............................................................ 40

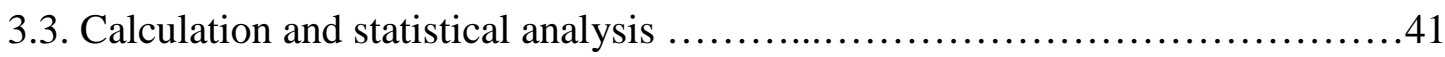

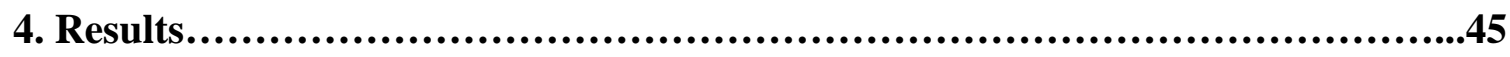

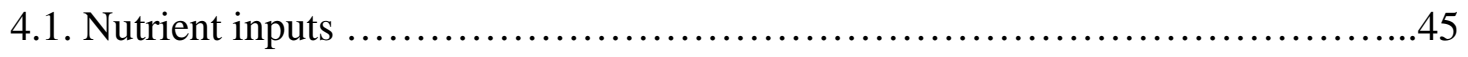


4.1.1. Throughfall .......................................................45

4.1.2. Litterfall............................................................. 49

4.1.3. Total element inputs................................................52

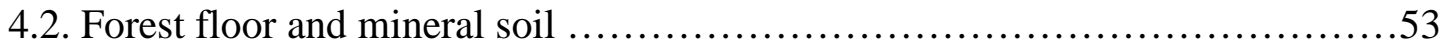

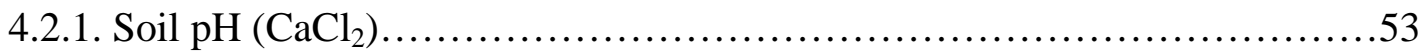

4.2.2. Concentration and storage of elements in the forest floor ..................54

4.2.3. Concentration and storage of elements in the mineral soil layers .............58

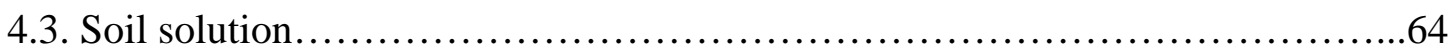

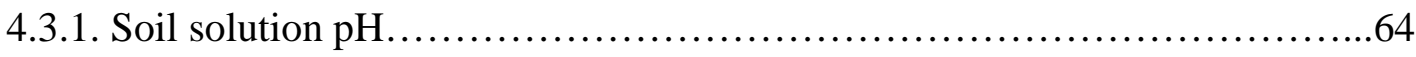

4.3.2. Ion concentration .................................................64

4.4. Litter decomposition and nitrogen turnover....................................

4.4.1. Remaining mass and carbon in decomposing needle litter................. 67

4.4.2. $\mathrm{N}$ dynamics in decomposing needle litter............................... 69

4.5. Soil respiration....................................................... 72

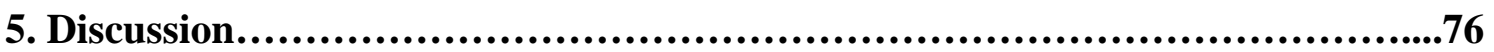

5.1. Throughfall ...................................................... 76

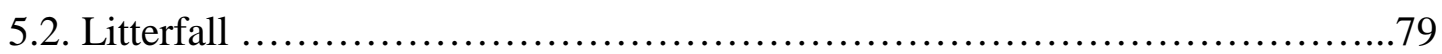

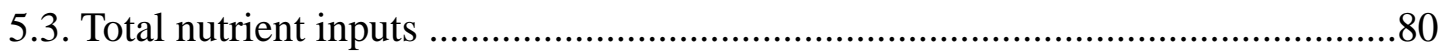

5.4. Forest floor and mineral soil......................................... 81

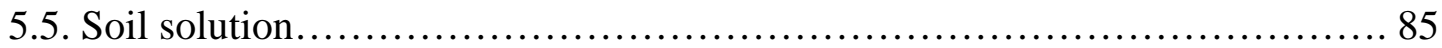

5.6. Litter decomposition and nitrogen turnover............................. 90

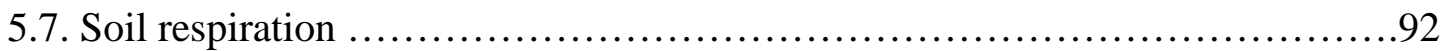

6. Conclusion...........................................................................

7. References...........................................................................97 


\section{List of tables}

Tab.1. Comparison of mean annual water and element fluxes via throughfall in pure beech and in pure spruce stands under the same site conditions from different references.................................................... 19

Tab.2. Mean annual litterfall, soil respiration and $O$-horizon $C$ stock in different references............................................................ 30

Tab.3. Stand characteristics of the beech $(B D P)$ and spruce $(S D P)$ dominated plot

Tab.4. Mean annual water and element fluxes $( \pm S D)$ of bulk precipitation $(n=3)$ from F1 plot in Solling according to Meesenburg (2006, personal communication).

Tab.5. Mean $( \pm S D)$ annual water and element fluxes via throughfall in the beech $(B D P)$ and spruce $(S D P)$ dominated plot $\left(g / m^{2} . y r\right)$. 46

Tab.6. Mean $( \pm S D)$ annual dry mass of different litterfall compartments under different canopy classes in the beech (BDP) and spruce (SDP) dominated plot $\left(\mathrm{g} / \mathrm{m}^{2} \cdot \mathrm{yr}\right)$......

Tab.7. Mean ( $\pm S D)$ annual mass and element fluxes via foliar litterfall under different canopy classes in the beech (BDP) and spruce (SDP) dominated plots $\left(\mathrm{g} / \mathrm{m}^{2} \cdot y r\right)$.....

Tab.8. Total annual input of elements via throughfall $(T F)$ and litterfall $(L F)$ under different canopy classes in the beech $(B D P)$ and spruce $(S D P)$ dominated plots.

Tab.9. $\quad$ Mean $( \pm S D)$ characteristics of the organic layers under different canopy classes in the beech (BDP) and spruce (SDP) dominated plot.... 56

Tab.10. Mean $( \pm S D)$ element storage in the organic layer $\left(O_{L+F}\right.$ and $\left.O_{H}\right)$ in different sub-plots in the beech (BDP) and spruce (SDP) dominated plot........ 57

Tab.11. Mean ( $\pm S D)$ characteristics of the mineral soil layers in different sub-plots in the beech $(B D P)$ and spruce $(S D P)$ dominated plot.

Tab.12. Mean $( \pm S D)$ element storage in the mineral soil layer $(0-40 \mathrm{~cm}$ depth $)$ in different sub-plots of the beech (BDP) and spruce (SDP) dominated plot.

Tab.13. Mean $( \pm S D)$ concentration of elements and molar ratios of BC/Al in soil solution extracted from 10 and $100 \mathrm{~cm}$ depths of mineral soil under different canopy classes in the beech (BDP) and spruce (SDP) dominated plot from Oct 2003 to July 2006. 
Tab.14. Mean ( $\pm S D)$ annual decomposition rate ( $k, n=10$, for 12 months of in situ incubation) and the correlation coefficient between the $k$ constant and needle decomposition time ( $n=75$, for 15 months) in different sub-plots of the beech (BDP) and spruce (SDP) dominated plot....

Tab.15. Mean rates of soil respiration, annual soil respiration $\left(S_{\text {res }}\right)$, annual $C$ inputs via foliar litterfall $\left(C_{\text {lit }}\right)$, root-associated $\mathrm{CO}_{2}$ production $\left(R_{\text {res }}\right)$ and $R_{\text {res }} / S_{\text {res }}$ ratios in different sub-plots of the beech $(B D P)$ and spruce $(S D P)$ dominated plot.

Tab.16. The SDP / BDP ratio of water and element fluxes via throughfall for different canopy classes...

Tab.17. Mean annual water ( $\mathrm{mm})$ and elements $\left(\mathrm{g} / \mathrm{m}^{2} . y \mathrm{r}\right)$ fluxes at $100 \mathrm{~cm}$ soil depth under different canopy classes in the beech (BDP) and spruce (SDP) dominated plot.

\section{List of figures}

Fig.1. $\quad$ Simplified causal diagram showing the main ecosystem characteristics which may be influenced by the canopy composition in a forest stand... 16

Fig.2. Relationship between soil respiration and $C$ stock in $O$ horizon in different

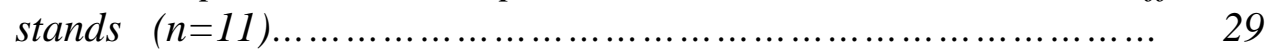

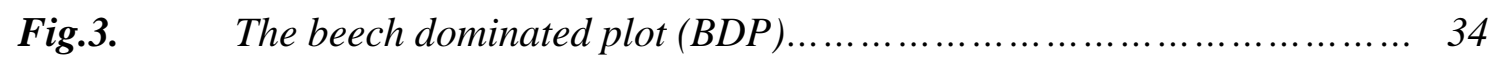

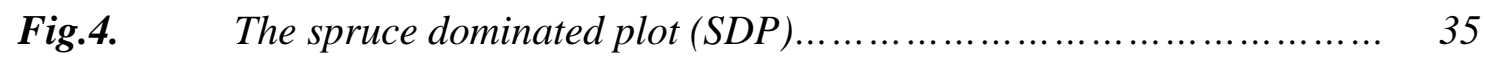

Fig.5. Litter traps installed under the canopy of central beech tree in the spruce dominated plot (SDP)....

Fig.6. Placing of litterbags in the field................................... 40

Fig.7. $\quad$ Mean $p H$ values $( \pm S D)$ of throughfall in leafed and leafless periods under different canopy classes in a) beech $(B D P)$ and $b)$ spruce $(S D P)$ dominated plots and in bulk precipitation.

Fig.8. Mean $( \pm S D)$ annual canopy leaching of base cations under different canopy classes in the a) beech (BDP) and b) spruce (SDP) dominated plots. Different letters indicate significant $(p<0.05)$ differences between canopy classes....................................................................... 48

Fig.9. Monthly leaf and needle litter distribution under different canopy classes in the beech $(B D P)$ and spruce $(S D P)$ dominated plots. 
Fig.10. Mean $( \pm S D)$ element concentration in leaf $(a)$ and needle $(b)$ litter in the beech $(B D P)$ and spruce $(S D P)$ dominated plots. Different letters indicate significant $(p<0.05)$ differences between plots. ....................... 51

Fig.11a,b. Vertical patterns of $\mathrm{pH}$ values from the $O_{H}$ layer down to the $40 \mathrm{~cm}$ soil depth in different sub-plots, (a) beech (BDP) and (b) spruce (SDP) dominated plot. ................................................................... 54

Fig.12a,b. Storage of $\mathrm{C}, \mathrm{N}, \mathrm{S}$ and cations $\left(\mathrm{K}^{+}, \mathrm{Ca}^{2+}, \mathrm{Mg}^{2+}\right.$ and $\left.\mathrm{Al}^{3+}\right)$ in the organic $\left(O_{L+F}\right.$ and $\left.O_{H}\right)$ and the mineral soil layers $(0-40 \mathrm{~cm}$ depth) in different subplots of the $(a)$ beech $(B D P)$ and $(b)$ spruce $(S D P)$ dominated plot (continued on next page).... $.61-62$

Fig.13. Mean pH values ( $\pm S D$ ) of soil solution (at $10 \mathrm{~cm}$ depth of mineral soil) in different sub-plots of the beech (BDP) and spruce (SDP) dominated plot

Fig.14a,b. Percentage of remaining to initial mass during the decomposition of needle litter incubated from May 2005 to July 2006 under different canopy classes (sub-plots) in the (a) beech (BDP) and (b) spruce (SDP) dominated plot. 68

Fig.15a,b. Changes of the percentages of remaining to initial carbon of decomposing needle litter after the incubation from May 2005 to July 2006 in different sub-plots of the (a) beech (BDP) and (b) spruce (SDP) dominated plot....

Fig.16a,b. Changes in the decomposition rate ( $k$ constant) of decomposing needle litter after the incubation from May 2005 to July 2006 in different sub-plots of the (a) beech (BDP) and (b) spruce (SDP) dominated plot.

Fig.17a,b. Relation between $N$ concentration of decomposing needle litter and the time of litterbag incubation in different sub-plots of the (a) beech (BDP) and (b) spruce (SDP) dominated plot..... 70

Fig.18a,b. Temporal variation of total $N(\boldsymbol{\square}), N$ release $(\diamond)$ and $N$ incorporation $(\boldsymbol{\Delta})$ in the decomposing litter after the incubation from May 2005 to July 2006 in different sub-plots of the (a) beech (BDP) and (b) spruce (SDP) dominated plot. Erorr bars indicate standard error deviation of the mean $( \pm S D$, $n=5)$

Fig.19a,b. Changes in C/N ratios of decomposing needle litter during the period of litterbag incubation (May 2005 to July 2006) within the forest floor in different sub-plots of the (a) beech (BDP) and $(b)$ spruce $(S D P)$ dominated plot.

Fig.20a,b. Mean monthly water flux via throughfall (mm) from June 2005 to July 2006 in the different sub-plots of the a) beech (BDP) and b) spruce (SDP) dominated plot..... 
Fig.21a,b. Temporal variation of mean soil temperatures $\left({ }^{\circ} \mathrm{C}\right)$ at $10 \mathrm{~cm}$ depth from June 2005 to July 2006 in different sub-plots of the a) beech (BDP) and b) spruce (SDP) dominated plot.

Fig.22a,b. Temporal variation of mean rate of soil respiration ( $\left.\mathrm{mg} C / \mathrm{m}^{2} . h\right)$ from June 2005 to July 2006 in different sub-plots of the a) beech (BDP) and b) spruce (SDP) dominated plot. 74

Fig.23a,b. Relation between the rate of soil respiration and the soil temperature at 10 cm depth in the a) beech (BDP) and b) spruce (SDP) dominated plot... 75

Fig.24a,b. Annual hydrochemical budget (input $=$ fluxes via throughfall /output=fluxes of seepage water at $100 \mathrm{~cm}$ depth of mineral soil) for the period of May 2005-April 2006 under different canopy classes in the (a) beech (BDP) and (b) spruce (SDP) dominated plot .89 


\section{Acknowledgments:}

I am grateful to Prof. Dr. Norbert P. Lamersdorf for his strong interest in the subject and his kind supervision of this thesis. He offered me the opportunity to work on a very interesting topic in forest research and helped me very much in all stages of the work.

My sincere gratitude is to Prof. Dr. Friedrich Beese as the director of the Buesgen Institute Soil Science of Temperate and Boreal Ecosystems and also taking over the first reference of my.

I am grateful also to Prof. Dr. Achim Dohrenbusch for taking over the second reference of my dissertation.

I am indebted to Dr. Anna Hagen-Thorn for her precise advices and her scientific support during the last two years of my research and her cooperation to write the first submitted manuscript.

I would like to express my gratitude to the Iranian Ministry of Sciences, Researches and Technology (MSRT) for funding that made my Ph.D study possible.

I would like to thank the Buesgen Institute - Soil Science of Temperate and Boreal Ecosystems of the Georg-August University of Göttingen for its great hospitality, expertise and all the technical and financial support provided in field equipment installations, data collection and chemical analyses. I am particularly grateful to Dirk Böttger and Nico Frischbier for their expert technical assistance and to all the laboratory assistants at the Institute for analysing the samples.

I am highly grateful to my parents, Mr. Seyed Hossein Hojjati and Mrs. Maryam Dadashi, to encourage and support me over my entire life.

I give my best thanks to my lovely spouse Mrs. Somaye Razzaghi and my son Yuna for their patience, understanding and encouragements. 


\section{Summary}

It was hypothesised that in mixed spruce-beech forest ecosystems the heterogeneity in canopy composition may create different micro-sites (units) in the forest floor and the mineral soil with different ecological characteristics. Therefore, different types of canopy compositions (canopy classes) were used to identify the variability of water and element fluxes (via throughfall and litterfall), soil and soil solution chemistry, litter decomposition and soil respiration. The investigation was carried out in a mixed sprucebeech stand in Solling, central Germany. Two different plots were selected for this study representing the most contrasting cases of mixed forests types, which were i) a site greatly dominated by spruce trees (the spruce dominated plot, SDP) with two beech trees in-between and ii) a directly neighbouring site which was dominated by beech trees and having a single spruce tree in-between (the beech dominated plot, BDP). The canopies of the two plots were classified in four categories: pure beech, pure spruce, mixed canopy and gap.

Throughfall water was significantly lower and major element fluxes were higher under spruce than under beech in both plots. This indicated that the nutrient inputs under the canopies of individual trees were driven by species-specific properties of the canopies and were quite independent of the degree of admixture. With the exception of $\mathrm{K}^{+}$, mixed canopies showed intermediate element inputs via throughfall, compared with pure canopy classes. The $\mathrm{K}^{+}$input, however, was significantly greater under mixed canopies due to interactions of the canopies, leading to higher leaching rates for $\mathrm{K}^{+}$.

Throughfall was the main source of heterogeneity in nutrient inputs, while foliar litterfall input was almost equal between sub-plots and thus had a homogenising effect on annual nutrient fluxes in the beech-spruce mixed stands.

Differences in soil chemistry under different canopy classes were mainly observed in the forest floor and top mineral soil layers. Significant effects of the canopy composition on $\mathrm{pH}\left(\mathrm{CaCl}_{2}\right)$ values of the forest floor and mineral soil were detected between the gap (significantly higher) and spruce (significantly lower) sub-plots in the spruce dominated plot (SDP). The water fluxes (lower under spruce) and chemistry (higher concentration of elements under spruce) of throughfall could explain theses differences.

In spite of almost equal litterfall inputs, different masses of organic matter (humuslayer) were observed in the forest floor of different sub-plots for both plots, SDP and BDP. 
Differences were most pronounced between the spruce, beech and gap sub-plots (spruce $\geq$ beech $\geq$ gap).

The soil solution at $10 \mathrm{~cm}$ soil depth showed significantly higher $\mathrm{pH}$ values in the beech sub-plots, compared with the spruce sub-plots. This finding may be linked to different water and element fluxes via throughfall between sub-plots.

A significant effect of the canopy composition on the rate of litter decay and the soil $\mathrm{CO}_{2}$ efflux was observed in the beech dominated plot (BDP). Here, the beech and gap sub-plots showed significantly lower remaining masses at the end of the incubation period (about one year after incubation) compared with the spruce sub-plot. This may indicate that the early stage of the decomposition process was not governed by the given canopy composition. The beech sub-plot showed significantly higher soil respiration, compared with the gap sub-plot. An estimation of the root-associated $\mathrm{CO}_{2}$ production revealed considerably lower root respiration in the gap sub-plot compared with the other sub-plots in the BDP.

In total, it was shown that the selected canopy classes were able to create specific biogeochemical patterns in the investigated mixed beech-spruce forest. However, the impact of an individual spruce tree in a beech-dominated site induced obviously higher degrees of spatial heterogeneity with respect to nutrient inputs via throughfall, litter decomposition and soil respiration compared to individual beech trees in a sprucedominated site. 


\section{Zusammenfassung}

In einem Mischwald aus Buche und Ficht im Solling wurde der Einfluss des Kronenraums auf den Stoffhauhalt des Ökosystems untersucht. Dabei lautete die Arbeithypothese, dass die Mischungsanteile der Baumkronen ein spezifisches Muster an bio-geochemischer Heterogenität erzeugen, welches sich im Bestand über den Stoffeintrag bzw. über bodenökologische Kennwerte nachweisen lässt. Zum Nachweis derartiger Muster wurden so genannte Kronenraumklassen ausgeschieden, für die jeweils die Wasser- und Elementflüsse (Kronentraufe und Streufall), der Boden und die Bodenlösung, die Streuzersetzung und die Bodenatmung untersucht wurden. Die Untersuchungen wurden an zwei unterschiedlichen Flächen vorgenommen, die sich hinsichtlich des Mischungsanteils extrem unterschieden: i) eine von Fichten dominierte Fläche, bei der lediglich 2 einzelne Buchen eingemischt waren (im Folgende bezeichnet als SDP, "Spruce Domiated Plot") und ii) eine unmittelbar benachbarte und von Buchen dominierte Fläche, mit nur einer einzelnen Fichte im Zentrum (BDP, "Beech Dominated Plot"). Jeder Plot wurde unterteilt nach folgenden Kronenraumklassen (Teilflächen): "reine Buche", "reine Fichte", "gemischt" und "Freifläche" (gap).

Folgende Ergebnisse wurden erzielt: Für beide Flächen, SDP und BDP war der Wasserfluss mit der Kronentraufe unter der Teilfläche "reine Fichte" gegenüber dem unter "reiner Buche" signifikant reduziert, der Elementeintrag jedoch generell erhöht. Es wird auf eine vom Mischungsanteil unabhängige und primär durch die Baumart bestimmte Eintragsfunktion geschlossen. Mit Ausnahme von $\mathrm{K}^{+}$zeigten sich für die Kronenraumklasse "gemischt" mittlere Eintragsraten mit der Kronentraufe, verglichen mit den jeweiligen Klassen "reine Buche" bzw. "reine Fichte". Für $\mathrm{K}^{+}$wurde ein signifikant höherer Eintrag unter den gemischten Kronenraumbereichen ermittelt. Es wird auf ein durch die Interaktion der Baumkronen induziertes höheres Leaching von $\mathrm{K}^{+}$ geschlossen.

Insgesamt erwies sich die Kronentraufe als wesentlicher Faktor zur Förderung der stofflichen Heterogenität in den Untersuchungsflächen. Dagegen zeigen die stofflichen Einträge mit der Streu nahezu ähnliche Eintragsraten und tragen somit zur stofflichen Homogenität im Buchen-Fichten Mischwald bei.

Unterschiede in bodenchemischen Eigenschaften waren nur für die organische Auflage und den mineralischen Oberboden nachweisbar. So wurden signifikant höhere pH-Werte $\left(\mathrm{CaCl}_{2}\right)$ auf der Freifläche (gap) und signifikant niedrigere $\mathrm{pH}$-Werte unter "reiner 
Fichte" in der Humusauflage und im Oberboden für die Fläche SDP festgestellt. Diese Ergebnisse wurden auf höhere Elementeinträge bei einem gleichzeitig geringeren Wasserfluss unter Fichte zurückgeführt.

Trotz der nahezu gleich hohen Einträge an Streu wurden für die Mengen an akkumuliertem organischem Material (Humuslagen) deutliche Unterschiede zwischen den Teilflächen für beide Untersuchungsflächen, SDP und BDP, festgestellt. Besonders deutlich prägten sich diese Unterschiede zwischen den Teilflächen und in der Reihenfolge "reine Fichte" $\geq$ "reine Buche" $\geq$ Freifläche aus.

Für die Bodenlösung in $10 \mathrm{~cm}$ Bodentiefe wurden signifikant höhere $\mathrm{pH}-\mathrm{Werte}$ unter "reiner Buche", verglichen mit den Teilflächen unter reiner Fichte ermittelt. Dieser Befund kann erklärt werden über unterschiedliche Element- und Wasserflüsse zwischen den Teilflächen.

Hinsichtlich der Rate der Streuzersetzung und der $\mathrm{CO}_{2}$-Bodenatmung wurde ein signifikanter Effekte für die Buchen-dominierte Versuchsfläche BDP diagnostiziert. Unter "reiner Buche" und für die Freifläche (gap) wurden geringere verbleibende Massen am Ende der Inkubationszeit (nach ca. $1 \mathrm{Jahr}$ ), im Vergleich zur Teilfläche "reine Fichten" ermittelt. Es wird auf eine von der Kronenklassifizierung unabhängige erste Phase der Streuzersetzung geschlossen. Zudem zeigte die Fläche "reine Buch" höhere $\mathrm{CO}_{2}$-Emissionsraten, verglichen mit der Freifläche (gap). Eine Abschätzung der wurzelbürtigen $\mathrm{CO}_{2}$-Freisetzung bestätigte den Befund einer geringeren $\mathrm{CO}_{2}$ Emissionsrate auf der Freifläche, verglichen mit den anderen Unterflächen.

Insgesamt konnte gezeigt werden, dass die ausgeschiedenen Kronenraumklassen tatsächlich ein spezifisches bio-geochemisches Muster im untersuchten Buchen-Fichten Mischwald erzeugt haben. Dabei bewirkt offensichtlich eine einzelne Fichte in einem Buchen-dominierten Bestand mehr an stofflicher Heterogenität im Hinblick auf den stofflichen Eintrag mit der Kronentraufe, die Streuzersetzung und die Bodenatmung, als einzelne Buchen in einem Fichten-dominierten Bestand. 


\section{Introduction}

In the last centuries, the natural European beech (Fagus sylvatica L.) dominated forests in central Europe have been replaced to a large extent by Norway spruce (Picea abies L. Krast.) plantations (Rothe et al., 2002b). These monocultures tend, however, to be more sensitive to natural and anthropogenic forms of stress such as storm events, insect attacks, droughts and other impacts of climate change. Mixed forest types are currently recommended by foresters in order to improve the stability and biodiversity value of forest ecosystems (Larsen 1995; Olsthoorn et al. 1999; Hooper et al., 2005). Admixture of beech trees to Norway spruce stands may have a positive impact on the biogeochemistry of forest ecosystems especially in areas with increased loads of atmospheric pollutants and on soil that is low in base cations (Sverdrup and Stjernquist, 2002).

Tree composition affects ecological properties on a small spatial scale (Zinke, 1962), and in a mixed forest the heterogeneity in the canopy composition may create different representative structural units (Wilpert and Mies, 1995) with different ecological characteristics, fluxes of water, nutrients and energy.

What is the importance of canopy in forest nutritional status?

The canopy is one of the most important components in forest ecosystems. It has been known for a long time that the forest canopy governs many biochemical processes in forest floor and top mineral soil layers (Zinke, 1962).

The characteristics of the canopy determines directly and indirectly the quality and quantity of litterfall, throughfall and stemflow, soil properties, rooting patterns, soil respiration and consequently the nutrient availability in forest stands (Fig.1). Therefore, at the same site conditions this may lead to different forest productivity (Binkley and Giardina, 1998; Rothe et al., 2003) depending on inter-specific differences in canopy characteristics. Hence, regarding to the nature of tree species, European beech and Norway spruce show different nutritional characteristics in monocultures. In the mixed beech - spruce stands, above and below ground interactions between the tow species may cause complex nutritional properties in forest ecosystems. This complexity may depend on the canopy composition. Prescott (2002) stated that the greater canopy complexity create similar heterogeneity in nutritional characteristics of the forest floor. Therefore, canopy composition might be hypothesizing to use as a determining factor to influence nutritional properties of forest soils. 


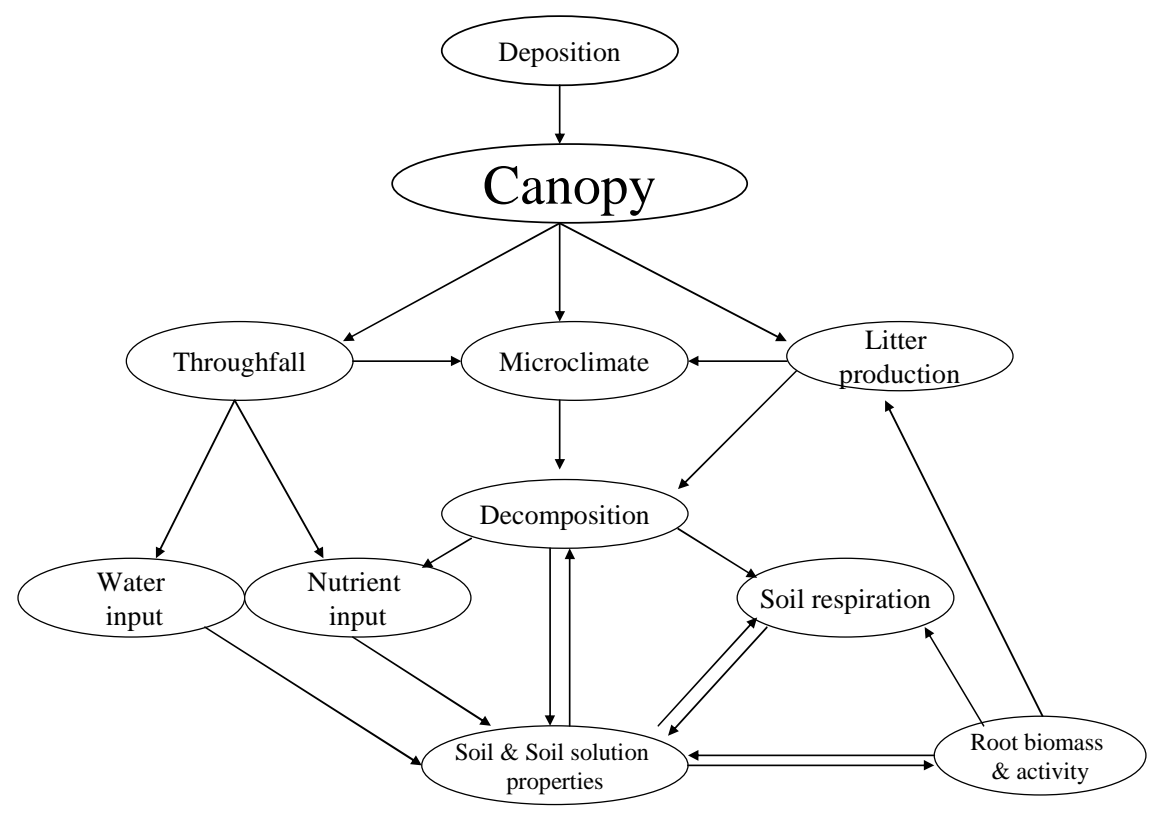

Fig.1: Simplified causal diagram showing the main ecosystem characteristics which may be influenced by the canopy composition in a forest stand.

\subsection{Canopy composition and nutrient input}

Litterfall and throughfall are known as the major pathways for transporting the elements from the forest canopies to the soils. The contribution of each of the two pathways is mainly dependent on the nature of elements, the properties of foliage and the acidity of the rain water (Lovett et al., 1996; Rothe et al., 2002; Stachurski and Zimka, 2002; Longusch et al., 2003; Hagen-Thorn et al., 2006). To find the best solution to maintain the forest soil nutrient status in a given environmental condition it is of crucial importance to know how the chemistry and amounts of throughfall and litterfall depend on changes in canopy properties and composition.

\section{Throughfall and Stemflow (Hydro-chemical pathways)}

Throughfall and stem flow make up to $90 \%$ of gross precipitation in temperate forest (Likens and Bormann, 1995; Muoghalu and Oakhumen, 2000) thus have a strong influence on biogeochemical cycles in forest ecosystems (Parker, 1983). Forest canopy can alter hydrological condition by re-directing precipitation, reducing snow accumulation and removing soil water through transpiration. 
Due to dry deposition and canopy exchange capacity the chemistry of rain water changes when passing through the canopy of the trees (Beier et al, 1993; Lovett et al, 1996; Bartsch, 2000; Levia Jr. and Frost, 2003). Canopy characteristics such as architecture, roughness, wetness and density as well as nutrient status of the foliage and branches influence the water amounts and chemistry of throughfall and stemflow (Khanna \& Ulrich, 1991). The canopy of spruce trees intercepts 30-40\% of gross precipitation (Benecke, 1984; Viville et al, 1993; Rothe, 1997) while beech canopy intercept only 17-20\% of gross precipitation (Benecke, 1984; Rothe, 1997).

Water and element fluxes via throughfall exhibit high spatial heterogeneity within the forest ecosystem (Zirlewagen and Wilpert, 2001) based on distance from the trunk and canopy architecture (Staelens at al, 2006). Under the canopy of spruce, water flux is higher in the edge of canopy and increases with the distance from the stem (Seiler and Matzner, 1995), whereas ion concentrations are higher close to the stems (Beier et al, 1993; Hansen, 1995; Whelan et al, 1998) due to foliage density. Beneath a beech canopy the spatial pattern of throughfall water amounts is also related to foliage density but due to heterogeneous crown structure of beech there is no such a steep gradient depending on the distance from the stem. Therefore the canopy of spruce with more circular and symmetric architecture may create more systematic spatial variability in throughfall (Zirlewagen and von Wilpert, 2001).

Compared to beech, spruce can intercept more precipitation as well as capturing more air particles and gasses because of denser foliage, higher LAI (Leaf Area Index) and higher foliage longevity (Rothe, 1997). Hence, throughfall samples under spruce are, in general, richer in elements compared to throughfall samples under beech in the same site condition (Tab.1). The $\mathrm{pH}$ of the throughfall under spruce is normally lower than under beech because spruce captures higher hydrogen loads from the atmosphere and has a lower capacity for proton buffering compared with broad-leaved species (Stachurski and Zimka, 2002). The amount and chemistry of throughfall in a mixed stand is not only influenced by the foliage surface properties of individual trees but is also affected by the pattern of crown projection or the formation of gap and canopy overlapping (Wilpert and Mies 1995; Zirlewagen and Wilpert, 2001).

The proportion of the leachable pool to the total content of cations in tree foliage depends on the kind of cation and tree species (Stachurski and Zimka, 2002; Langusch et al. 2003; 
Hagen-Thorn et al, 2006). The soft beech foliage is more susceptible to leaching processes especially in the cases of $\mathrm{Mg}$ and $\mathrm{K}$ comparing to spruce foliage (Rothe et al. 2002a).

In spruce stands stemflow is of minor importance for water input to the soil surface while in a beech stand it can make up to $20 \%$ of total precipitation which may create a special circular micro site around the trunk (Nihlgård, 1970; Benecke, 1984; Koch and Matzner, 1993; Change and Matzner, 2000).

In a forest containing beech and spruce trees, the lower rates of interception and higher amount of stemflow by beech trees comparison to spruce trees will lead to an increase in total water reaching in the forest floor of the mixed stand compared with the spruce monoculture (Benecke,1984; Rothe,1997). 
Tab.1: Comparison of mean annual water and element fluxes via throughfall in pure beech and in pure spruce stands under the same site conditions from different references.

\begin{tabular}{|c|c|c|c|c|c|c|c|c|c|c|c|c|c|c|c|c|}
\hline & $\begin{array}{l}\text { Throughfall } \\
\text { water } \\
(\mathrm{mm})\end{array}$ & $\mathrm{pH}$ & $\mathrm{H}$ & $\mathrm{Na}$ & $\mathrm{K}$ & $\mathrm{Ca}$ & $\mathrm{Mg}$ & $\begin{array}{l}\mathrm{NH}_{4} \cdot \mathrm{N} \\
\left(\mathrm{kg} \cdot \mathrm{ha}^{-1}\right.\end{array}$ & $\begin{array}{l}\mathrm{NO}_{3}-\mathrm{N} \\
\left.\mathrm{a}^{-1}\right)\end{array}$ & $\mathrm{SO}_{4}-\mathrm{S}$ & $\mathrm{Cl}$ & DIN & $N_{\text {org }}$ & $\mathrm{N}_{\mathrm{t}}$ & DOC & Refrence \\
\hline beech & 663 & 5.7 & 0.01 & 13.7 & 9.9 & 9 & 3 & & & 14.9 & 31.2 & & & 8.5 & & Nihlghard, 1970 (South Sweden) \\
\hline spruce & 548 & 4.5 & 0.17 & 22.6 & 22.6 & 14.7 & 5.25 & & & 42 & 46.3 & & & 21.5 & & \\
\hline beech & 642 & & 0.04 & 2.8 & 21.9 & 7.6 & 2.2 & 7 & 5 & 11.5 & 8.5 & 12 & & & & $1985-1988$ \\
\hline spruce & 554 & & 0.12 & 3.7 & 15.6 & 11.4 & 2.5 & 19 & 9.7 & 21.3 & 12.4 & 28.7 & & & & Rothe et al., 2002a (Höglwald-Germany) \\
\hline beech & 624 & & 0.02 & 1.8 & 21.5 & 7.2 & 2.1 & 7.6 & 5.7 & 6.4 & 5.3 & 13.3 & 2.2 & 15.5 & 46 & 1994-1997 \\
\hline spruce & 529 & & 0.02 & 2.5 & 21.1 & 8.8 & 2.2 & 18.1 & 9.7 & 13.6 & 9.2 & 27.8 & 1.8 & 29.6 & 103 & Rothe et al., 2002a (Höglwald-Germany) \\
\hline beech & 272 & 4.23 & 0.16 & 3.8 & 10.3 & 16.5 & 2.6 & & & 27.2 & & 22 & & & & Růžička, 1994 ( Ore montains-Czech Republic) \\
\hline spruce & 540 & 3.93 & 0.63 & 6.8 & 12 & 32.9 & 4.2 & & & 62.1 & & 25.4 & & & & \\
\hline beech & 430 & & 0.41 & 6.7 & 17.9 & 23.3 & 3.3 & 12.5 & 9.4 & 31.3 & 18.7 & 21.9 & 4.3 & 26.2 & & Harste, Bredemeier, 1987 (Solling) \\
\hline spruce & 290 & & 1.1 & 7.8 & 18.8 & 27.2 & 4.2 & 14.9 & 12.6 & 57.3 & 25.4 & 27.5 & 4.5 & 32 & & Spanbeck, Bredemeier, 1987 (Solling) \\
\hline beech & 870 & 3.81 & 1.34 & 14.1 & 27.9 & 24.1 & 4 & 13.4 & 11.5 & 50 & 32.5 & 24.9 & 9.8 & 34.7 & & Bredemeier, 1988 (Solling) \\
\hline spruce & 752 & 3.38 & 3.15 & 17 & 28 & 31.4 & 4.7 & 15.5 & 15.7 & 83.9 & 38.6 & 31.2 & 9.6 & 40.8 & & \\
\hline beech & 890 & & 1.54 & 14.7 & 5.1 & 10.2 & 2.1 & 18.1 & 14.3 & 38.6 & 28.7 & 32.4 & & & & Meesenburg et al., 1995 (Solling) \\
\hline spruce & 830 & & 2.9 & 18.6 & 6.6 & 12.8 & 2.7 & 23.8 & 19.2 & 60.1 & 36.5 & 43 & & & & \\
\hline beech & 560 & 4.9 & 0.07 & 3.8 & 20 & 5.6 & 2.4 & & & 7.2 & 8.2 & 11 & & & 53 & Oulehe \& Hruška, 2005 (Ore montains-Czech Republic) \\
\hline spruce & 572 & 4.35 & 0.26 & 5.4 & 19 & 8.3 & 2.3 & & & 14 & 11 & 16 & & & 55 & \\
\hline
\end{tabular}




\section{Litterfall}

Forest canopy retains nutrients on site by storing in foliage and through the continuous input of litterfall (Prescott, 2002).The quantity and quality of litterfall in forest ecosystem is determined by stand species composition, age and density, and site condition (reviewed by Pedersen and Bille-Hansen, 1999; Rothe \& Binkley, 2001).

The foliage as the major part of litterfall consists $70-90 \%$ of average annual of litterfall in temperate forests (Pedersen and Bille-Hansen, 1999; Augusto et al., 2002). The amounts of litterfall in pure spruce and beech stands have been shown no significant differences under the same site conditions (Nihlgård, 1970; Ellenberg et al, 1986). According to a reviewed by Augusto et al., (2002) the average annual litterfall in mature beech stand is 3.5 and in spruce stand is $3.8 \mathrm{tha}^{-1} \mathrm{yr}^{-1}$.

Litter production in beech stands have been positively influenced by stand age and basal area (Lebret et al., 2001). Annual litterfall in spruce stands were negatively correlated with the current year increment and positively with the previous year increment (Pedersen and BillHansen, 1999). Temporal variation in litterfall patterns differ between beech and spruce. Major part of beech litterfall (as a deciduous tree) occur in late autumn and early winter, whereas, spruce foliage fall has no certain regularity. Although, it has been claimed that spruce litterfall after dry periods (summer drought) might be highest (Yang et al, 2005).

The differences in chemical composition of beech and spruce litterfall have been previously demonstrated by several authors. According to Augusto et al. (2002) and Borken et al. (2002) beech litter contents of higher base cations $(\mathrm{K}, \mathrm{Ca}$, and $\mathrm{Mg}$ ) compare to spruce litter, while $\mathrm{N}$ and $\mathrm{P}$ usually varied relatively little.

Admixture of European beech and Norway spruce can not only change the quality, quantity and spatial distribution of total litterfall (Rothe and Binkley, 2001), but also it can even improve the nutrient status of spruce trees (Thelin et al., 2002). Thelin et al., (2002) found higher concentration of $\mathrm{K}$ and $\mathrm{P}$ in the spruce needles from spruce tree growing in mixed spruce-beech stands compare to the needles from pure spruce stand.

The spatial pattern of foliar litterfall is related to wind velocity and the weight of litter materials (Lebert et al., 2001). In a mixed beech and spruce stand, the higher mobility of beech leaves can result in different spatial distribution of litterfall (Rothe and Binkeley, 2001). 
Thus, the different patterns of foliage fall and associated nutrients which can be related to canopy composition may create fine spatial scale of soil nutrient distribution.

\subsection{Canopy composition and fine roots}

Fine roots are the first functional parts of trees for reacting to change in the nutrient supply of forest soils (Persson et al., 1998). Most investigations on tree roots are carried out in pure forest stand and the information about root systems in mixed stands is very rare (Schmidt, 2002; Schmidt and Kazda, 2002; Bolte and Villauneva, 2006). The activity and distribution of fine roots in the forest floor and top mineral soil layers can be affected by nutrient and moisture supplies and also temperature (Fisher and Binkley, 2000).

Spruce is a shallow rooted species but beech trees tend to develop their roots in deeper soil layers (Köstler et al., 1968; Vogt et al., 1996). Hence, beech takes up more water and nutrients from the subsoil (Augusto et al, 2002) and spruce meets its nutrient demands in the forest floor and the top mineral soil (Göransson et al., 2006). In easily penetrable soil, spruce may also show a deeper vertical distribution (Puhe, 2003). By contrast beech fine root density may be high in the topsoil of nutrient poor sites (Schmid and Kazda, 2002). Furthermore soil solution chemistry is influencing root development. For instance base cation to $\mathrm{Al}$ (BC/Al) molar ratios below 1 limits the root growth and distribution of spruce especially within upper soil layers (Ulrich, 1971; Mc-Cormick and Steiner, 1978; Augusto and Ranger, 2001; Oulehle and Hruska, 2005).

Changes in water and nutrient availability, chemical properties of soil and soil solution and soil micro-environmental condition under different canopies may result in spatial varieties in fine root density, growth and vitality. Thus, high density of fine root in nutrient rich spots and low density or no root biomass in nutrient poor spots may cause spatial variability in soil and soil solution chemistry (Ritter et al., 2005). Puhe (2003) stated that the fine root density beneath the spruce canopy exhibit high spatial heterogeneity especially on nutrient poor soils. He claimed that due to the high spatial variability of water and elements fluxes via throughfall, the fine root density increase with distance from tree trunk toward the crown periphery.

A new vertical stratification of root systems occurs in mixed beech and spruce stands as the result of belowground interaction between those species. According to Rothe (1997), Schmid 
(2002), Schmid and Kazda (2002), spruce trees tend to develop its root systems more superficially in mixed beech-spruce stands compared to monocultures; in contrast, beech roots distribute their maximum abundance in deeper layers.

Schmidt (2002) demonstrated that site condition also may change the spatial pattern of fine roots in beech-spruce mixed stand. In a nutrient rich site he found that beech fine root exhibit maximum density in 20-25 cm depth whereas in a nutrient poor site both species showed maximum fine root density in the first $10 \mathrm{~cm}$ of soil.

Because of more variability in canopy composition, the spatial heterogeneity in soil nutrient and water supplies may cause higher uneven distribution of fine roots in mixed spruce-beech stands comparing to pure ones. Cheussom (2004), for instance, reported the higher fine root densities of spruce within the stemflow zone close to the beech trunks (under the beech canopy) in a mixed beech-spruce stand compared to under the spruce canopies.

The shallower root system of spruce and higher competitive ability of beech in belowground in mixed stands (Rothe, 1997; Schmid, 2002) may result in increasing sensibility of spruce species to drought stress comparing to spruce in a monocultures (Bolt and Villauneva, 2006). The complementary rooting patterns of spruce and beech trees may affect positively on stand stability and also exploitation of nutrients from subsoil (Schmid and Kazda, 2002). The extraction of nutrients usually by beech trees from deeper soil layer so called "Nutrient Pump Effect" (Rothe, 1997) can just take place in soils whose sub soil layers have high nutrient pool and no limitation to root penetration (Bolte and Villauneva, 2006). But because of a lot of unknown interactions in mixed beech-spruce stand, the available knowledge about the pumping effect is not enough to generalization.

Fine root biomass for both spruce and beech species in a mixed stand were reported lower than pure stands (Rothe, 1997; Schmid, 2002, Villaunueva, 2003). According to Majdi (2004) fine roots represented a large portion of the below ground biomass e.g., ca. 30-40\% more than annual needle litterfall in pure spruce stand in southern Sweden. The turnover of fine root as a critical source of nutrient (Persson, 1979; Gill and Jakson 2000) can recycle the same amount of $\mathrm{N}, \mathrm{P}, \mathrm{K}$, and $\mathrm{S}$ as aboveground litterfall in temperate forests (Burke and Raynal, 1994). Therefore this part of trees has an important effect on soil chemical and biological properties. 
Forest canopy as a source of changes in water and nutrient inputs has a clear influence on chemical properties of soil solution (Wilpert and Mies, 1995). As will be discussed in the later parts of this section, the growth and distribution of fine root are mostly controlled by soil and soil solution chemistry. Hence, canopy composition can indirectly determine the root characteristics (Savin et al., 2000).

\subsection{Canopy composition and soil chemistry}

The forest floor reflects the relationship between the rate of litter production and decomposition (Olson, 1963). The forest floor mass and chemical properties may differ between various tree species growing on the same soil mainly due to the differences in nutrient inputs (Gower and Son, 1992; Muys et al, 1992). In general, the production of high organic acids (and lower soil $\mathrm{pH}$ ) has been noted under tree species whose litter is relatively recalcitrant to the decomposition process (Konova, 1966).

Spruce trees tend to produce organic matters with relatively higher molecular weight and build up a relatively thicker, acidic and compact forest floor compared with beech trees (Binkley and Valentine, 1991; Versterdal and Rasmussen, 1998; Rothe et al, 2002a). Thus, the thickness of the organic layer under spruce may indicate that the cycling of nutrients is blocked or delayed (Berger et al., 2006) but the mechanisms which are responsible for the accumulation of organic matter in spruce stands remains little understood (Albers et al., 2004).

Several studies have also confirmed the acidifying effect of spruce on top mineral soil layers as well as lower levels of base saturation and higher levels of $\mathrm{Al}$ and Fe (Son and Gower, 1992; Ranger and Nys, 1994; Hagen-Thorn et al, 2004). In Sweden, Folkeson (1996) claimed that the accumulation of base cations in biomass and soil exchangeable pool under spruce were more than beech stands because of enhancement of mineral weathering by spruce trees. Berger et al. (2006) also suggested that in the mixed spruce-beech stand, the acidifying effect of spruce litter may accelerate the mobilization of calcium in the upper mineral soil.

The heterogeneity of forest soil chemistry might also be related to the distance from the tree stem, especially in beech forest, which in part may be due to the spatial patterns of throughfall or stemflow and rooting systems (Koch and Matzner, 1993). Under spruce stands, high concentrations of calcium, magnesium and potassium are related to leaching of these elements 
from the foliage via throughfall close to the stems (Ulrich, 1971). In addition, canopy composition and structure can influence the light reaching the soil, then modify decomposition and humus formation and consequently affect on forest floor and upper mineral soil characteristics (Epron et al, 2004; Aubert et al, 2006). In the mixed spruce-beech stands litter layers are significantly thinner and topsoil $\mathrm{pH}$ as well as base saturation is significantly higher than in the spruce monocultures (Rothe, 1997).

Vertical distribution of elements especially in the upper soil layers may be influenced by canopy composition (Chodak et al., 2002). For instance, carbon input by litterfall and roots into different soil horizons has a marked effect on the vertical distribution of $\mathrm{C}$ and $\mathrm{N}$ storages (Berger et al, 2002). Chodak et al. (2002) described vertical concentration of major elements in the forest floor and upper mineral soil under beech, spruce and mixed stands with an exponential equation. They found the same pattern of vertical element distribution under different canopy composition.

The influence of canopy complexity in mixed species forests on spatial heterogeneity of above and below-ground element inputs may consequently lead to spatial variability of the forest floor and the upper mineral soil chemistry (Rothe et al, 2001; Prescott, 2002).

\subsection{Canopy composition and soil solution chemistry}

The soil solution as the main interface between soil biota, minerals and organic matter plays an important role in biogeochemical cycles in forest ecosystems (Augusto and Ranger, 2001). The chemical composition of the soil solution is often influenced by chemical, physical and biological properties of soils and also by the chemical composition of infiltration water (Mulder and Cresser, 1994). For instance, $\mathrm{N}$ deposition may enhance nitrification which may lead to soil acidification, nitrate and cation leaching, Al mobilisation and root damage (Canol et al., 1997). Differences between tree species in nutrient and element inputs via hydrological pathways (throughfall and stemflow), litterfall and biochemical processes in the forest floor and soil, may be reflected in spatial and temporal variability of soil solution chemistry (Manderscheid and Matzner, 1995; Rothe et al, 2002a).

According to Gessler et al, (1998), Rothe et al., (2002b) and Oulehle \& Hruška (2005) the pH and ionic strength of the soil solution were higher and the base cation to Al molar ratios were lower under spruce canopy compare to under beech canopy. The higher rate of rainfall interception by spruce canopy compared with beech (Augusto and Ranger, 2001) lead to less 
moisture in soil and may tend to concentrate soil solution. Nitrate, sulphate, and base cation leaching were reported to be higher in spruce stands comparing to beech stands (Rothe et al, 2002b). Since N storage in soils (Rothe, 1997) and N uptake (Rennenberg et al, 1998) were similar in both stands, differences in dry deposition or in the rates of nitrification in the forest floor (Rothe et al, 2002b) can explain differences of $\mathrm{NO}_{3}{ }^{-}$concentrations in the soil solution under the root zone in spruce and beech stands. Lower nitrogen leaching under beech may also result from higher output of gaseous nitrogen compounds compared to spruce (Gashe and Papen, 1999). In spruce stands leaching of $\mathrm{SO}_{4}{ }^{2-}$ was higher than throughfall input (Rothe et al, 2002; Oulehle \& Hruška, 2005) because the soil under spruce might act as a source of this element (Wilpert and Mies, 1995).

A part of spatial heterogeneity in soil solution chemistry depends on proximal and distal areas to tree stems (Wilpert and Mies, 1995; Rothe et al., 2002 b). For instance, stemflow under beech canopy and spatial variation of throughfall water and element fluxes under spruce canopy may create obvious spatial heterogeneity in soil solution chemistry (Koch and Matzner, 1993). Based on their study, Koch and Matzner (1993) stated that, increasing in $\mathrm{K}^{+}$ and $\mathrm{NO}_{3}{ }^{-}$concentrations close to the stem under beech canopy might be due to the effect of stemflow. They also claimed that under spruce canopy, a significant increase in $\mathrm{Ca}^{2+}, \mathrm{K}^{+}$and $\mathrm{NH}_{4}{ }^{+}$, and decrease in $\mathrm{NO}_{3}{ }^{-}$concentrations next to the stem may be related to the pattern of throughfall. Moreover, the accumulation of humus close to the stems of spruce which cause different mineralisation rates may be responsible for the spatial patterns of soil solution chemistry in the case of $\mathrm{K}^{+}$and C contents (Friedrich, 1992; Augusto and Ranger, 2001).

In a mixed beech - spruce stand, the more complexity in canopy creates more variability in spatial distribution of nutrient and water inputs. It would be expected to see greater spatial heterogeneity of soil solution chemistry in mixed spruce- beech stand compare to pure beech and spruce stands.

\subsection{Canopy composition and litter decomposition}

The decomposition of tree litter is the basic process in the nutrient dynamics and vital to productivity of forest ecosystem (Didham, 1998). This process is affected generally by:

- Litter quality, like N, P, Mn, Ca and lignin contents, C/N and lignin/N ratios (Berg et al., 1986; Aber et al, 1990; Berg, 2000) 
-Microclimatic conditions in which decomposition take place (like temperature, moisture within a forest floor and light distribution which dependent on tree canopy) as the major affecting factors at least in the early stage of litter decay (Vogt et al., 1983;b Meentemeyer and Berg, 1986; Loranger et al., 2001)

- Biomass, diversity and activity of decomposing organisms (Elliott et al, 1993; Cornelissen, 1996). As described by Wilkinson \& Anderson (2001) and Prescott (2002) all of those factors are related directly and indirectly to the forest canopy. Versterdal (1999) believed that in addition to the mentioned factors, decomposition of beech leaves are also influenced by soil chemistry, whereas the decomposition of spruce litter was less affected by soil quality.

The decomposition of litter may be divided into two phases. In the first phase soluble substances and non-lignified substrates (cellulose and hemicelluloses) are decomposed. In this stage the decay of dissolved organic material and leaching of nutrient occurs (Joergensen and Meyer, 1989). The mass loss is controlled by the concentrations of nutrients which are limiting the microbial activity (N, P and $\mathrm{S}$ ) and also the concentration of soluble material which are easily degradable. In the later phase, the lignin and lignified celluloses remain. Therefore, the decomposition rate of litter in the second stage is ruled by the rate of mass loss of lignin (Berg, 1986). Lignin is a major recalcitrant polymer of plant cells and only a few organisms (like white-rot fungi) are able to degrade it (Heim and Frey, 2004).

Albers et al. (2004), Heim and Frey (2004) and Sarilyildiz et al. (2005) found that in the early stage of decomposition, spruce needles decompose more rapidly than beech leaves. In contrast, Vesterdal (1999) and Prescott et al, (2000) reported that in spite of the initially faster decomposition of beech leaves, there is a little difference between litter decay rates of these two tree species. In addition to the litter quality, abiotic leaching of soluble substances can influence litter decomposition rate in the early stage after litterfall in temperate forest (Heim and Frey, 2004).

Differences in mass loss and mineralisation of litter in mixed stands are often related to litter quality (Mellio et al, 1982; Gower and Son, 1992; Scott and Binkley, 1997). According to Berg and Staaf (1981) the accumulation and release rates of nutrients like N, show a linear relationship with litter mass loss.

Beech leaves consist of more favourable sources for micro-organisms than spruce needles (Scheu et al., 2003, Albers et al., 2004). The litter layer under beech is considerably moister 
than under spruce (Augusto and Ranger, 2001). Hence, the microbial biomass and their activities might be more in the beech forest floor compared with in the spruce forest floor. On the other hand, under the spruce canopy compare to beneath beech canopy, the higher fluxes of inorganic $\mathrm{N}$ and other nutrients via throughfall which are available to decomposer may decrease the rate of litter decomposition (Fogg, 1988). Those possible reasons can explain why litter decomposes faster under beech or mixed canopies compared with under the canopy of spruce (Sarilyildiz et al, 2005). Therefore, the spatial patterns of through- and litterfall in a mixed stand can be the important causes for creating the spatial pattern of decomposition. At the same time, the spatial patterns of differences in biophysical factors beneath different parts of the canopy (Wilkinson and Anderson, 2001) and also in root distributions (Riha et al.,2001) can have a significant influence on decomposer communities and consequently on decomposition rates.

The nitrogen dynamic within decomposing litter can be complicated by simultaneous release of $\mathrm{N}$ from the litter and incorporating of $\mathrm{N}$ to the litter from external sources (Gebauer et al., 2000). Hence, the increasing of $\mathrm{N}$ content is often occurred in litter during the first stage of litter decomposition (Berg, 1986; Gebauer et al., 2000). Fogg (1988) suggested the following mechanisms which affect litter decomposition after $\mathrm{N}$ addition i) changing the community of decomposers, ii) suppression effect of ammonia to produce enzymes required for lignin degradation and iii) the reaction of amino compound with organic matter to form recalcitrant materials.

Litter composition can influence decomposition rates (Finzi and Canham, 1998; Gartner and Cardon, 2004). The mixed litter showed higher decay rates than individual beech and spruce litters in both pure and mixed stands (Rothe and Binkley, 2001; Sarilyildiz et al., 2005). The rapid decomposition of high quality litter may produce high $\mathrm{N}$ availability that may stimulate the decomposition of lower quality litter by allowing the transfer of nutrient between litters, leading to a more rapid utilization of carbon substrates (Chapman et al., 1988). The greater sources variety in a mixed species litter may encourage nematode population and consequently the rates of $\mathrm{N}$ mineralisation during the initial stage of leaf litter decomposition (Finzi and Canham, 1998). Thus, the greater productivity of mixed-species forests has been attributed in part to greater nutrient availability resulting from enhancement of decomposition rates of mixed litters (Perry et al., 1987; Comeau, 1996; Ferrari, 1999; Gartner and Cardon, 2004). 
The capability of canopy composition to vary the nutrient inputs and micro-climatic conditions in the forest floor of a mixed stand may be one of the main reasons to cause spatial heterogeneity in decay rates. Hence, when a standard litter (the same litter type) is incubated under different parts of the canopy in a mixed beech-spruce stand, different decay rates might be measured with respect to the canopy composition.

\subsection{Canopy composition and soil respiration}

In terrestrial ecosystems, soils as the largest reservoir of carbon play a pivotal role to change the concentration of atmospheric $\mathrm{CO}_{2}$ (Johnson and Curtis, 2001). Any change in soil properties due to different forest management methods can affect soil $\mathrm{C}$ pools and this can have considerable impacts on the carbon budget of the atmosphere.

The measurement of soil $\mathrm{CO}_{2}$ fluxes may provide a useful parameter to compare differences between forest ecosystems (Borken et al., 2002). Carbon dioxide is released from soil belowground through autotrophic respiration which originate from root and mycorrhizae activities and heterotrophic respiration or microbial respiration (Brumme, 1995; Bowden et al., 1993; Buchmann, 2000).

Tree species is considered to affect soil respiration by influencing soil microclimate, the quantity and quality of above and below ground organic matter and the rate of root respiration (Borken and Beese, 2005).

Soil respiration is known to exhibit a high spatial and temporal variability (Tewary et al., 1982; Fang et al., 1998; Xu and Qi, 2001; Borken et al., 2002). A set of combined parameters like live and dead biomass, soil properties (Fang et al., 1998; Søe \& Buchmann, 2005) and the contents of major nutrients like $\mathrm{C}, \mathrm{N}, \mathrm{P}$ and $\mathrm{Mg}$ that control microbial activities (Xu and $\mathrm{Oi}$, 2001; Hanson et al, 2003) may cause the spatial heterogeneities in $\mathrm{CO}_{2}$ efflux. The soil respiration rates in coniferous forests are usually lower than those in broad-leaved forests located on the same soil types (Weber, 1990). Comparative studies in pure and mixed beech and spruce stands by Borken and Beese (2005) showed that the total soil respiration was higher in pure beech stands compared with pure spruce stands and intermediately in mixed spruce beech stands. 
Available data show that the total soil respiration negatively correlated $\left(r^{2}=0.88\right)$ with $\mathrm{C}$ stock in O-horizons in beech and spruce stands (Fig. 2). The accumulation of $\mathrm{C}$ especially refractory $\mathrm{C}$ in organic layers may provide unfavourable condition for microbial and root activities. Hence, total soil respiration decrease with increasing $\mathrm{C}$ pools in organic layers (Tewary et al., 1982). Whereas, Borken and Beese (2005) claimed that the O horizon respiration rates was not correlated with $\mathrm{C}$ stocks of organic layers. The incorporation of fine root in $\mathrm{O}$ horizons and also the influence of the forest floor layer to maintenance soil moisture and temperature could not be separated from $\mathrm{C}$ stocks in this correlation. Contrary, some authors believe that more than $60 \%$ of soil respiration originated from mineral horizons (explained by Buchmann, 2000).

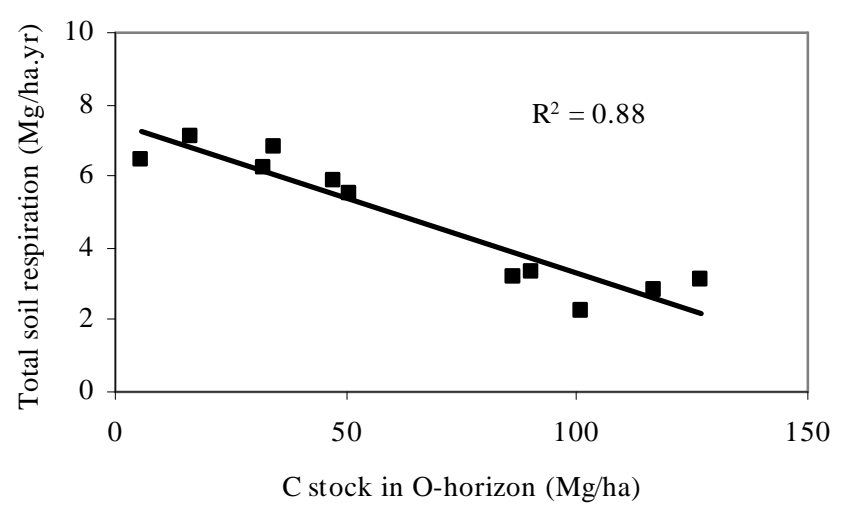

Fig.2: Relationship between soil respiration and $\mathrm{C}$ stock in $\mathrm{O}$ horizon in different stands $(\mathrm{n}=11)$.

There are several methods to estimate the contributions of different sources in releasing $\mathrm{CO}_{2}$ from the soil in different forest ecosystem. One of the common approaches to estimate root associated $\mathrm{CO}_{2}$ production is a conceptual model named TBCA (Total Belowground Carbon Allocation) which has been proposed by Raich and Nadelhoffer (1989). They suggested that the total belowground carbon allocation (TBCA) could be estimate from the difference between annual rates of soil respiration and aboveground litterfall. The model assumes that the leaching losses of $\mathrm{C}$ are negligible and the stocks of organic matter, root and litter in soils are in a steady state. Therefore, TBCA equals to root respiration and root litter C decomposition. In their model, annual changes in the soil and litter stores must be small relative to soil respiration and litterfall $\mathrm{C}$ (for more details see material and method section).

The major temporal variations in soil respiration may be related to the top soil temperature and the wetting and drying of organic layers via differences in throughfall amount (Borken et 
al. 2002; Andersen et al., 2005; Borken and Beese, 2005; Borken et al. 2006). Buchmann (2000) claimed that in spruce stands, the temporal variations in soil respiration depended more in on temperature than on moisture.

According to Buchmann, (2000) the role of canopy to control soil respiration may be related to the characteristics of canopy to manage micro environmental conditions. Tewary et al. (1982) claimed that in a mixed (Oak- coniferous) forest, soil respiration rates in microhabitats beneath coniferous were lower than those beneath broad-leaved trees. They illustrated that the habitats (the area under different canopy classes) with more nitrogen and soil moisture and lesser carbon and bulk density or with higher quality litterfall showed greater respiration.

Until now, only a few studies have been investigated the soil $\mathrm{CO}_{2}$ efflux in mixed beechspruce stands (Borken and Beese, 2005). There is no information about the impact of canopy composition in a mixed spruce- beech stand to spatial variability in soil $\mathrm{CO}_{2}$ efflux. If the crowns of individual trees show the same behaviour in pure and mixed stand, one can expect to observe different rates of soil respiration under the crown of spruce and beech trees growing in a mixed stand. Therefore, in a mixed stand, the soil respiration can be used as a good indicator to distinguish the created conditions or micro-sites under different parts of canopy.

Tab.2: Mean annual litterfall, soil respiration and O-horizon C stock in different references.

\begin{tabular}{|c|c|c|c|c|}
\hline Stand type & $\begin{array}{c}\text { Annual } \\
\text { litterfall } \\
\text { (Mg C/ ha.yr) }\end{array}$ & $\begin{array}{c}\text { O-horizon } \\
\text { C stock } \\
\text { (Mg C/ ha) }\end{array}$ & $\begin{array}{l}\text { Annual soil } \\
\text { respiration } \\
\text { (Mg C/ ha.yr) }\end{array}$ & Refrences \\
\hline beech & 1.9 & 5.6 & 6.5 & Elberling \&Ladegaard-Pedersen \\
\hline spruce & 2.1 & 47.3 & 5.9 & (2005)-Denemark \\
\hline spruce & 1.9 & 117 & 2.8 & Lytle \& Cronan (1998)-USA \\
\hline Spruce & 2.8 & 50.7 & 5.5 & Borken \& Beese (2005)-Solling \\
\hline Mixed & 2.9 & 32.3 & 6.2 & $30 \%$ beech \\
\hline Mixed & 2.7 & 34.2 & 6.8 & $70 \%$ beech \\
\hline Beech & 3.1 & 16.3 & 7.1 & \\
\hline Beech & & & 6.8 & Brumme \& Beese (1992)-Solling \\
\hline Beech & 4.09 & 90 & 3.3 & Borken et al.(2002)-Solling \\
\hline Spruce & 3.96 & 101 & 2.2 & \\
\hline Beech & 4.34 & 127 & 3.1 & Unterlüßt \\
\hline Spruce & 3.51 & 86 & 3.2 & \\
\hline
\end{tabular}




\section{Hypothesis}

Tree composition affects ecological properties on a small spatial scale (Zinke, 1962). In a mixed forest the heterogeneity in canopy composition may create different representative structural units (Wilpert and Mies, 1995) with different ecological characteristics, fluxes of water, nutrients and energy. The research on nutritional interaction in mixed forest could thus greatly benefit from studies on a small spatial scale where actual interaction between different trees takes place (Rothe and Binkley, 2001).

The complexity of the canopy structure of a mixed forest stand makes it difficult, however, to apply the methods commonly used to describe small-scale spatial patterns of water and nutrient inputs in monoculture stands. Therefore, in contrast to other investigations, where the spatial patterns were described in relation to the distances from neighbouring trees or foliage density (Beier et al., 1993; Staelens et al., 2006), different types of canopy compositions (canopy classes) were used to identify the variability of input fluxes, soil and soil solution properties, litter decomposition and soil respiration. In order to see whether the mixed forest stands with different proportions of spruce and beech might show similar patterns of nutrient inputs and status under different canopy categories; two widely contrasting cases (a stand greatly dominated by beech and a stand greatly dominated by spruce) were investigated. The canopy of each plot was classified into four categories: pure spruce, mixed spruce and beech, pure beech and gap.

The main hypothesis to be tested in this study was that in a mixed forest the heterogeneity in canopy composition may create different micro-sites with different biogeochemical characteristics. The following questions were addressed in this thesis:

i) The four different canopy classes will show different nutrient inputs due to differences in amounts and chemistry of litterfall and throughfall and these differences will be similar in two widely contrasting types of mixed beech and spruce stands growing at the same site.

ii) The organic and mineral soil layers under different canopy classes in each plot show the different chemical properties.

iii) Soil solution chemistry is affected by canopy composition. 
iv) The decomposition and nitrogen turnover of an incubated standard litter (spruce needle) within forest floor in a litterbag experiment show different rates under different canopy classes.

v) The soil respiration rate as an indicator of soil microbial and root activity is affected by canopy composition.

The results of nutrient inputs (throughfall and litterfall) presented here were re-compiled in the form of an article entitled "Canopy composition as a measure to identify patterns of nutrient input in a mixed European beech and Norway spruce forest in central Europe" has been accepted to publish in the European Journal of Forest Research. The results of other parts will also be edited and as soon as will be submitted for publication. 


\section{Material and Methods}

\subsection{Site description}

The study was conducted in Solling Forest, in central Germany. The site is located approximately $50 \mathrm{~km}$ north-west of Göttingen in Lower Saxony $\left(51^{\circ} 47^{\prime} \mathrm{N}\right.$ and $\left.9^{\circ} 37^{\prime} \mathrm{E}\right)$ at an altitude of 250-300 m. The climate at Solling can be described as sub-oceanic, with a mean annual air temperature average of $6.5^{\circ} \mathrm{C}$ and total annual precipitation of $1090 \mathrm{~mm}$. The soil type at the experimental site was an acid dystric cambisol (FAO) developed on triassic sandstone, covered by a loess layer. Soil texture is dominated by silty loam. Morphological humus forms are typical moder.

The experimental stand is a mixture of European beech (Fagus sylvatica L.) and Norway spruce (Picea abies (L.) Karst.) trees (Tab. 3). Two previously equipped plots (Chessom, 2004) used for present investigation. The area of each plot covered about $300 \mathrm{~m}^{2}$. The plots are described as follow: the beech-dominated plot (BDP) where a central spruce tree is surrounded by eight beech trees (Fig. 3) and the spruce-dominated plot (SDP) where a centred beech tree is surrounded by one beech and nine spruce trees (Fig. 4). Most parts of spruce dominated plot (SDP) and some parts of the beech dominated plot (BDP) were covered with the patches of ground vegetations and regeneration, respectively. The distance between two plots was about $300 \mathrm{~m}$.

Tab.3: Stand characteristics of the beech (BDP) and spruce (SDP) dominated plot.

\begin{tabular}{|c|c|c|c|c|c|c|c|c|}
\hline \multirow[t]{2}{*}{ Plot } & \multirow{2}{*}{$\begin{array}{l}\text { Tree species } \\
\text { (number of } \\
\text { trees) }\end{array}$} & \multirow[t]{2}{*}{$\begin{array}{l}\text { DBH } \\
\mathrm{cm}( \pm \mathrm{SD})\end{array}$} & \multirow[t]{2}{*}{$\begin{array}{l}\text { Height } \\
\mathrm{m}( \pm \mathrm{SD})\end{array}$} & \multirow[t]{2}{*}{$\begin{array}{l}\text { Basal Area } \\
\mathrm{m}^{2}( \pm \mathrm{SD})\end{array}$} & \multicolumn{4}{|c|}{$\begin{array}{l}\text { Canopy area } \\
\mathrm{m}^{2}(\text { percent } \%)\end{array}$} \\
\hline & & & & & spruce & mixed & beech & gap \\
\hline$B D P$ & & & & & $11(4)$ & $17(6)$ & $231(81)$ & $27(9)$ \\
\hline dominating tree & beech (8) & $42.8(8.9)$ & $28.6(1.8)$ & $0.34(0.1)$ & & & & \\
\hline admixed tree & spruce (1) & 61.4 & 32.8 & 0.48 & & & & \\
\hline$S D P$ & & & & & $157(56)$ & $45(16)$ & $51(18)$ & $28(10)$ \\
\hline dominating tree & spruce (10) & $67.4(6.8)$ & $38.2(3.3)$ & $0.53(0.1)$ & & & & \\
\hline admixed tree & beech (2) & $44.2(15.7)$ & $25.6(5.6)$ & $0.35(0.1)$ & & & & \\
\hline
\end{tabular}



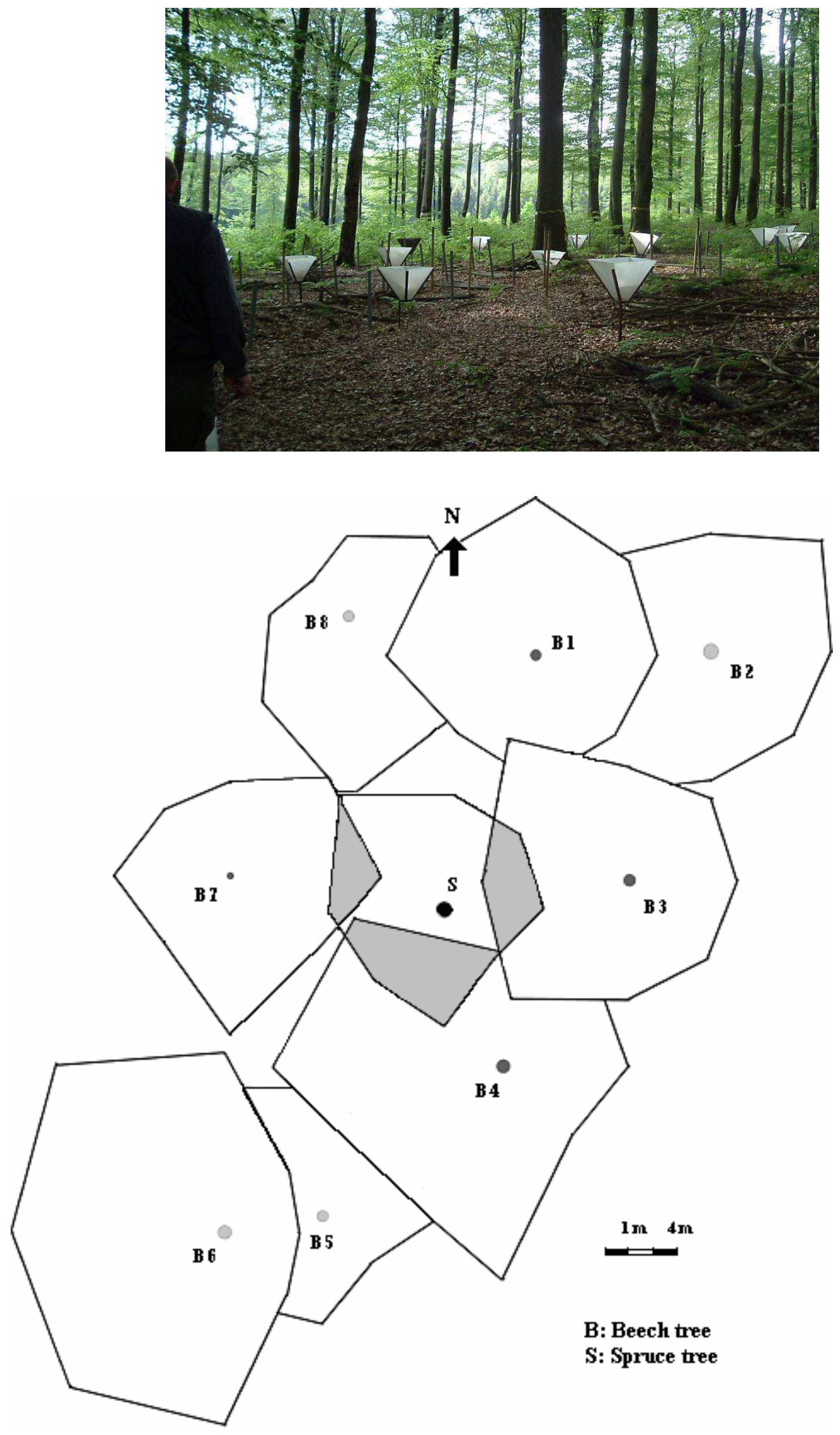

Fig. 3: The beech dominated plot (BDP). 

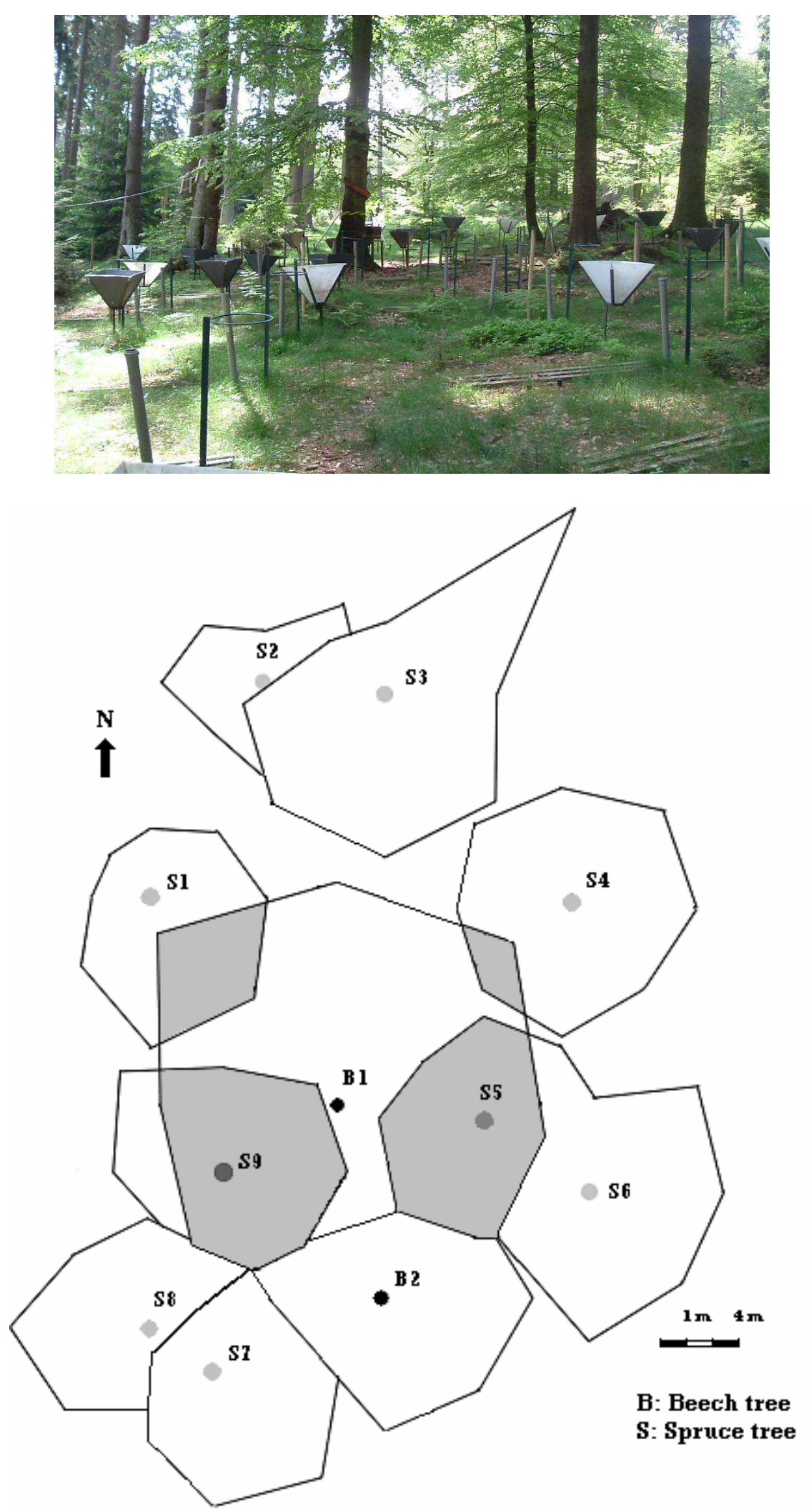

Fig.4: The spruce dominated plot (SDP). 


\subsection{Data collection, field measurements and chemical analysis}

\subsubsection{Throughfall}

In order to collect throughfall, three gauges $(\varnothing=8 \mathrm{~cm})$ were randomly installed in the area under each canopy class approximately $1 \mathrm{~m}$ above forest floor at fixed positions from May 2005 to July 2006. The gauges were placed in the middle of the crown projection and the opening area of the gap to avoid edge effects.

Sampling was carried out 1-2 times a month and samples were combined proportionally to water fluxes for monthly samples for analysis. Sampling collectors were replaced by cleaned ones at the end of each month. In snow periods, buckets $(\varnothing=25 \mathrm{~cm})$ replaced the rain collecting gauges. After collection, samples were filtered and stored at $4{ }^{\circ} \mathrm{C}$ prior to analysis.

Chemical analysis of throughfall water for $\mathrm{SO}_{4}{ }^{2-}, \mathrm{Na}^{+}, \mathrm{K}^{+}, \mathrm{Ca}^{2+}, \mathrm{Mg}^{2+}$ and $\mathrm{Mn}^{2+}$ was carried out by the Inductive-Coupled Plasma Atomic Emission Spectroscope technique (ICP-AES, Spectroflame, Spectro Analytical Instruments, Kleve, Germany). The contents of $\mathrm{NH}_{4}{ }^{+}, \mathrm{Cl}^{-}$, and $\mathrm{NO}_{3}{ }^{-}$were determined by using continuous flow injection colorimetry (Cenco/Skalar Instruments, Breda, The Netherlands). DOC was measured by dry combustion at $680{ }^{\circ} \mathrm{C}$ using a TOC-5050 Shimadzu organic C analyser (Shimadzu Europa, Duisburg, Germany). The pH was measured in the laboratory with a Microprocessor pH / Ion Meter PMX 3000.

\subsubsection{Litterfall}

Each plot was equipped with 18 litter traps $(0.5 \times 0.5 \mathrm{~m})$ made of plastic and perforated at the bottom for water drainage. The number of litter traps in the area under each canopy class was 4 , 4, 6 and 4 under spruce, mixed, beech canopies and in the gap canopy classes, respectively, in each plot. The traps were distributed randomly and raised about $0.5 \mathrm{~m}$ above the forest floor at fixed positions. Litterfall was collected monthly from May 2005 to July 2006, except from December 2005 to February 2006 (one sampling), because of heavy snow and ice layers in the litter traps.

The collected litter was oven-dried at $60^{\circ} \mathrm{C}$ immediately to constant weight (48 - $\left.72 \mathrm{~h}\right)$. The dried materials were sorted manually into the following compartments: leaves, needles, beech 
branches, spruce branches, a fraction of residual materials, which consisted of bud scales, seeds, seed shells and other fine debris. Thereafter the monthly weight of each fraction in each trap was registered. The materials of animal origin were not included in the subdivided fractions.

Chemical analysis was applied on sub-samples of the monthly litter samples, but only for the leaf and needle fraction. Samples were prepared by grinding the litter to a fine powder and subsequently digesting it with $2 \mathrm{ml}$ of $\mathrm{HNO}_{3}$ in Teflon digestion bombs $\left(5 \mathrm{~h}, 170{ }^{\circ} \mathrm{C}\right.$; for further description see also Heinrichs H. 19869). After digestion the concentration of major cations $\left(\mathrm{Na}^{+}, \mathrm{K}^{+}, \mathrm{Ca}^{2+}, \mathrm{Mg}^{2+}, \mathrm{Mn}^{2+}\right)$ and total sulphur $\left(\mathrm{S}_{\mathrm{t}}\right)$ were determined by the Inductive-Coupled Plasma Atomic Emission Spectroscope technique (ICP-AES, Spectroflame, Spectro Analytical Instruments, Kleve, Germany). The values were recalculated on the absolute dry weight (105 $\left.{ }^{\circ} \mathrm{C}\right)$ basis, which was determined on separate sub-samples. Total nitrogen $\left(\mathrm{N}_{\mathrm{t}}\right)$ and carbon $\left(\mathrm{C}_{\mathrm{t}}\right)$ were determined by a $\mathrm{C} / \mathrm{N}$-analyser (CHN-O-Rapide, VarioEL, Elementar, Germany).

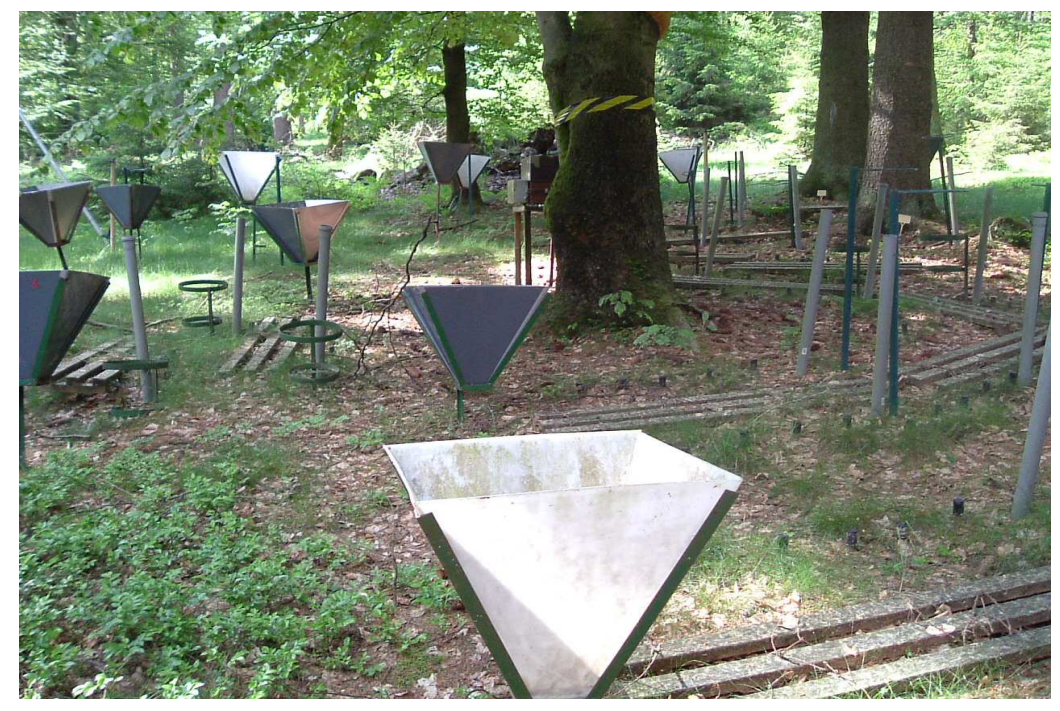

Fig.5: Litter traps installed under the central beech tree in the spruce dominated plot (SDP).

\subsubsection{Forest floor and mineral soil}

According to the given canopy projection, the area under each of the four canopy class was identified as a subplot (i,e, four subplots per plot). The soil sampling was carried out in June and July 2005 with coring method (cylindrical steel columns, $7 \mathrm{~cm}$ diameter and $40 \mathrm{~cm}$ height). The sampling points were distributed randomly within each subplot. The core samples were taken from organic horizon up to $40 \mathrm{~cm}$ depth of mineral soil with 4 replicates per subplot. The undisturbed soil cores were kept in tight plastic at $4{ }^{\circ} \mathrm{C}$ until handling in the 
laboratory. The organic part of soil samples were divided into $\mathrm{O}_{\mathrm{L}+\mathrm{F}}, \mathrm{O}_{\mathrm{H}}$ sub-samples. The mineral parts were sliced into sub-samples based on following depth interval: 0-2.5, 2.5-5, 5$10,10-20$ and $20-40 \mathrm{~cm}$. Samples from the humus layers were oven-dried at $60^{\circ} \mathrm{C}$, the mineral soil samples were dried at $40^{\circ} \mathrm{C}$ to constant weight $(48-72 \mathrm{~h})$. Thereafter, the weights of the samples were registered. All samples were grinded to a fine powder and sieved through a mesh size of $2 \mathrm{~mm}$ before analysis.

The organic samples were digested with $2 \mathrm{ml}$ of $\mathrm{HNO}_{3}$ in teflon digestion bombs $\left(5 \mathrm{~h}, 170{ }^{\circ} \mathrm{C}\right.$, Heinrichs, 1989). The cations and total $S\left(S_{t}\right)$ were measured with the inductive-coupled plasma atomic emission spectroscope technique (ICP-AES, Spectroflame, Spectro Analytical Instruments, Kleve, Germany). Total $\mathrm{N}\left(\mathrm{N}_{\mathrm{t}}\right)$ and $\mathrm{C}\left(\mathrm{C}_{\mathrm{t}}\right)$ were determined by a $\mathrm{C} / \mathrm{N}$-analyser (CHN-O-Rapide, VarioEL, Elementar, Gemany). All given element concentrations are related to the absolute dry weight at $105^{\circ} \mathrm{C}$.

For mineral soil samples, exchangeable cations $\left(\mathrm{Na}^{+}, \mathrm{K}^{+}, \mathrm{Ca}^{2+}, \mathrm{Mg}^{2+}, \mathrm{Fe}^{3+}, \mathrm{Mn}^{2+}\right.$ and $\left.\mathrm{Al}^{3+}\right)$ were determined after percolating of samples with $1 \mathrm{M} \mathrm{NH}_{4} \mathrm{Cl}$ (Meiwes et al. 1984) and by subsequent ICP- AES analysis. The $\mathrm{pH}$ values were measured with a digital $\mathrm{pH}$-meter (WTW GmbH Weilheim, Germany) in $1 \mathrm{~mol} \mathrm{~L}^{-1} \mathrm{KCl}$ solution $(1: 2,5)$. Cation exchange capacity (CEC) was calculated as the equivalent sum of exchangeable cations and $\mathrm{H}^{+}$. The base saturation was calculated as the equivalent sum of base cations $\left(\mathrm{Na}^{+}, \mathrm{K}^{+}, \mathrm{Ca}^{2+}, \mathrm{Mg}^{2+}\right)$ as a percent of CEC.

\subsubsection{Soil solution}

Ceramic suction lysimeters (ceramic cups with $2 \mathrm{~cm}$ diameter and $5 \mathrm{~cm}$ length) were used to extract soil solutions. The lysimeters were installed in depths of 10 and $100 \mathrm{~cm}$ of mineral soil in each subplot. Three lysimeters were placed at each depth and connected to the same collecting bottle. For each plot, a vacuum pump was applied to collect soil solutions in bottles which were placed in installed containers to keep them dark and cool. During winter, a heater was used to prevent freezing. Soil solution was sampled at monthly interval from Oct 2003 to July 2006.

The filtered $(0.45 \mu \mathrm{m})$ soil solution samples were used to analysis. The $\mathrm{pH}$ was measured in the laboratory with a digital $\mathrm{pH}$ meter (WTW GmbH Weilheim, West-Germany). Chemical analysis of solution samples for $\mathrm{SO}_{4}{ }^{2-}, \mathrm{K}^{+}, \mathrm{Ca}^{2+}, \mathrm{Mg}^{2+}$ and $\mathrm{Al}^{3+}$ were carried out by Inductive- 
Coupled Plasma Atomic Emission Spectroscope technique (ICP-AES, Spectroflame, Spectro Analytical Instruments, Kleve, Germany). The contents of $\mathrm{NH}_{4}{ }^{+}$and $\mathrm{NO}_{3}{ }^{-}$were determined by using continuous flow injection colorimetry (Cenco/Skalar Instruments, Breda, The Netherlands).

\subsubsection{Litterbag technique with ${ }^{15} \mathrm{~N}$ needle litter}

The rate of litter decomposition was assessed by litterbag technique (Berg and Tamm, 1991). Needle litter was collected from roof project -Solling in April 2005. Needles were taken from a falling spruce tree which grown in an enriched plot with ${ }^{15} \mathrm{~N}$ isotope (Feng et al., 2007). The litterbags (polyethylene bags, $7 * 7 \mathrm{~cm}$, mesh $1 \mathrm{~mm}$ ) were filled with $5-10 \mathrm{~g}$ of the air-dried needles. 480 litterbags were numbered and incubated within the forest floor under different canopy classes in both plot. The litterbags ( $\mathrm{n}=5$ for 12 months) were incubated randomly in every subplot of both plots. The exact weight of each bag was registered before incubating in the field (Fig. 6).

The incubation started in May 2005 and from Jun 2005, every month 5 litterbags were collected from each subplot. Because of covering the forest floor by ice layers during the snowing period in winter (Nov 2005 to Jan 2006), the litterbags were not collected. In order to take out all incubated litterbags, the experiment prolonged to 15 months. The remaining needle material was weighted and the mass loss was determined. Since the mass loss of decomposing litter depends of litter quality and micro-site characteristics, the usage of a standard litter allows estimating the relative importance of micro-site characteristics under each kind of canopy class on decomposition rates. In this experiment, the mass loss and nitrogen turnover of standard litter incubated in forest floor layer at different subplots is only controlled by micro-environmental condition. 

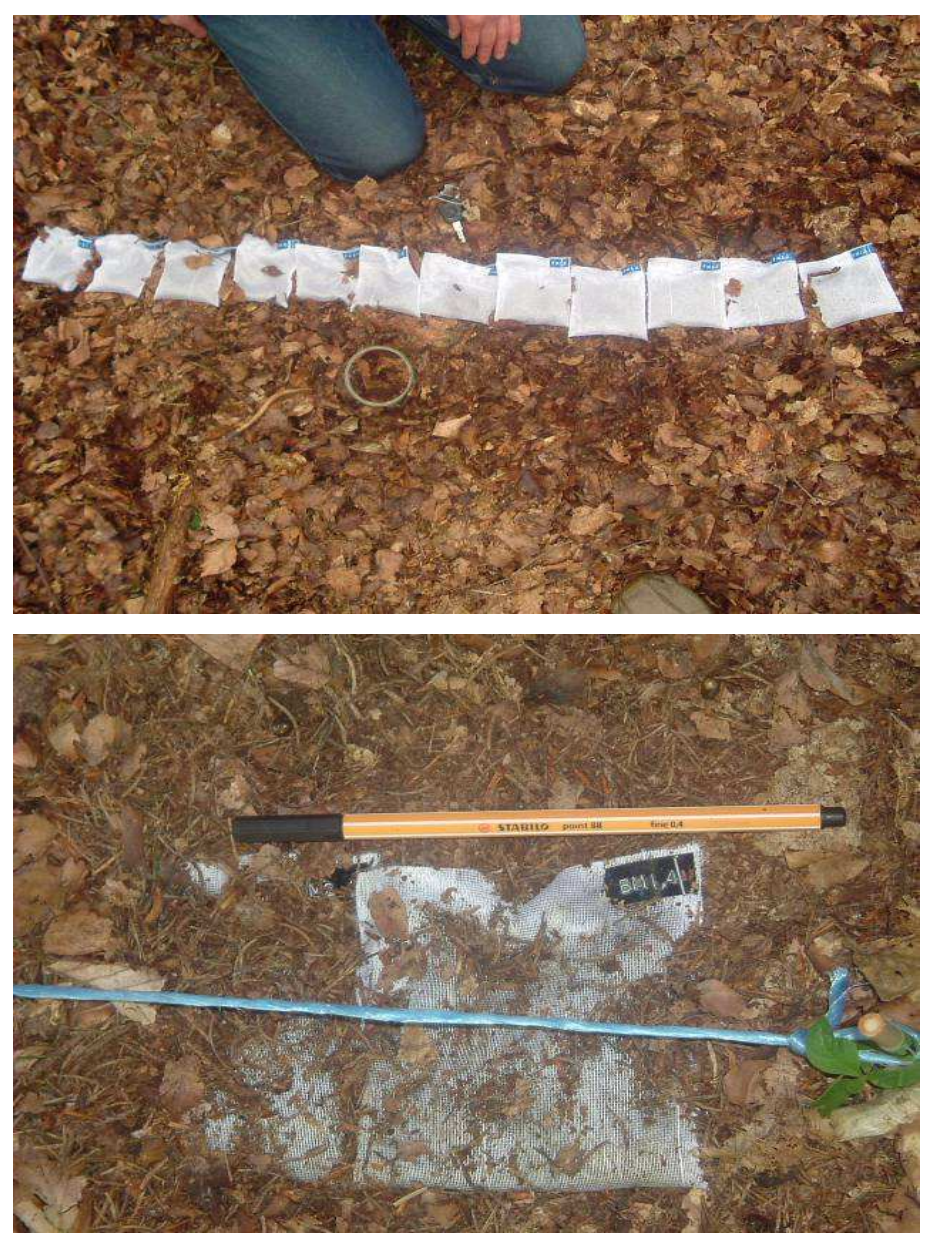

Fig.6. Placing of litterbags in the field.

\subsubsection{Soil respiration}

Since May 2005, four cylindrical PVC columns, $15 \mathrm{~cm}$ diameter and $25 \mathrm{~cm}$ tall were inserted approximately $10 \mathrm{~cm}$ into the organic and mineral soil under each canopy class in both plots. $\mathrm{CO}_{2}$ concentration was measured monthly from June 2005 (one month after installing the collars) to July 2006. Measurements were carried out twice per date between 10:00 and 15:00 by placing a PVC lid over each column and using a measuring device named CO2PORT (Messwert company GmbH-Göttingen) which was a developed version of an infrared gasanalysator (Edinburgh Sensors- Gascard II). The first measurement was done immediately after the closing the column and the second one after ca. 60 minuets. Before measuring, all green herbaceous vegetation was removed from the surface area enclosed by experimental cylinders. In winter season (Dec, Jan and Feb), because of heavy snow and ice layer on the measuring points, the soil $\mathrm{CO}_{2}$ emission could not be measured.

The temperatures were measured at $10 \mathrm{~cm}$ depth within soil and $5 \mathrm{~cm}$ above forest floor close to each PVC column at the time of $\mathrm{CO}_{2}$ measurement. In order to know the changes in 
temperature of forest floor, a digital thermometer (Cornad Electronic) were installed within $\mathrm{O}_{\mathrm{L}+\mathrm{F}}$ layer under each canopy class in both plots. A Barometer (Digital Barometer-Greisinger Electronic) was used to measure air pressure close to the chambers.

\subsection{Calculation and statistical analysis}

\section{Fluxes of element inputs}

To estimate the monthly flux of element inputs, the concentration of elements in throughfall $(\mathrm{mg} / \mathrm{L})$ or litterfall $(\mathrm{mg} / \mathrm{g})$ on each sampling occasion were multiplied by the amount of water, or mass of leaves and needles litterfall separately for each sampling occasion and month. Annual fluxes in all cases were the sum of 12-month estimated fluxes.

\section{Canopy leaching}

To calculate the rates of canopy leaching of cations $\left(\mathrm{K}^{+}, \mathrm{Ca}^{2+}, \mathrm{Mg}^{2+}\right)$ for each canopy class, I used the calculation approach developed by Ulrich (Ulrich, 1983; Bredemeier et al., 1988; Ulrich, 1994). The model assumes that foliar leaching of $\mathrm{Na}^{+}$is small and the ratio of throughfall and bulk precipitation of sodium can be used for determination of base cation leaching from the canopy.

Data on the annual amount of bulk precipitation and major element fluxes were available from the long-term monitoring plot $F 1$ at Solling which is located about $2 \mathrm{~km}$ from our plots (Meesenburg 2006, personal communication). According to these data the bulk precipitation at the site is characterised by higher fluxes of most of the elements (but not for $\mathrm{K}^{+}$and $\mathrm{Mn}^{2+}$ ) during the leafless period compared with the rest of the year (Tab.4).

Tab.4: Mean annual water and element fluxes $( \pm \mathrm{SD})$ of bulk precipitation $(\mathrm{n}=3)$ from $\mathrm{F} 1$ plot in Solling according to Meesenburg (2006, personal communication).

\begin{tabular}{lcccccccccccc}
\hline & $\begin{array}{c}\text { Water } \\
(\mathrm{mm})\end{array}$ & $\mathbf{p H}$ & $\mathbf{N a}^{+}$ & $\mathbf{K}^{+}$ & $\begin{array}{c}\mathbf{C a}^{2+} \\
\left(\mathrm{g} / \mathrm{m}^{2}\right)\end{array}$ & $\mathbf{M g}^{2+}$ & $\mathbf{M n}^{2+}$ & $\mathbf{N H}_{4}{ }^{+}$ & $\mathbf{N O}_{3}{ }^{-}$ & $\mathbf{S O}_{4}{ }^{2-}$ & $\mathbf{C l}^{-}$ \\
\hline Annual & $1112(6.8)$ & $5.04(0.02)$ & $0.65(0.01)$ & $0.12(0.01)$ & $0.17(0.0)$ & $0.06(0.0)$ & $0.0(0.0)$ & $0.73(0.0)$ & $0.60(0.01)$ & $0.56(0.0)$ & $1.01(0.03)$ \\
Summer & $496(3.1)$ & $5.02(0.01)$ & $0.20(0.01)$ & $0.07(0.01)$ & $0.07(0.0)$ & $0.02(0.0)$ & $0.0(0.0)$ & $0.27(0.0)$ & $0.22(0.0)$ & $0.23(0.01)$ & $0.22(0.01)$ \\
Winter & $616(3.8)$ & $5.05(0.02)$ & $0.45(0.0)$ & $0.05(0.0)$ & $0.10(0.0)$ & $0.04(0.0)$ & $0.0(0.0)$ & $0.46(0.0)$ & $0.38(0.0)$ & $0.37(0.0)$ & $0.79(0.02)$ \\
\hline
\end{tabular}




\section{Decomposition rate and $N$ turnover}

The decomposition rate of the litter was calculated using the standard decay function (Olsen, 1963):

$$
\mathrm{M}_{\mathrm{t}}=\mathrm{M}_{0} \mathrm{e}^{-k t}
$$

Where $\mathrm{M}_{\mathrm{t}}$ was the remaining mass at $\mathrm{t}, \mathrm{M}_{0}$ was the initial weight of the litter, $k$ was the decomposition constant and $t$ was the incubation time in the field in year.

Carbon and nitrogen content of decomposing needle litter was determined by the following equation:

$\%$ remaining carbon $($ or nitrogen $)=\left(\mathrm{M}_{\mathrm{t}} / \mathrm{M}_{0}\right) *\left(\mathrm{C}_{\mathrm{t}} / \mathrm{C}_{0}\right) * 100$

Where $\mathrm{M}_{\mathrm{t}}$ was the remaining mass at $\mathrm{t}, \mathrm{M}_{0}$ was the initial weight of the litter, $\mathrm{Ct}$ was the concentration of element in decomposing litter at the time of sampling, $\mathrm{C}_{0}$ was the initial concentration of element.

It was assumed that the biogeochemical differences (i. e. changes in $\mathrm{N}$ availability via throughfall) among subplots may influence the $\mathrm{N}$ dynamic. A simultaneously release of litter $\mathrm{N}$ and incorporating of external $\mathrm{N}$ to decomposing litter is a general finding of the investigations on litter decomposition (Staaf, 1988; Berg, 2000; Gebauer et al., 2000). Throughfall, micro-organisms and soil $\mathrm{N}$ are the possible external source of incorporating $\mathrm{N}$ to decomposing litter.

In order to assess the $\mathrm{N}$ dynamics in decomposing litter under different canopy classes, ${ }^{15} \mathrm{~N}$ labelled litter was used. The stable isotope is composed of one major abundance isotope and one or two isotopes of relatively minor abundance. The low abundance of these isotopes provides opportunities to use enriched sources of the isotopes as tracers in biochemical studies. The enrichment of the isotope is usually expressed as atom\% excess, which is the percent of atoms as the minor isotope in excess of their background abundance.

${ }^{15} \mathrm{~N}$ abundance $\left(\delta^{15} \mathrm{~N}\right)$ is expressed as per mill deviation from atmospheric standard of 0.3663 atom $\%{ }^{15} \mathrm{~N}$, or atom $\%{ }^{15} \mathrm{~N}$.

$$
\delta^{15} N=\left(\frac{R_{\text {sample }}}{R_{\text {stan dard }}}-1\right) * 1000
$$

where $R$ is the ratio of ${ }^{15} \mathrm{~N} /{ }^{14} \mathrm{~N} . \delta^{15} \mathrm{~N}$ excess was calculated from enriched ${ }^{15} \mathrm{~N}$ value subtracted by natural ${ }^{15} \mathrm{~N}$ abundance (Dawson and Brooks, 2001). 
$\delta^{15} \mathrm{~N}$ excess can be used as the indicator of changes in $\mathrm{N}$ concentrations within decomposing litter. Sine the release rate of ${ }^{15} \mathrm{~N}$ from labelled needle litter remain nearly constant and in coincide, external $\mathrm{N}$ was incorporated into the decomposing litter. Therefore, any change in ${ }^{15} \mathrm{~N} /{ }^{14} \mathrm{~N}$ ratio results from the change in ${ }^{14} \mathrm{~N}$ content. Hence, one can calculated the percentage of released / incorporated $\mathrm{N}$ to initial $\mathrm{N}$ by means of the differences in $\delta^{15} \mathrm{~N}$ excess in different stages of decomposing litter in litterbag experiment (Gebauer et al., 2000).

$\mathrm{CO}_{2}$ efflux

CO2 fluxes were calculated with the formula suggested by Borken (1996)

$\mathrm{F}_{\mathrm{CO} 2-\mathrm{C}}=(d c / d t) *\left(\left(M_{M} * V_{H}\right) /\left(M_{V} * A_{H}\right)\right) *\left(P_{a} / P_{N} *\left(1+0.00367 * T_{a}\right)\right)$

$\mathrm{F}_{\mathrm{CO} 2-\mathrm{C}}=\mathrm{CO}_{2}-\mathrm{C}$ flux $\left(\mathrm{mg} \mathrm{m}^{2} \mathrm{~h}^{-1}\right)$

$\mathrm{dc} / \mathrm{dt}=$ temporal change in $\mathrm{CO}_{2}$ concentration within chamber $\left(\mathrm{ppm} \min ^{-1}\right)$

$\mathrm{M}_{\mathrm{M}} \quad=$ Mass of $\mathrm{CO}_{2}-\mathrm{C}$ mole $\left(12.01 \mathrm{~g} \mathrm{~mol}^{-1}\right)$

$\mathrm{V}_{\mathrm{H}} \quad=$ Volume of chamber $(\mathrm{L})$

$\mathrm{M}_{\mathrm{V}} \quad=$ Volume of $\mathrm{CO}_{2}\left(22.26 \mathrm{~L} \mathrm{~mol}^{-1}\right)$

$\mathrm{A}_{\mathrm{H}} \quad=$ Basal area of chamber $\left(\mathrm{m}^{2}\right)$

$\mathrm{P}_{\mathrm{N}} \quad=$ Normal air pressure $(1013 \mathrm{hPa})$

$\mathrm{P}_{\mathrm{a}} \quad=$ Actual air pressure $(\mathrm{hPa})$

$\mathrm{T}_{\mathrm{a}} \quad=$ Actual air temperature $\left({ }^{\circ} \mathrm{C}\right)$

Total Belowground Carbon Allocation (TBCA)

A conceptual model (developed by Raich and Nadelhoffer, 1989) was used to quantify the fluxes of carbon.

Soil respiration is the $\mathrm{CO}_{2}$ flux from the soil and is comprised of root respiration, microbial decomposition of soil organic matter derived from dead roots, root exudates, and mycorrhizal hyphae, and microbial decomposition of aboveground litterfall:

Soil respiration $=$ Root respiration + Root litter $C$ decomposition + Aboveground litter $C$ decomposition 
Raich and Nadelhoffer (1989) suggested that total belowground carbon allocation (TBCA) could be estimate from the difference between annual rates of soil respiration and aboveground litterfall.

Soil respiration $=T B C A+$ Aboveground Litterfall- $C$

The model assumes that the stocks of organic matter, root and litter in soil are in steady state and the amount of annual litterfall equals the amount of decomposition of aboveground litter.

Aboveground litter $C$ decomposition $=$ Aboveground litterfall- $C$

Therefore, TBCA equal to root respiration and root litter $\mathrm{C}$ decomposition, which is expressed in equation (4):

$T B C A=$ Root respiration + Root litter $C$ decomposition

In this model, annual changes in the soil and litter stores must be small relative to soil respiration and litterfall C. In current study, I used the mean annual carbon flux via foliar litterfall as the litterfall C.

\section{Statistical analyses}

Differences in mean element concentrations and fluxes in water and foliar litterfall between plots were tested by the Student's $t$ test at the $95 \%$ confidence level. The other data were analysed using one-way analysis of variance (ANOVA) after checking the assumptions for parametric test. The non-parametric data were transformed to achieve normal distribution and homogeneous variances. The Tukey HSD test was used to determine significant differences at the level of $p<0.05$. STATISTICA 7.0 was applied for statistical analyses. 


\section{Results}

\subsection{Nutrient inputs}

\subsubsection{Throughfall}

Throughfall amounts were significantly higher in the leafless period (November to April) in all canopy classes compared to the leafed period (May to October, data not shown) in beech (BDP and spruce (SDP) dominated plots. The annual throughfall water fluxes in different canopy classes in both plots followed the same pattern and tended to decrease in the order gap > mixed $>$ beech > spruce but showed significant differences only between gap and spruce. In the SDP, in addition, the annual water flux under spruce differed significantly from the water fluxes under the beech and mixed canopies (Tab. 5). The amounts of annual throughfall water in all canopy classes were higher in the BDP than corresponding canopy classes in the SDP, the differences being highest under the spruce canopies $(+34 \%)$ and lowest under the beech canopies $(+10 \%)$.

The annual $\mathrm{pH}$ values of throughfall under beech canopy classes in both plots tended to be higher than under other canopy categories, but the differences were not significant due to wide variations (Tab. 5). The $\mathrm{pH}$ values were higher under spruce and mixed canopies in the BDP compared with the same canopy categories in the SDP (Tab.5). The seasonal variability of $\mathrm{pH}$ was observed in both plots. The $\mathrm{pH}$ values of throughfall in the leafless period were lower but they were higher (more than 1 unit) in the leafed period compared to the $\mathrm{pH}$ of bulk precipitation, especially in the SDP (Fig.7). 
Tab.5: Mean $( \pm$ SD) annual water and element fluxes via throughfall in the beech (BDP) and spruce (SDP) dominated plot $\left(\mathrm{g} / \mathrm{m}^{-2}\right.$ year $)$.

\begin{tabular}{|c|c|c|c|c|c|c|c|c|}
\hline \multicolumn{2}{|c|}{$B D P$} & \multicolumn{6}{|c|}{$S D P$} & \multirow{3}{*}{$\begin{array}{l}\text { GAP } \\
\mathrm{n}=3\end{array}$} \\
\hline & SPRUCE & MIXED & ВEECH & GAP & SPRUCE & MIXED & ВEECH & \\
\hline & $\mathrm{n}=3$ & $\mathrm{n}=3$ & $\mathrm{n}=3$ & $\mathrm{n}=3$ & $\mathrm{n}=3$ & $\mathrm{n}=3$ & $\mathrm{n}=3$ & \\
\hline \multirow[t]{2}{*}{ Water* } & $\begin{array}{l}578.6 \\
\end{array}$ & 667.0 & 616.3 & 703.2 & 432.3 & 566.3 & 562.1 & 611.4 \\
\hline & (81.7) a $\mathbf{B}$ & (27.7) ab B & (19.6) ab B & (27.0) b B & (23.3) a $\mathbf{A}$ & (32.0) b A & (24.0) b A & (11.6) b A \\
\hline \multirow[t]{2}{*}{ pH } & 5.7 & 5.8 & 6.1 & 5.7 & 5.4 & 5.5 & 5.8 & 5.6 \\
\hline & $(0.10) \mathbf{B}$ & $(0.05) \mathbf{B}$ & $(0.20)$ & $(0.06)$ & $(0.05) \mathbf{A}$ & $(0.15) \mathbf{A}$ & $(0.30)$ & $(0.05)$ \\
\hline \multirow[t]{2}{*}{$\mathrm{Na}^{+}$} & 2.07 & 1.60 & 0.89 & 0.93 & 1.78 & 1.73 & 0.80 & 1.05 \\
\hline & $(0.03) \mathrm{c}$ & $(0.10) \mathrm{b}$ & $(0.19)$ a & $(0.06) \mathrm{a}$ & $(0.23) \mathrm{b}$ & $(0.17) b$ & $(0.07) \mathrm{a}$ & $(0.09)$ a \\
\hline \multirow[t]{2}{*}{$\mathbf{K}^{+}$} & 2.63 & 3.03 & 2.04 & 1.11 & 2.42 & 3.22 & 1.42 & 1.41 \\
\hline & $(0.41) b c$ & $(0.07) \mathrm{c}$ & $(0.34)$ b B & $(0.33) \mathrm{a}$ & $(0.22) \mathrm{b}$ & $(0.31) \mathrm{c}$ & $(0.06)$ a $\mathbf{A}$ & $(0.10) \mathrm{a}$ \\
\hline \multirow[t]{2}{*}{$\mathrm{Ca}^{2+}$} & 1.18 & 0.95 & 0.62 & 0.43 & 1.43 & 1.43 & 0.59 & 0.80 \\
\hline & $(0.13)$ c $\mathbf{A}$ & $(0.03) \mathrm{b} \mathbf{A}$ & $(0.08)$ a & $(0.04)$ a $\mathbf{A}$ & $(0.04)$ b B & $(0.23) \mathrm{b} \mathbf{B}$ & $(0.04) \mathrm{a}$ & $(0.16)$ a $\mathbf{B}$ \\
\hline \multirow[t]{2}{*}{$\mathbf{M g}^{2+}$} & 0.45 & 0.38 & 0.28 & 0.21 & 0.47 & 0.52 & 0.20 & 0.27 \\
\hline & $(0.03) \mathrm{d}$ & $(0.02) \mathrm{c}$ & $(0.03) \mathrm{b} \mathbf{B}$ & $(0.02) \mathrm{a}$ & $(0.03) \mathrm{b}$ & $(0.11) b$ & $(0.02)$ a $\mathbf{A}$ & $(0.03) \mathrm{a}$ \\
\hline \multirow[t]{2}{*}{$\mathbf{M n}^{2+}$} & 0.33 & 0.27 & 0.25 & 0.14 & 0.44 & 0.52 & 0.12 & 0.19 \\
\hline & $(0.03) \mathrm{c} \mathbf{A}$ & $(0.02) b c$ & $(0.02) \mathrm{b} \mathbf{B}$ & $(0.02) \mathrm{a}$ & $(0.02)$ b B & $(0.15) \mathrm{b}$ & $(0.01)$ a $\mathbf{A}$ & $(0.03) \mathrm{a}$ \\
\hline \multirow[t]{2}{*}{$\mathrm{NH}^{+}$} & 1.52 & 1.17 & 0.77 & 0.71 & 1.59 & 1.42 & 0.83 & 0.99 \\
\hline & $(0.16) \mathrm{c}$ & $(0.15) \mathrm{b}$ & $(0.06) \mathrm{a}$ & $(0.06)$ a $\mathbf{A}$ & $(0.14) b$ & $(0.08) \mathrm{b}$ & $(0.20) \mathrm{a}$ & $(0.05)$ a $\mathbf{B}$ \\
\hline \multirow[t]{2}{*}{$\mathrm{NO3}^{-}$} & 1.76 & 1.22 & 0.61 & 0.65 & 1.40 & 1.61 & 0.68 & 0.88 \\
\hline & $(0.14)$ c B & $(0.12) \mathrm{b} \mathrm{A}$ & $(0.08) \mathrm{a}$ & $(0.02)$ a $\mathbf{A}$ & $(0.03) \mathrm{b} \mathbf{A}$ & $(0.25)$ b B & $(0.20) \mathrm{a}$ & $(0.03)$ a $\mathbf{B}$ \\
\hline \multirow[t]{2}{*}{$\mathrm{SO}^{2-}$} & 1.59 & 1.25 & 0.80 & 0.69 & 1.89 & 1.97 & 0.81 & 1,05 \\
\hline & $(0.21) \mathrm{c} \mathbf{A}$ & $(0.03) \mathrm{b} \mathrm{A}$ & $(0.09)$ a & $(0.04)$ a $\mathbf{A}$ & $(0.03) \mathrm{b} \mathbf{B}$ & $(0.27)$ b B & $(0.05) \mathrm{a}$ & $(0.08)$ a $\mathbf{B}$ \\
\hline \multirow[t]{2}{*}{$\mathrm{Cl}^{-}$} & 4.32 & 3.20 & 1.92 & 1.84 & 3.83 & 3.99 & 1.84 & 2.33 \\
\hline & $(0.34) \mathrm{c}$ & $(0.21) \mathrm{b}$ & $(0.36) \mathrm{a}$ & $(0.20)$ a $\mathbf{A}$ & $(0.19) \mathrm{b}$ & $(0.49) \mathrm{b}$ & $(0.15) \mathrm{a}$ & $(0.16)$ a $\mathbf{B}$ \\
\hline \multirow[t]{2}{*}{ DOC } & 10.5 & 7.84 & 5.67 & 3.61 & 13.1 & 11.8 & 6.10 & 7.46 \\
\hline & $(0.84) \mathrm{d} \mathbf{A}$ & $(0.31)$ c $\mathbf{A}$ & $(0.64) \mathrm{b}$ & $(0.81)$ a $\mathbf{A}$ & $(0.86)$ b B & $(0.76)$ b B & $(0.29)$ a & $(0.61)$ a $\mathbf{B}$ \\
\hline \multirow[t]{2}{*}{$\mathbf{N}_{\text {org }}$} & 0.44 & 0.33 & 0.23 & 0.16 & 0.45 & 0.39 & 0.27 & 0.25 \\
\hline & $(0.05) \mathrm{c}$ & $(0.04) \mathrm{b}$ & $(0.03) \mathrm{a}$ & $(0.02)$ a $\mathbf{A}$ & $(0.04) \mathrm{c}$ & $(0.09) \mathrm{bc}$ & $(0.12) \mathrm{ab}$ & $(0.03)$ a $\mathbf{B}$ \\
\hline
\end{tabular}

$*=\mathrm{mm}=\mathrm{L} / \mathrm{m}^{2}$

Values in brackets indicate the standard deviation $( \pm \mathrm{SD})$.

Different letters indicate significant $(\mathrm{p}<0.05)$ differences under different canopy classes. Lower-case letters represent differences within plots and upper-case letters represent differences between plots. No letter means no significant difference

In the SDP, the annual fluxes of all elements with the exception of $\mathrm{K}^{+}, \mathrm{N}_{\text {org }}$, DOC followed the order: spruce $=$ mixed $>$ beech $=$ gap. In the BDP, for most of the elements $\left(\mathrm{Ca}^{2+}\right.$, all forms of nitrogen, $\mathrm{SO}_{4}{ }^{2-}, \mathrm{Na}^{+}, \mathrm{Cl}^{-}$) the differences between spruce and other canopy categories were more pronounced, resulting in the following pattern: spruce $>$ mixed $>$ beech=gap. For $\mathrm{Mg}^{2+}$ and DOC in this plot there were, in addition, significant differences between beech and gap. $\mathrm{Mn}^{2+}$ followed the same pattern as most of the elements but the mixed canopy did not show any differences in $\mathrm{Mn}^{2+}$ flux compared with the spruce and beech canopy classes. The fluxes of $\mathrm{K}^{+}$in both plots were highest under the mixed canopy, although in the BDP the fluxes of potassium under spruce and mixed canopy did not differ at the 0.05 significant levels. In the 
$\mathrm{BDP}$, the $\mathrm{K}^{+}$fluxes in the gap were significantly lower than under other canopy classes, while in the SDP the corresponding flux in the gap and under beech canopy were the same.
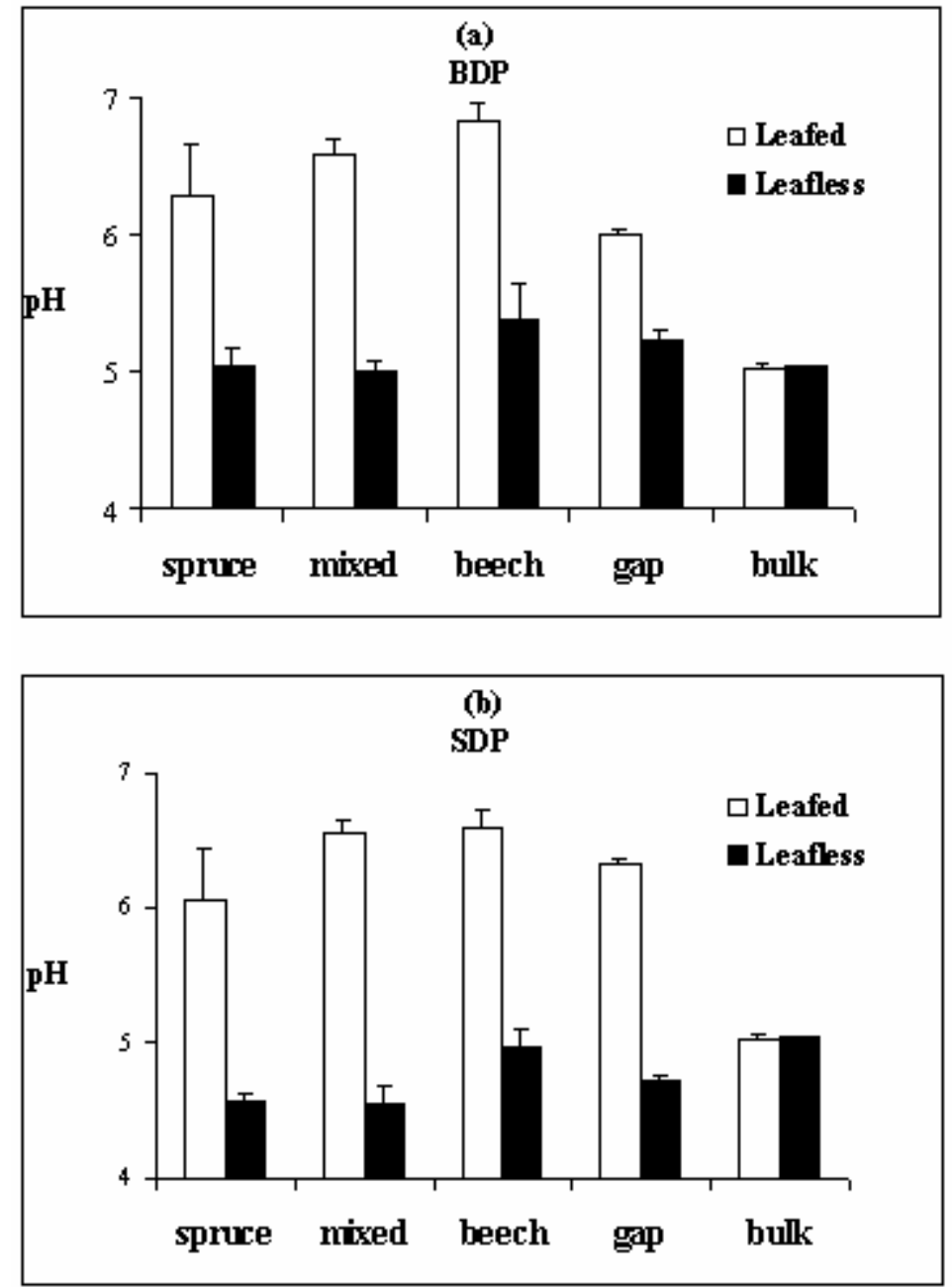

Fig.7: Mean $\mathrm{pH}$ values $( \pm \mathrm{SD})$ of throughfall in leafed and leafless periods under different canopy classes in a) beech (BDP) and b) spruce (SDP) dominated plots and in bulk precipitation.

The canopy leaching calculation of base cations based on the Ulrich model (1983) showed that $\mathrm{K}^{+}$leaching in both plots was highest under mixed canopy classes. The leached amounts of base cations $\left(\mathrm{K}^{+}, \mathrm{Ca}^{2+}, \mathrm{Mg}^{2+}\right)$ were significantly higher under the spruce than under the beech canopy in both plots. In the BDP, the gap class exhibited by far the lowest amounts of cation leaching (Fig. 8a). But in the SDP, no significant differences was found in leached amounts of $\mathrm{K}^{+}$and $\mathrm{Mg}^{2+}$ between gap and beech, and the canopy leaching of $\mathrm{Ca}^{2+}$ in the gap was also significantly greater than under beech (Fig. 8b). 

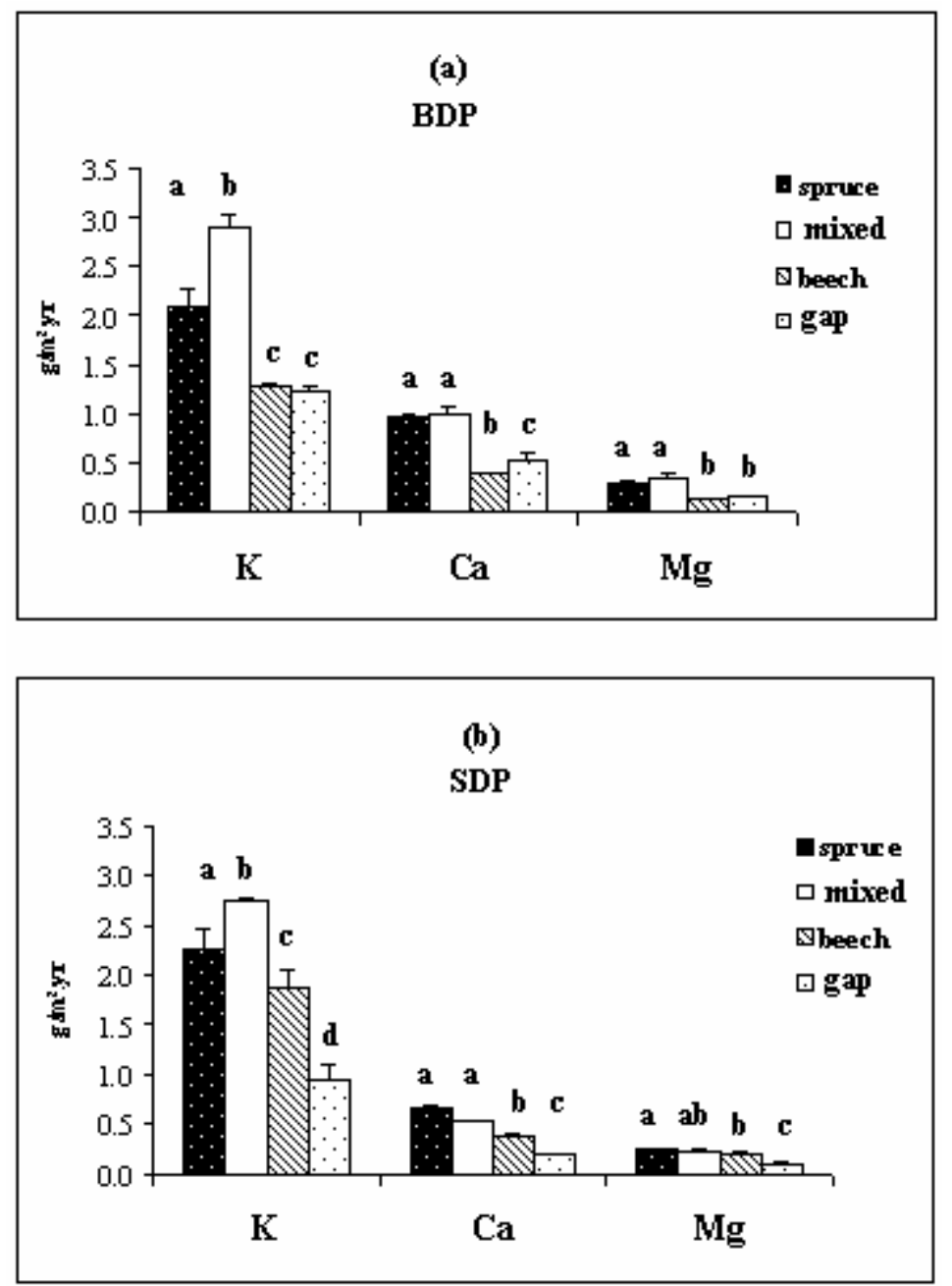

Fig.8: Mean $( \pm \mathrm{SD})$ annual canopy leaching of base cations under different canopy classes in a) beech (BDP) and b) spruce (SDP) dominated plots. Different letters indicate significant $(\mathrm{p}<0.05)$ differences between canopy classes. 


\subsubsection{Litterfall}

The amounts of total litterfall under different canopy classes in the BDP tended to decrease in the order beech $>$ mixed $>$ spruce $>$ gap and in the order spruce $>$ gap $>$ beech $>$ mixed in the SDP, but the differences were not significant. The flux of total litterfall under mixed and beech canopies was significantly greater in the BDP than in the SDP but not for the other canopy classes (Tab. 6)

Tab.6: Mean $( \pm \mathrm{SD})$ annual dry mass of different litterfall compartments under different canopy classes in the beech (BDP) and spruce (SDP) dominated plot ( $\mathrm{g} / \mathrm{m}^{-2}$ year $\left.{ }^{-}\right)$.

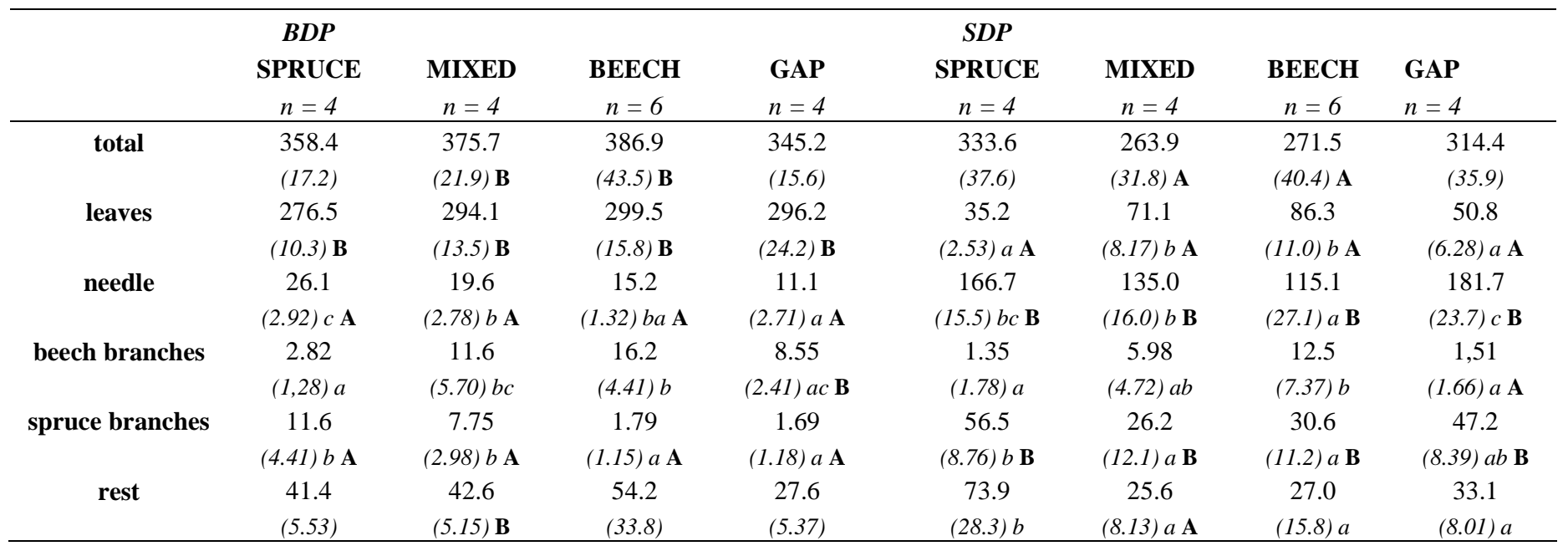

Values in brackets indicate the standard deviation $( \pm \mathrm{SD})$.

Different letters indicate significant $(\mathrm{p}<0.05)$ differences under different canopy classes. Lower-case letters represent differences within plots and upper-case letters represent differences between plots. No letter means no significant difference

The foliar litter as the main fraction of litterfall represented $80-90 \%$ and $60-80 \%$ of total litterfall in the BDP and SDP, respectively. No significant differences were found in beech leaf litter production under different canopy classes in the BDP, but in the SDP the significantly highest amounts of beech leaf litterfall were recorded under the beech and mixed canopy classes. The leaf litterfall under the four canopy classes showed significantly higher annual amounts in the BDP compared with the SDP.

The fluxes of needle litter under different canopy classes in the BDP tended to decrease in the order: spruce $>$ mixed $\geq$ beech $\geq$ gap with a significantly greater amount under spruce compared to other canopy classes (Tab. 6). In the SDP, the higher amounts of needle litter were found in gaps and under the spruce canopies, resulting in the following order: gap $\geq$ spruce $\geq$ mixed > beech (Tab. 6). The production of needle litter under all canopy classes in the BDP was significantly lower than the corresponding canopy classes in the SDP. 
The temporal distribution of leaf litter fall showed the maximum beech leaf litterfall in both plots in October. In contrast to leaf litter, needle litterfall peaked at two different times in November and in May which was mostly pronounced in the spruce dominated plot (Fig. 9).
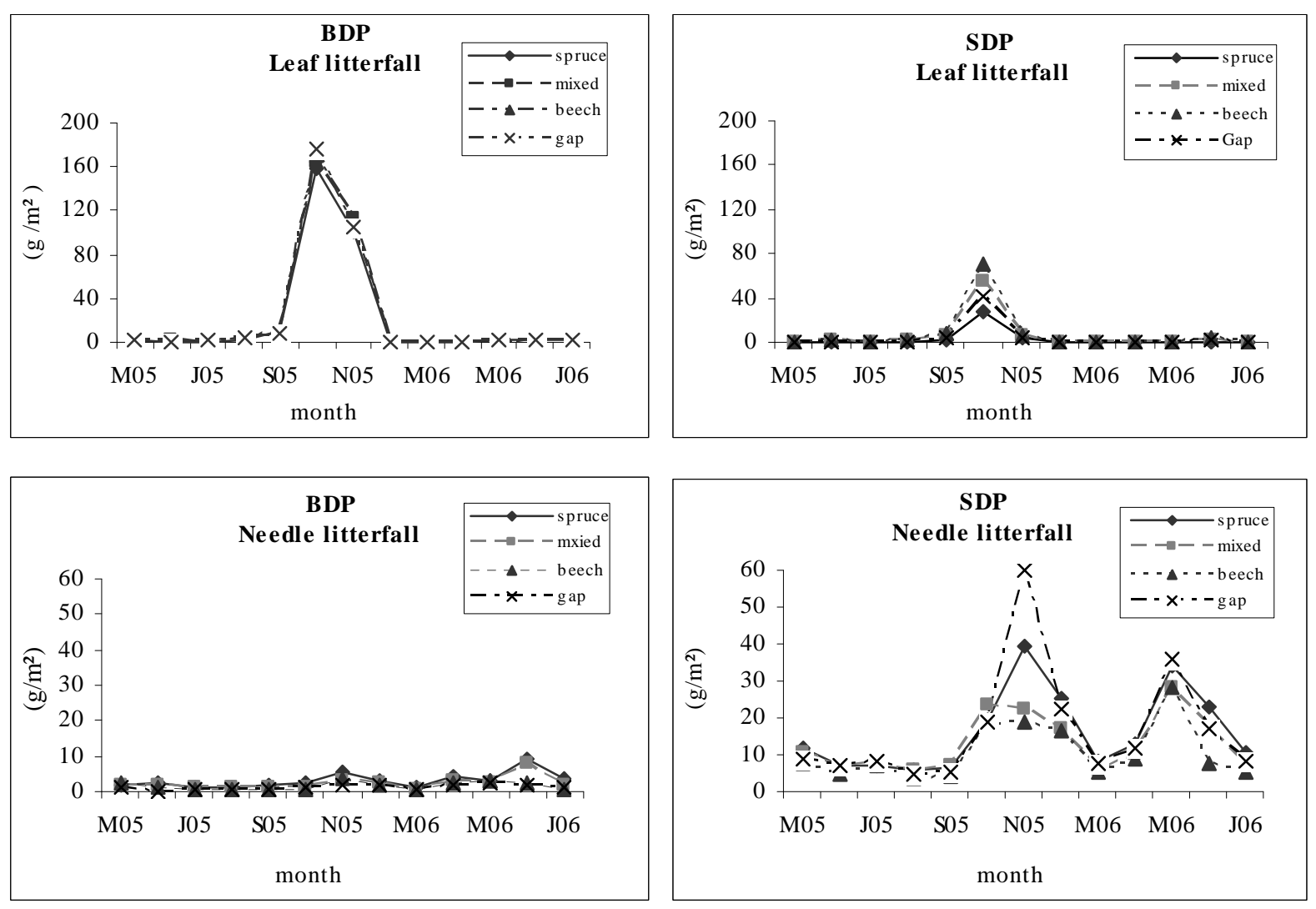

Fig. 9: Monthly leaf and needle litter distribution under different canopy classes in the beech (BDP) and spruce (SDP) dominated plots.

Regardless of the canopy classes, the mean concentrations of potassium, calcium and manganese in leaf and needle litter (Fig.10) produced in the BDP were significantly higher than in the litter produced in the SDP. The concentrations of $\mathrm{N}$ in beech foliar litter were higher in the SDP than in the BDP, while spruce foliar litter showed no differences between the plots $(\mathrm{p}<0.05)$. The concentration of all other elements exhibited no significantly differences in both leaf and needle litter fractions between the two plots. 

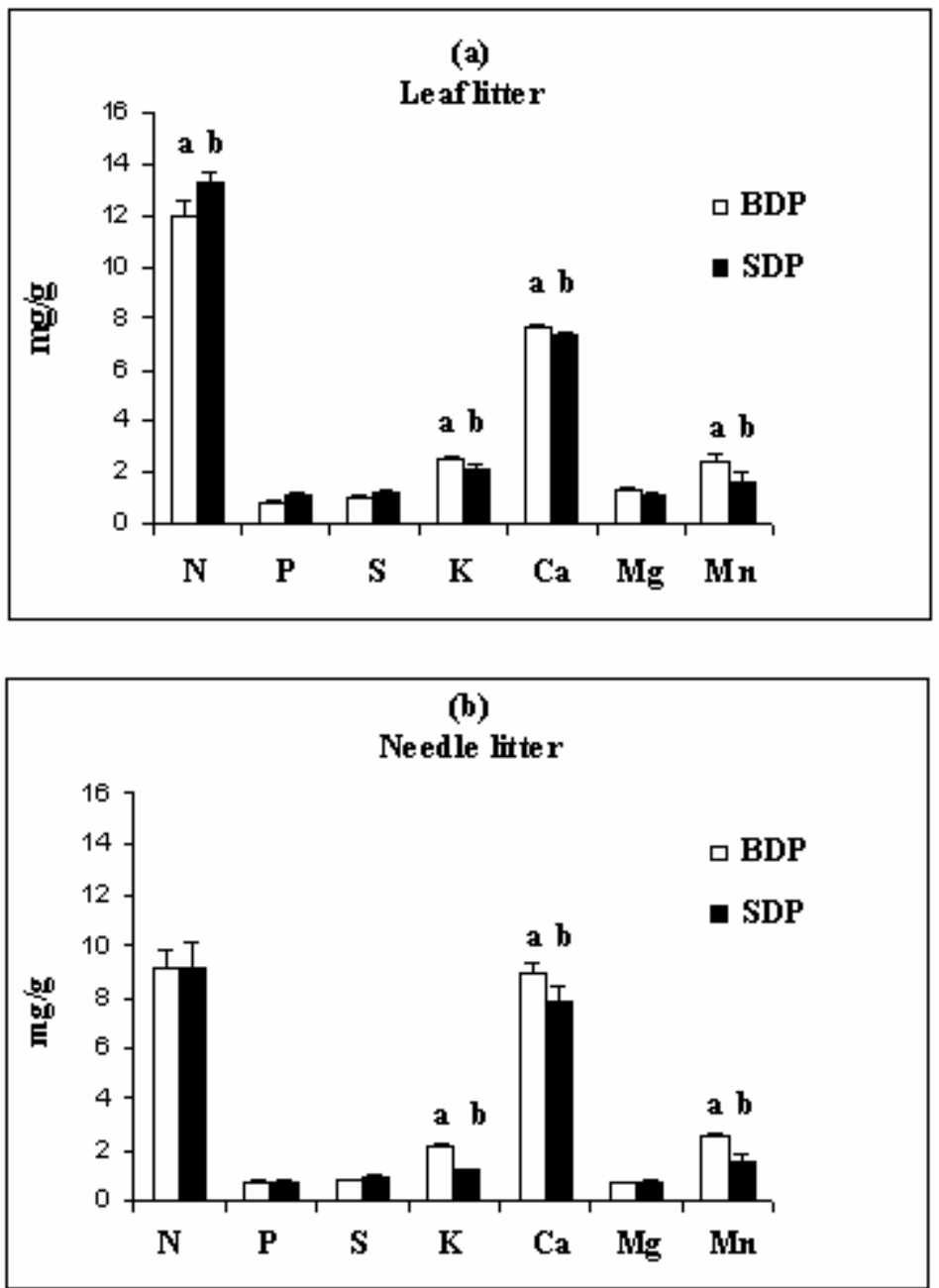

Fig. 10: Mean $( \pm S D)$ element concentration in leaf (a) and needle (b) litter in the beech (BDP) and spruce (SDP) dominated plots. Different letters indicate significant $(\mathrm{p}<0.05)$ differences between plots.

A comparison of annual element fluxes via foliage litterfall among different canopy classes in the BDP did not indicate any significant differences $(\mathrm{p}<0.05)$ for any of the considered elements (Tab. 7).

In the SDP, the annual return of $\mathrm{Mg}$ to the forest floor via foliar litterfall was lower under spruce canopy than under beech and mixed canopies, while other elements showed no significant differences under different types of canopies (Tab. 7). The amount of total foliar litterfall was higher in the BDP than in the SDP (Tab. 7) and considerably higher annual fluxes of elements via litterfall under all canopy classes were recorded in the BDP compared to the corresponding values in the SDP. 
Tab.7: Mean $( \pm$ SD) annual mass and element fluxes via foliar litterfall under different canopy classes in the beech (BDP) and spruce (SDP) dominated plots ( $\mathrm{g} / \mathrm{m}^{-2}$ year $)$.

\begin{tabular}{|c|c|c|c|c|c|c|c|c|}
\hline & \multirow{2}{*}{$\begin{array}{c}\text { BDP } \\
\text { SPRUCE } \\
n=4\end{array}$} & \multicolumn{7}{|c|}{$S D P$} \\
\hline & & $\begin{array}{c}\text { MIXED } \\
n=4\end{array}$ & $\begin{array}{c}\text { BEECH } \\
n=6\end{array}$ & $\begin{array}{l}\text { GAP } \\
n=4\end{array}$ & $\begin{array}{c}\text { SPRUCE } \\
n=4\end{array}$ & $\begin{array}{c}\text { MIXED } \\
n=4\end{array}$ & $\begin{array}{c}\text { BEECH } \\
n=6\end{array}$ & $\begin{array}{l}\text { GAP } \\
n=4\end{array}$ \\
\hline \multirow[t]{2}{*}{ mass } & 302.6 & 313.7 & 314.7 & 307.3 & 201.9 & 206.1 & 201.4 & 232.5 \\
\hline & (12.3) & (14.4) & (15.4) & $(22.3)$ & $(17.0)$ & (18.7) & (25.9) & $(28.1)$ \\
\hline \multirow[t]{2}{*}{$\mathbf{N a}$} & 0.05 & 0.05 & 0.05 & 0.04 & 0.02 & 0.03 & 0.02 & 0.03 \\
\hline & $(0.00)$ & $(0.00)$ & $(0.01)$ & $(0.00)$ & $(0.00)$ & $(0.01)$ & $(0.00)$ & $(0.00)$ \\
\hline \multirow[t]{2}{*}{$\mathbf{K}$} & 0.74 & 0.77 & 0.82 & 0.75 & 0.27 & 0.29 & 0.30 & 0.32 \\
\hline & $(0.05)$ & $(0.06)$ & $(0.08)$ & $(0.04)$ & $(0.04)$ & $(0.07)$ & $(0.05)$ & $(0.06)$ \\
\hline \multirow[t]{2}{*}{ Ca } & 2.43 & 2.54 & 2.51 & 2.43 & 1.58 & 1.67 & 1.56 & 1.77 \\
\hline & $(0.13)$ & $(0.14)$ & $(0.18)$ & $(0.22)$ & $(0.36)$ & $(0.18)$ & $(0.14)$ & $(0.36)$ \\
\hline \multirow[t]{2}{*}{ Mg } & 0.36 & 0.40 & 0.40 & 0.39 & 0.14 & 0.19 & 0.19 & 0.17 \\
\hline & $(0.02)$ & $(0.02)$ & $(0.02)$ & $(0.04)$ & $(0.01) a$ & $(0.02) b$ & $(0.03) b$ & $(0.02) a b$ \\
\hline \multirow[t]{2}{*}{ Mn } & 0.76 & 0.80 & 0.82 & 0.79 & 0.33 & 0.30 & 0.28 & 0.38 \\
\hline & $(0.03)$ & $(0.04)$ & $(0.06)$ & $(0.07)$ & $(0.08)$ & $(0.06)$ & $(0.02)$ & $(0.11)$ \\
\hline \multirow[t]{2}{*}{$\mathbf{S}$} & 0.28 & 0.28 & 0.29 & 0.28 & 0.19 & 0.20 & 0.20 & 0.21 \\
\hline & $(0.01)$ & $(0.02)$ & $(0.02)$ & $(0.02)$ & $(0.02)$ & $(0.02)$ & $(0.03)$ & $(0.02)$ \\
\hline \multirow[t]{2}{*}{$\mathbf{N}$} & 2.95 & 2.99 & 3.06 & 2.99 & 1.93 & 2.10 & 2.10 & 2.16 \\
\hline & $(0.10)$ & $(0.21)$ & $(0.08)$ & $(0.25)$ & $(0.14)$ & $(0.13)$ & $(0.32)$ & $(0.17)$ \\
\hline \multirow[t]{2}{*}{ C } & 156.6 & 162.3 & 163.8 & 160.1 & 105.7 & 105.1 & 103.3 & 119.2 \\
\hline & $(6.39)$ & (7.0) & $(8.1)$ & (11.5) & $(10.2)$ & $(9.09)$ & $(13.1)$ & (14.2) \\
\hline
\end{tabular}

Values in brackets indicate the standard deviation $( \pm \mathrm{SD})$.

Different letters indicate significant $(\mathrm{p}<0.05)$ differences under different canopy classes. No letter means no significant difference

\subsubsection{Total element inputs:}

The contribution of litterfall and throughfall to transport elements from the canopy to soil differed for different elements. In both plots, throughfall was the main pathway for sodium, potassium and sulphur but for calcium the major pathway was litterfall. For nitrogen and magnesium litterfall and throughfall showed a relatively similar contribution to the total nutrient inputs. For most elements, the contribution of throughfall in all canopy classes was greater in the SDP than in the BDP. The total inputs of all elements, with the exception of sulphur for all canopy categories and for Na in gaps, were higher in the BDP than in the SDP.

Spruce and mixed canopy classes showed the highest total inputs for all studied elements in both plots. The total inputs of $\mathrm{K}$ in mixed canopy classes were considerably higher than under spruce canopy and under the other canopy categories (Tab. 8). 
Tab. 8: Total annual input of elements via throughfall (TF) and litterfall (LF) under different canopy classes in the beech (BDP) and spruce (SDP) dominated plots.

\begin{tabular}{|c|c|c|c|c|c|c|c|c|c|c|c|c|}
\hline & $\begin{array}{c}\text { Spruce } \\
\left(\mathrm{g} / \mathrm{m}^{-2} \text { year }\right) \\
\end{array}$ & $T F$ & $L F$ & $\begin{array}{c}\text { Mixed } \\
\left(\mathrm{g} / \mathrm{m}^{-2} \text { year }\right)\end{array}$ & $T F$ & $L F$ & $\begin{array}{c}\text { Beech } \\
\left(\mathrm{g} / \mathrm{m}^{-2} \text { year }\right)\end{array}$ & $T F$ & $L F$ & $\begin{array}{c}\text { Gap } \\
\left(\mathrm{g} / \mathrm{m}^{-2}\right. \\
\text { year }) \\
\end{array}$ & $T F$ & $L F$ \\
\hline \multicolumn{13}{|c|}{$B D P$} \\
\hline $\mathrm{Na}$ & 2.1 & 98 & 2 & 1.7 & 97 & 3 & 0.95 & 95 & 5 & 0.97 & 96 & 4 \\
\hline$K$ & 3.4 & 78 & 22 & 3.8 & 80 & 20 & 2.9 & 72 & 28 & 1.9 & 60 & 40 \\
\hline $\mathrm{Ca}$ & 3.6 & 33 & 67 & 3.5 & 27 & 73 & 3.1 & 20 & 80 & 2.9 & 15 & 85 \\
\hline$M g$ & 0.81 & 56 & 44 & 0.78 & 49 & 51 & 0.68 & 62 & 38 & 0.60 & 35 & 65 \\
\hline$S$ & 1.9 & 82 & 18 & 1.5 & 82 & 18 & 1.1 & 74 & 26 & 0.97 & 71 & 29 \\
\hline$N$ & 6.7 & 56 & 44 & 5,7 & 48 & 52 & 4.7 & 35 & 65 & 4.5 & 34 & 66 \\
\hline$C$ & 167 & 6 & 94 & 170 & 5 & 95 & 170 & 3 & 97 & 164 & 2 & 98 \\
\hline \multicolumn{13}{|c|}{$S D P$} \\
\hline$N a$ & 1.8 & 99 & 1 & 1.8 & 98 & 2 & 0.83 & 96 & 4 & 1.1 & 97 & 3 \\
\hline$K$ & 2.7 & 90 & 10 & 3.5 & 92 & 8 & 1.7 & 85 & 15 & 1.7 & 82 & 18 \\
\hline $\mathrm{Ca}$ & 3.0 & 48 & 52 & 3.1 & 46 & 54 & 2.2 & 28 & 72 & 2.6 & 31 & 69 \\
\hline$M g$ & 0.61 & 77 & 23 & 0.71 & 73 & 27 & 0.39 & 51 & 49 & 0.44 & 61 & 39 \\
\hline$S$ & 2.1 & 91 & 9 & 2.2 & 91 & 9 & 1.0 & 80 & 20 & 1.3 & 83 & 17 \\
\hline$N$ & 5.4 & 64 & 36 & 5.5 & 62 & 38 & 3.8 & 45 & 55 & 4.3 & 50 & 50 \\
\hline$C$ & 119 & 11 & 89 & 117 & 10 & 90 & 110 & 6 & 94 & 127 & 6 & 94 \\
\hline
\end{tabular}

(TF) and (LF) represent the contribution percents of throughfall and litterfall to total annual input elements.

$\mathrm{S}=\mathrm{SO}_{4}-\mathrm{S}_{\text {Throughfall }}+\mathrm{St}_{\text {Litterfall }}$,

$\mathrm{N}=\left(\mathrm{NH}_{4}-\mathrm{N}+\mathrm{NO}_{3}-\mathrm{N}+\mathrm{N}_{\text {org }}-\mathrm{N}\right)_{\text {Throughfall }}+\mathrm{Nt}_{\text {Litterfall }}$

$\mathrm{C}=\mathrm{DOC}_{\text {Throughfall }}+\mathrm{Ct}_{\text {Litterfall }}$

\subsection{Forest floor and mineral soil}

\subsubsection{Soil $\mathrm{pH}\left(\mathrm{CaCl}_{2}\right)$}

For both plots, BDP and SDP, measured $\mathrm{pH}$ values indicated very acidic soil conditions, ranging between 2.6 to 3.1 in the organic layers and between 3.5 to below 4.2 in the mineral soils down to a $40 \mathrm{~cm}$ soil depth (Fig. 11a, b). As it would be expected, the $\mathrm{pH}$ values are higher in the mineral horizons than in the organic layers for both plots. However, the vertical increase of the $\mathrm{pH}$ values with soil depth was more pronounce in the SDP (2.6 - 4.2) compared with the BDP $(2.8-4.0)$. 
(a)

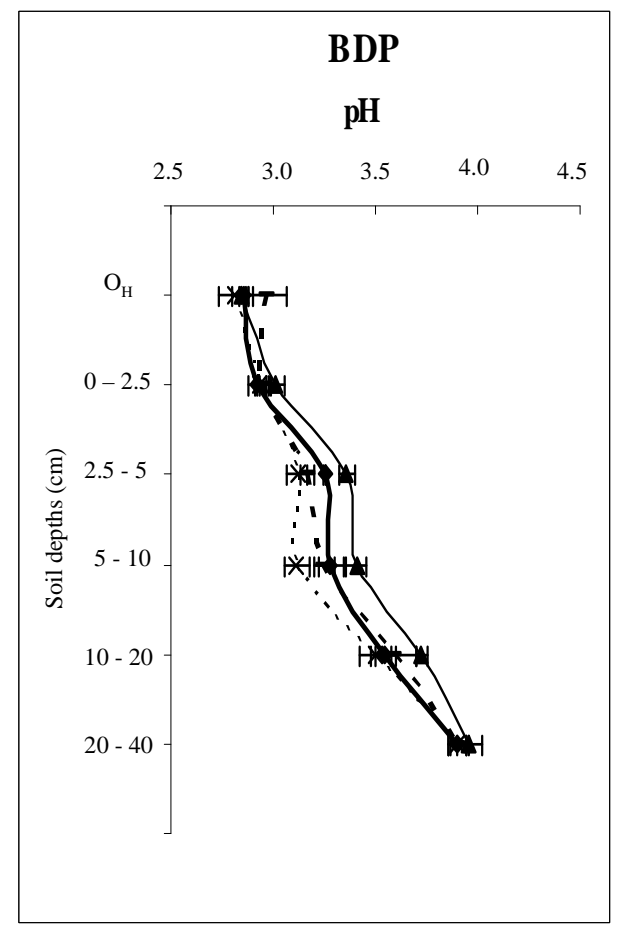

(b)

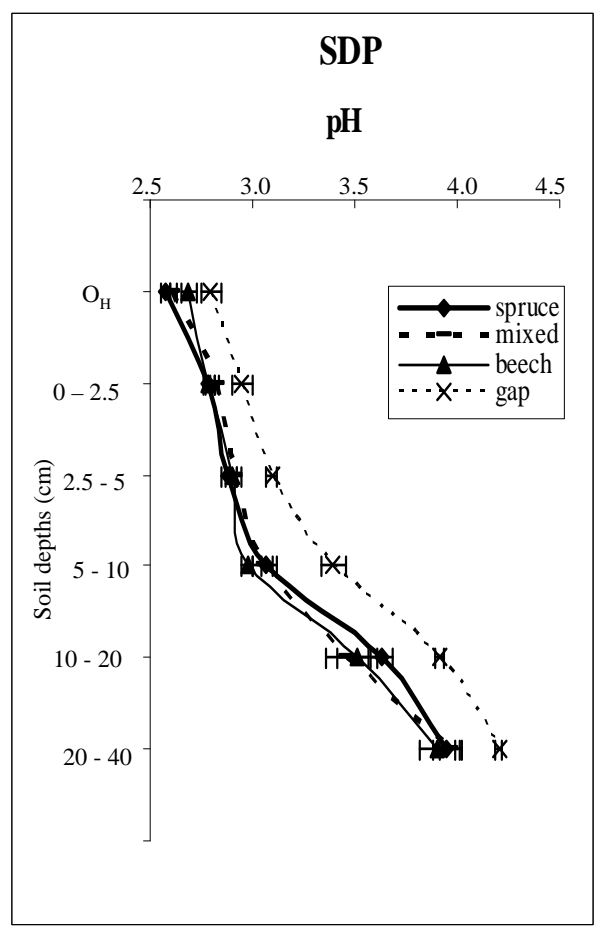

Fig. 11a, b: Vertical patterns of $\mathrm{pH}$ values from the $\mathrm{O}_{\mathrm{H}}$ layer down to the $40 \mathrm{~cm}$ soil depth in different sub-plots, (a) beech (BDP) and (b) spruce (SDP) dominated plot.

In the beech dominated plot (BDP) significantly higher $\mathrm{pH}$ values $(\mathrm{p}<0.05)$ were recorded in the top mineral soil in the beech sub-plot, compared with the spruce sub-plot. While in the spruce dominated plot (SDP) the gap sub-plots showed significantly higher $\mathrm{pH}$ values $(\mathrm{p}<0.05)$ in the organic and mineral soil layers (up to $40 \mathrm{~cm}$ depth), compare to other subplots.

\subsubsection{Concentration and storage of elements in the forest floor}

\section{Beech dominated plot (BDP)}

The concentration of $\mathrm{C}$ and $\mathrm{N}$ decreased with increasing soil depth (Tab. 9). In the $\mathrm{O}_{\mathrm{L}+\mathrm{F}}$ layer, carbon showed significantly higher concentration in the spruce sub-plot compare to the beech sub-plot. There were no significant differences in the $\mathrm{N}$ concentration among sub-plots in both organic layers $\left(\mathrm{O}_{\mathrm{L}+\mathrm{F}}, \mathrm{O}_{\mathrm{H}}\right)$ within the beech dominated plot. No significant differences were also found in $\mathrm{C} / \mathrm{N}$ ratios of the organic layers among different sub-plots. However, dry weights of $\mathrm{O}_{\mathrm{L}+\mathrm{F}}$ layers in the spruce subplot were significantly higher compared with the beech and gap subplots. 
The total concentration of potassium and aluminium in the $\mathrm{O}_{\mathrm{L}+\mathrm{F}}$ layer of the BDP in the beech sub-plot showed significantly higher values compare to the gap sub-plot. The lowest concentration of magnesium in $\mathrm{O}_{\mathrm{L}+\mathrm{F}}$ layer was found in the gap sub-plot. In the $\mathrm{O}_{\mathrm{H}}$ layer of the beech dominated plot, the only significant difference was found in the magnesium concentration between the spruce and gap sub-plots (Tab. 9).

Significantly higher $\mathrm{C}, \mathrm{N}$ and $\mathrm{S}$ storages were detected in the $\mathrm{O}_{\mathrm{L}+\mathrm{F}}$ layer of the spruce subplot, compared with the beech and gap sub-plots. The storages of carbon, nitrogen and sulphur followed the same order as the dry weights of organic matter in this layer (spruce $\geq$ mixed $\geq$ beech $\geq$ gap). No significant differences were found in the $\mathrm{C}$ and $\mathrm{N}$ pools among the $\mathrm{O}_{\mathrm{H}}$ layers of different sub-plots (Tab. 9). The whole organic layers $\left(\mathrm{O}_{\mathrm{L}+\mathrm{F}}\right.$ and $\left.\mathrm{O}_{\mathrm{H}}\right)$ showed higher total stocks of $\mathrm{C}$ and $\mathrm{N}$ in the spruce subplot, compared with the mixed subplot (Tab. 10).

The total storages of base cations and aluminium in the forest floor of different sub-plots followed the same order as dry weights of organic matter accumulated in the organic layers (spruce $\geq$ beech $\geq$ mixed $\geq$ gap). A significantly higher storage of potassium, magnesium, and aluminium was detected in the forest floors of the spruce and beech sub-plots, compared with the gap sub-plot (Tab. 10). 
Tab. 9: Mean $( \pm \mathrm{SD})$ characteristics of the organic layers under different canopy classes in the beech (BDP) and spruce (SDP) dominated plot.

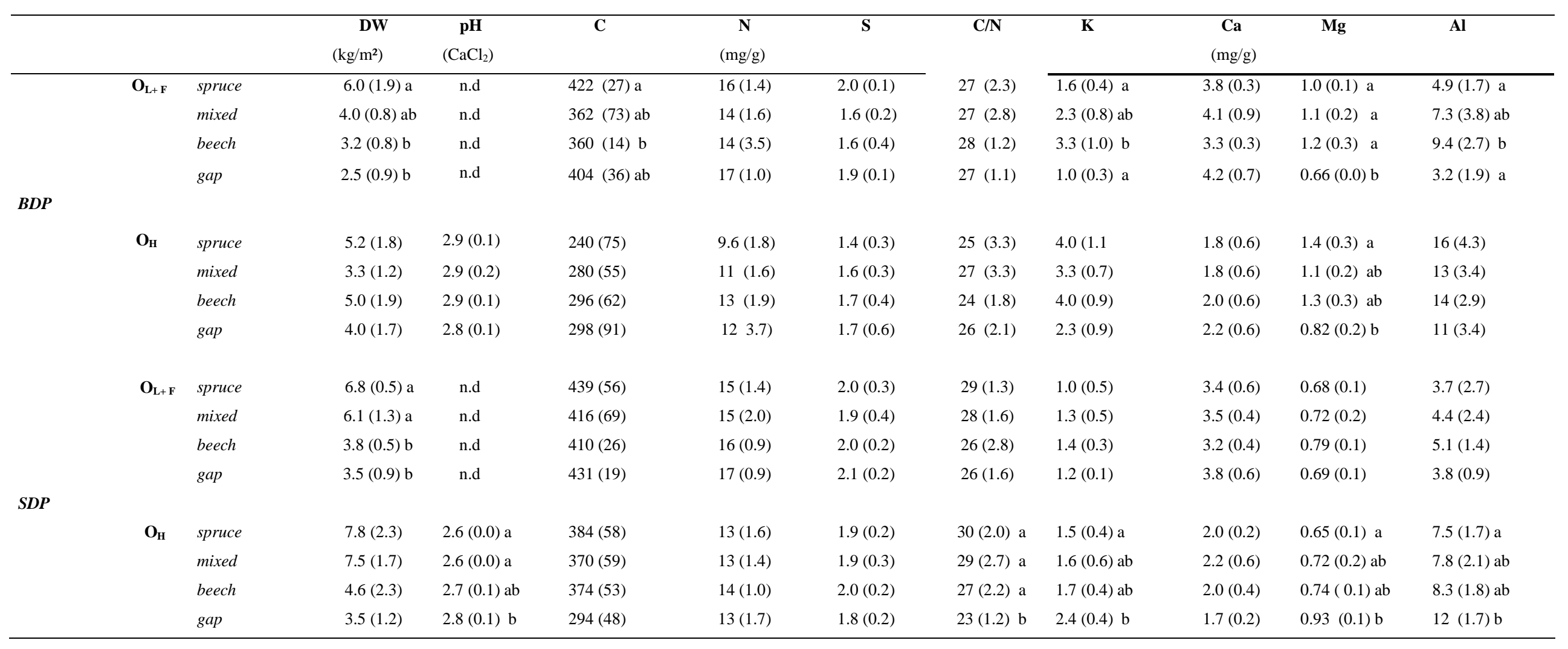

Different letters indicate significantly differences $(\mathrm{P}<0.05)$ between different subplots in each soil layer, n.d. $=$ no detected. 


\section{Spruce dominated plot (SDP)}

In the $\mathrm{O}_{\mathrm{L}+\mathrm{F}}$ layer, the concentration of carbon in the beech sub-plot was lower than in the gap and spruce sub-plots. No significant differences were found for the $\mathrm{N}$ concentrations in both organic layers $\left(\mathrm{O}_{\mathrm{L}+\mathrm{F}}\right.$ and $\left.\mathrm{O}_{\mathrm{H}}\right)$ among different sub-plots within SDP.

Tab. 10: Mean $( \pm S D)$ element storage in the organic layer $\left(\mathrm{O}_{\mathrm{L}+\mathrm{F}}\right.$ and $\left.\mathrm{O}_{\mathrm{H}}\right)$ in different sub-plots at the beech (BDP) and spruce (SDP) dominated plot.

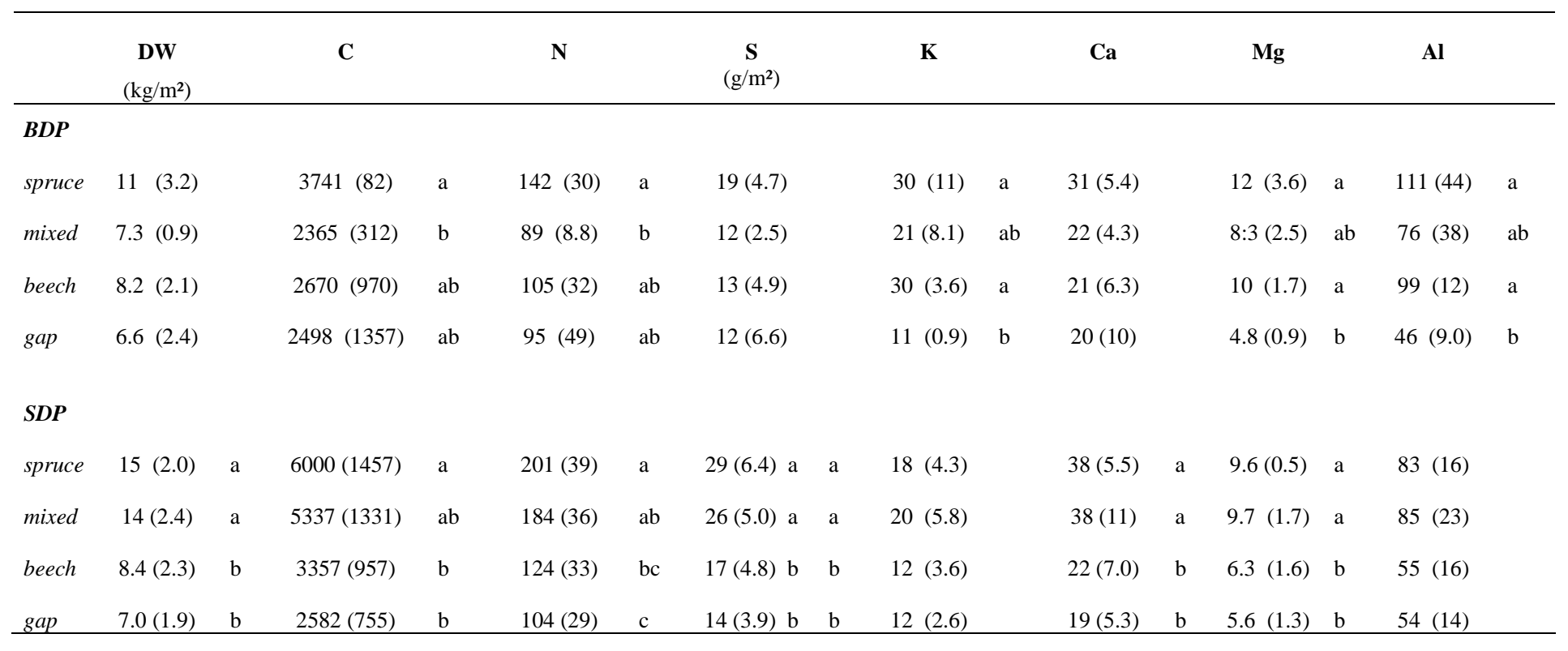

Different letters indicate significantly differences $(\mathrm{P}<0.05)$ between subplots

The gap sub-plot showed significantly lower $\mathrm{C} / \mathrm{N}$ ratios of $\mathrm{O}_{\mathrm{H}}$ layer compared with other subplots (Tab. 9). The average dry weight (mass) of organic matter in $\mathrm{O}_{\mathrm{L}+\mathrm{F}}$ layer showed significantly higher amounts in the spruce and mixed sub-plots, compare to the beech and gap sub-plots.

In the SDP, no differences were found in the concentration of all considered cations in the $\mathrm{O}_{\mathrm{L}+\mathrm{F}}$ layer among different sub-plots. However, in the $\mathrm{O}_{\mathrm{H}}$ layer potassium, magnesium and aluminium showed significantly higher concentrations in the gap sub-plot than in the spruce sub-plot.

The storage of $\mathrm{C}, \mathrm{N}$ and $\mathrm{S}$ in the $\mathrm{O}_{\mathrm{L}+\mathrm{F}}$ layer was higher in the spruce and mixed sub-plot, compared with the beech and gap sub-plot. For the $\mathrm{O}_{\mathrm{H}}$ layer significantly higher amounts of $\mathrm{C}, \mathrm{N}$ and $\mathrm{S}$ pools have been recorded for the spruce and mixed sub-plots compared to the gap sub-plot. The patterns of differences in the storage of $\mathrm{C}, \mathrm{N}$ and $\mathrm{S}$ in the forest floor 
approximately followed the differences in dry weight of the organic matter (spruce $\geq$ mixed $>$ beech $\geq$ gap)

In the forest floor, the storage of base cations and aluminium in each subplot followed the same order as total dry weights (Tab. 10). In the cases of calcium and magnesium significantly higher pools were recorded in the spruce and mixed sub-plots, compared with the beech and gap sub-plot.

\subsubsection{Concentration and storage elements in the mineral soil layers}

\section{Beech dominated plot (BDP)}

Concentrations of $\mathrm{C}$ and $\mathrm{N}$ showed no significant differences in different mineral soil layers among different sub-plots. The $\mathrm{C} / \mathrm{N}$ ratios were significantly higher in the gap, compared with the other sub-plots in the top $10 \mathrm{~cm}$ and also higher than in the beech sub-plot in the $10-20$ and 20-40 $\mathrm{cm}$ soil layers at this plot.

The cation exchange capacity (CEC) in all soil layers showed no significant differences among sub-plots. Base saturation (BS) tended to be higher in the gap, compared to other subplots in the top $10 \mathrm{~cm}$ of the mineral soil. The higher base saturation in the gap sub-plot compared to the other sub-plots was due to higher concentrations of exchangeable $\mathrm{Ca}^{2+}$ in BDP (Tab. 11).

Further results revealed significantly higher concentrations of exchangeable $\mathrm{K}^{+}$in the top 10 $\mathrm{cm}$ of the mineral soil layer under the beech canopy, compared to the spruce sub-plot. For exchangeable calcium, higher concentrations were recorded for the gap sub-plot, compared to the spruce sub-plot in the top $10 \mathrm{~cm}$ of the mineral soil.

The concentrations of exchangeable $\mathrm{Mg}^{2+}$ and $\mathrm{Al}^{3+}$ showed no significant differences in all mineral soil layers (Tab. 11). The percentage of exchangeable $\mathrm{Ca}^{2+}$ decreased with soil depth whereas the percentage of exchangeable $\mathrm{Al}^{3+}$ increased. A significantly negative relationship was found between $\mathrm{Ca}(\% \mathrm{CEC})$ and $\mathrm{Al}(\% \mathrm{CEC})$ in the mineral soil layers $\left(\mathrm{r}^{2}=-0.83\right.$, $P<0.05)$. 
Tab. 11: Mean $( \pm \mathrm{SD})$ characteristics of the mineral soil layers in different sub-plots in the beech (BDP) and spruce (SDP) dominated plot.

\begin{tabular}{|c|c|c|c|c|c|c|c|c|c|c|c|c|c|c|}
\hline & & & $\begin{array}{r}\text { DW } \\
\left(\mathrm{kg} / \mathrm{m}^{2}\right)\end{array}$ & $\begin{array}{c}\mathbf{p H} \\
\left(\mathrm{CaCl}_{2}\right) \\
\end{array}$ & C & $\mathbf{N}$ & $\mathbf{S}$ & $\mathbf{C} / \mathbf{N}$ & $\mathbf{K}$ & $\begin{array}{c}\text { Ca } \\
\left(\mathrm{mmol}_{\mathrm{c}} / \mathrm{kg}\right)\end{array}$ & Mg & Al & CEC & $\begin{array}{l}\text { BS } \\
(\%)\end{array}$ \\
\hline & $0-10$ & spruce & $69(2.1) \mathrm{a}$ & $3.1(0.1) a b$ & $33(6.0)$ & $1.7(0.2)$ & $0.26(0.04)$ & $19(1.0) \mathrm{a}$ & $1.4(0.2) \mathrm{a}$ & $4.7(1.0) \mathrm{a}$ & $1.6(0.3)$ & $68(1.6)$ & $101(4.7)$ & $7.2(1.1)$ \\
\hline & & mixed & $72(9.1) \mathrm{ab}$ & $3.1(0.1) \mathrm{ab}$ & 37 (3.6) & $2.0(0.2)$ & $0.28(0.02)$ & $18(1.3) \mathrm{a}$ & $1.6(0.2) \mathrm{ab}$ & $4.7(1.7) \mathrm{ab}$ & $2.0(0.4)$ & $69(3.9)$ & $101(4.7)$ & $7.9(1.8)$ \\
\hline & & beech & $82(5.7) b$ & $3.3(0.1) \mathrm{b}$ & $31(2.4)$ & $1.8(0.1)$ & $0.24(0.05)$ & $17(1.3) \mathrm{a}$ & $2.0(0.3) \mathrm{b}$ & $4.8(1.3) \mathrm{ab}$ & $1.5(0.1)$ & $73(4.6)$ & $100(4.5)$ & $8.0(1.0)$ \\
\hline & & Gap & $82(8.5) \mathrm{b}$ & $3.1(0.1) \mathrm{a}$ & $39(6.9)$ & $1.6(0.2)$ & $0.23(0.04)$ & $24(1.3) \mathrm{b}$ & $1.6(0.2) \mathrm{ab}$ & $7.5(1.4) \mathrm{b}$ & $1.4(0.4)$ & 54 (19) & $96 \quad(21)$ & $11 \quad(4.2)$ \\
\hline \multirow[t]{12}{*}{$B D P$} & $10-20$ & spruce & 78 (11) & $3.6(0.1)$ & $18(2.2)$ & $1.1(0.1)$ & $0.17(0.01)$ & $16(0.6) a b$ & $0.8 \quad(0.2)$ & $1.5(0.3)$ & $0.86(0.1)$ & $67(8.2)$ & $76(9.2)$ & $3.9(0.9)$ \\
\hline & & mixed & 77 (16) & $3.6(0.2)$ & $19(4.9)$ & $1.3(0.3)$ & $0.17(0.02)$ & $15(1.8) a b$ & $0.91(0.3)$ & $1.6(1.4)$ & $0.81(0.4)$ & $62(6.9)$ & $72(13)$ & $4.3(1.8)$ \\
\hline & & beech & $78(7.4)$ & $3.7(0.1)$ & $15(3.0)$ & $1.1(0.2)$ & $0.16(0.02)$ & $14(1.5) \mathrm{b}$ & $1.0 \quad(0.1)$ & $1.2(0.2)$ & $0.58(0.1)$ & $59(1.4)$ & $66(1.9)$ & $4.2(0.5)$ \\
\hline & & gap & $87(6.7)$ & $3.5(0.2)$ & $17(1.1)$ & $1.0(0.1)$ & $0.14(0.03)$ & $17(0.4) \mathrm{a}$ & $0.87(0.3)$ & $1.6(0.5)$ & $0.54(0.1)$ & $48(15)$ & $58(15)$ & $5.7(2.8)$ \\
\hline & $20-40$ & spruce & 155 (22) & $3.9(0.1)$ & $12(1.6)$ & $0.87(0.1)$ & \multirow{4}{*}{$\begin{array}{l}0.16(0.02) \\
0.14(0.01) \\
0.15(0.03) \\
0.14(0.02)\end{array}$} & $13(0.9)$ & $0.78(0.2)$ & $1.5(0.5)$ & $0.46(0.1)$ & $48(11)$ & $54(12)$ & $5.1(0.9)$ \\
\hline & & mixed & $155(27)$ & $3.9(0.1)$ & $11(2.1)$ & $0.92(0.2)$ & & $12(1.0)$ & $0.77(0.4)$ & 1.0 & $0.44(0.1)$ & $44(5.2)$ & $48(6.6)$ & $4.4(1.9)$ \\
\hline & & beech & $155(15)$ & $4.0(0.1)$ & $9.6(2.5)$ & $0.90(0.1)$ & & $11(1.9)$ & $0.80(0.1)$ & $0.80(0.2)$ & $0.36(0.1)$ & $44(9.8)$ & $48(10)$ & $4.3(0.9)$ \\
\hline & & gap & $174(13)$ & $3.9(0.1)$ & $11(1.5)$ & $0.80(0.0)$ & & $14(1.6)$ & $0.64(0.2)$ & $0.90(0.2)$ & $0.30(0.1)$ & $36(10)$ & $39(10)$ & $5.1(2.2)$ \\
\hline & $0-10$ & spruce & $75(1.0)$ & $3.0(0.1) \mathrm{a}$ & $41(4.3)$ & $1.9(0.2)$ & $0.28(0.03)$ & $22(1.0)$ & $0.98(0.2)$ & $5.6(2.2)$ & $1.6(0.3)$ & $53(4.8)$ & $97(6.6)$ & $8.1(2.4)$ \\
\hline & & mixed & $71(9.4)$ & $3.0(0.1) \mathrm{a}$ & $45(4.7)$ & $2.1(0.2)$ & $0.31(0.03)$ & $21(0.7)$ & $1.4(0.1)$ & $6.9(2.9)$ & $2.1(0.6)$ & $48(12)$ & $94(5.4)$ & $11(3.4)$ \\
\hline & & beech & $67(1.3)$ & $2.9(0.1) \mathrm{a}$ & $43(4.4)$ & $1.9(0.1)$ & $0.30(0.02)$ & $23(1.5)$ & $1.2(0.3)$ & $4.5(0.9)$ & $1.8(0.2)$ & $56(5.8)$ & $99(4.9)$ & $7.5(1.1)$ \\
\hline & & gap & $69(5.0)$ & $3.2(0.1) \mathrm{b}$ & $46(7.2)$ & $2.0(0.3)$ & $0.32(0.1)$ & $22(0.3)$ & $1.3(0.1)$ & 5.0 & $1.6(0.5)$ & $71(8.2)$ & $104(12)$ & $7.0(2.4)$ \\
\hline \multirow[t]{8}{*}{$S D P$} & $10-20$ & spruce & $89(9.4)$ & $3.6(0.1) \mathrm{a}$ & $19(2.5)$ & $1.1(0.2) \mathrm{a}$ & $0.18(0.01)$ & $17(1.0)$ & $0.56(0.1) \mathrm{ab}$ & $1.7(0.3)$ & $0.47(0.1)$ & $51(3.2)$ & $58(4.8)$ & $4.6(0.3)$ \\
\hline & & mixed & $78(7.8)$ & $3.5(0.2) \mathrm{a}$ & $24(3.0)$ & $1.3(0.1) \mathrm{b}$ & $0.20(0.02)$ & $18(1.2)$ & $0.77(0.2) \mathrm{b}$ & $2.7(1.4)$ & $0.87(0.3)$ & $53(6.4)$ & $66(5.7)$ & $6.5(2.6)$ \\
\hline & & beech & $79(9.9)$ & $3.5(0.2) \mathrm{a}$ & $21(2.5)$ & $1.1(0.1) \mathrm{a}$ & $0.18(0.02)$ & $19(2.4)$ & $0.65(0.2) \mathrm{ab}$ & $1.6(0.4)$ & $0.75(0.4)$ & $54(6.9)$ & $64(11)$ & $4.6(0.5)$ \\
\hline & & gap & $78(6.3)$ & $3.9(0.1) \mathrm{b}$ & $19(1.0)$ & $1.1(0.0) \mathrm{a}$ & $0.18(0.02)$ & $18(0.8)$ & $0.39(0.0) \mathrm{a}$ & $1.1(0.5)$ & $0.39(0.2)$ & $48(7.2)$ & $53(7.9)$ & $3.5(0.5)$ \\
\hline & $20-40$ & spruce & 178 (19) & $4.0(0.1)$ & $13(4.5)$ & $0.98(0.1)$ & $0.19(0.01)$ & $13(3.3)$ & $0.69(0.2)$ & $1.1(0.2)$ & $0.30(0.1)$ & $41(10)$ & $45(11)$ & $4.7(0.6)$ \\
\hline & & mixed & $160(13)$ & $4.0(0.1)$ & $18(5.0)$ & $1.1 \quad(0.2)$ & $0.19(0.01)$ & $16(2.2)$ & $0.60(0.3)$ & $1.7(0.7)$ & $0.46(0.3)$ & $39(4.9)$ & $44(6.1)$ & $6.0(2.0)$ \\
\hline & & beech & $159(20)$ & $3.9(0.2)$ & $15(2.6)$ & $0.96(0.1)$ & $0.17(0.02)$ & $16(2.3)$ & $0.62(0.1)$ & $1.1(0.3)$ & $0.39(0.2)$ & $43(7.9)$ & $47(9.6)$ & $4.5(0.5)$ \\
\hline & & gap & 157 (13) & $4.2(0.1)$ & $11(1.3)$ & $0.85(0.1)$ & $0.16(0.02)$ & $13(1.0)$ & $0.38(0.2)$ & $0.75(0.2)$ & $0.21(0.0)$ & $30(4.3)$ & $34(4.3)$ & $3.9(0.5)$ \\
\hline
\end{tabular}

$\mathrm{DW}=$ Dry weight $\mathrm{CEC}=$ Cation exchange capacity; Base saturation $(\mathrm{BS})=$ equivalent sum of exchangeable base cations $(\mathrm{Na}, \mathrm{K}, \mathrm{Ca}, \mathrm{Mg})$ as a percent of CEC. Different letters indicate significantly differences $(\mathrm{P}<0.05)$ between subplots in each soil layer. 
The dry weight (DW) of soil per unit area $\left(\mathrm{kg} / \mathrm{m}^{2}\right)$ was significantly different in $0-10 \mathrm{~cm}$ of the mineral soil layers with higher values in the beech and gap sub-plots, compared with the spruce sub-plot.

The highest storage of carbon and also exchangeable calcium in the top $10 \mathrm{~cm}$ of the mineral soil was found in the gap sub-plot, compare to all other sub-plots. The storages of exchangeable $\mathrm{K}^{+}, \mathrm{Mg}^{2+}$ and $\mathrm{Al}^{3+}$ did not differ significantly in mineral soil layers among different subplots in the beech dominated plot (Fig.12a).

The total storage of carbon in the mineral soil up to $40 \mathrm{~cm}$ soil depth was significantly higher in the gap compared with the spruce sub-plot. However, no further significantly differences were found in total storage of other elements in the mineral soil up to $40 \mathrm{~cm}$ soil depth of the BDP (Tab. 12).

\section{Spruce dominated plot (SDP)}

The concentration of $\mathrm{C}$ showed no differences in all mineral soil layers among different subplots. The only significant difference in the $\mathrm{N}$ concentration was found in the 10-20 cm depth of the mineral soil in the mixed sub-plot compare to other sub-plots (Tab. 11). No significant differences were found in dry weights and $\mathrm{C} / \mathrm{N}$ ratios in all mineral soil layers among different sub-plots in SDP.

The cation exchange capacity (CEC) in all soil layers showed no significant differences among different sub-plots. However, in SDP, base saturation (BS) in all soil layers of the mixed subplot tended to be higher compare to other sub-plots. Exchangeable potassium in the mixed subplot showed significantly higher concentrations compared with the spruce and gap sub-plots in 0-10 $\mathrm{cm}$ and 10-20 $\mathrm{cm}$ layers of the mineral soil, respectively. No differences were detected in the concentration of exchangeable $\mathrm{Ca}^{2+}, \mathrm{Mg}^{2+}$ and $\mathrm{Al}^{3+}$ in different mineral soil layers among sub-plots (Tab. 11). The percentage of exchangeable $\mathrm{Ca}^{2+}$ decrease with soil depth and showed a close negative correlation $\left(r^{2}=0.67, P<0.05\right)$ with the percentage of exchangeable Al. 

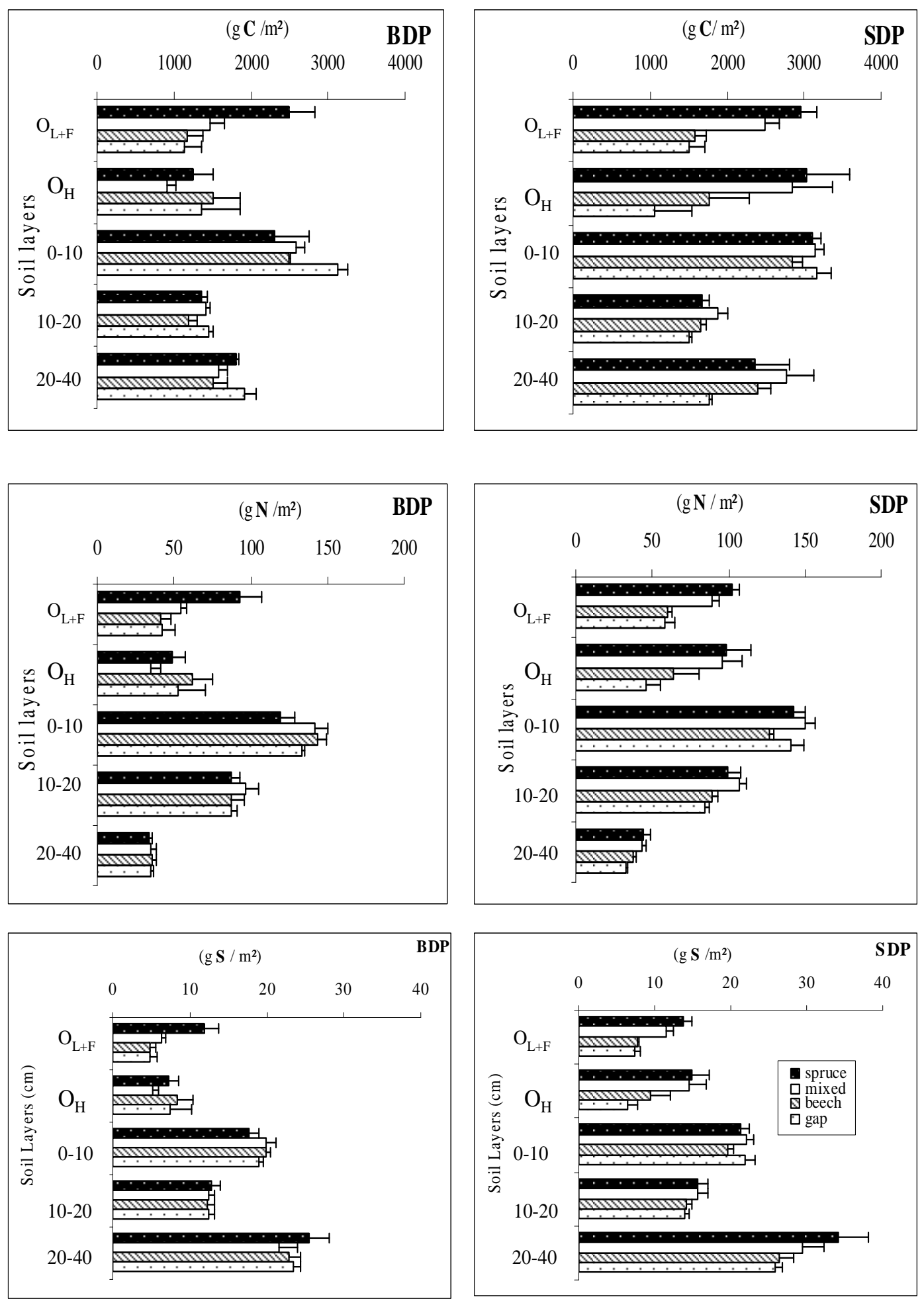

Fig.12a,b: Storage of $\mathrm{C}, \mathrm{N}, \mathrm{S}$ and cations $\left(\mathrm{K}^{+}, \mathrm{Ca}^{2+}, \mathrm{Mg}^{2+}\right.$ and $\left.\mathrm{Al}^{3+}\right)$ in the organic $\left(\mathrm{O}_{\mathrm{L}+\mathrm{F}}\right.$ and $\left.\mathrm{O}_{\mathrm{H}}\right)$ and the mineral soil layers $(0-40 \mathrm{~cm}$ depth) in different sub-plots of the (a) beech (BDP) and (b) spruce (SDP) dominated plot (continued on next page). 
(a)
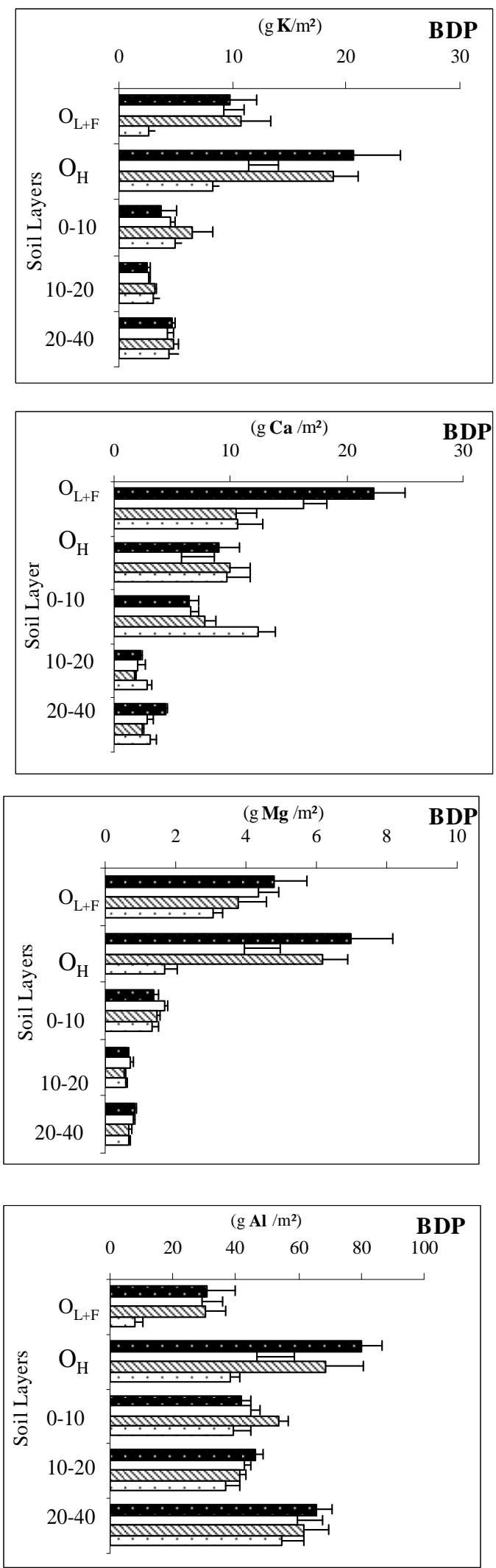

(b)
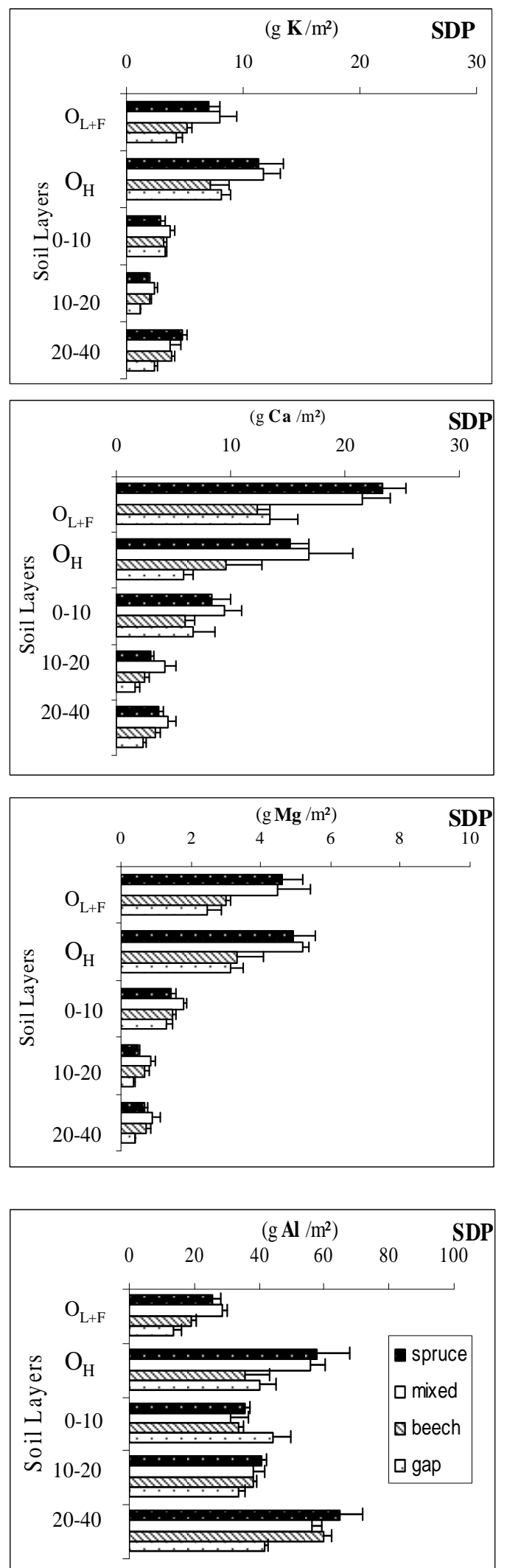

Fig.12a,b: Storage of $\mathrm{C}, \mathrm{N}, \mathrm{S}$ and cations $\left(\mathrm{K}^{+,} \mathrm{Ca}^{2+}, \mathrm{Mg}^{2+}\right.$ and $\left.\mathrm{Al}^{3+}\right)$ in the organic $\left(\mathrm{O}_{\mathrm{L}+\mathrm{F}}\right.$ and $\left.\mathrm{O}_{\mathrm{H}}\right)$ and the mineral soil layers $(0-40 \mathrm{~cm}$ depth) in different sub-plots of the (a) beech (BDP) and (b) spruce (SDP) dominated plot. 
The storage of exchangeable $\mathrm{K}^{+}$in $10-20 \mathrm{~cm}$ depth of mineral soil showed significantly higher values in the mixed sub-plot than in the gap sub-plot. In the $20-40 \mathrm{~cm}$ depth of the mineral soil, the storage of exchangeable potassium was higher in the spruce sub-plot, compare to the gap sub-plot. For $\mathrm{Ca}^{2+}$ and $\mathrm{Mg}^{2+}$ higher exchangeable pools were found in the 10-40 $\mathrm{cm}$ soil depth of the mixed sub-plot, compared with the gap sub-plot. The only significant difference in the exchangeable aluminium pool was recorded in 20-40 cm layer of the mineral soil with the lowest amounts in the gap sub-plot compare to other sub-plots (Fig. $12 b)$.

The differences in total storage of $\mathrm{C}, \mathrm{N}$ and exchangeable magnesium in the whole mineral soil (0 - $40 \mathrm{~cm}$ depth) showed significantly higher values in the mixed sub-plot, compared with the gap sub-plot (Tab. 12).

Tab. 12: Mean $( \pm \mathrm{SD})$ element storage in the mineral soil layer $(0-40 \mathrm{~cm}$ depth $)$ in different sub-plots of the beech (BDP) and spruce (SDP) dominated plot.

\begin{tabular}{|c|c|c|c|c|c|c|c|c|c|c|c|}
\hline & $\begin{array}{c}\text { DW } \\
\left(\mathrm{kg} / \mathrm{m}^{2}\right) \\
\end{array}$ & C & & $\mathbf{N}$ & & $\begin{array}{c}\mathbf{S} \\
\left(\mathrm{g} / \mathrm{m}^{2}\right) \\
\end{array}$ & $\mathbf{K}$ & $\mathrm{Ca}$ & Mg & & Al \\
\hline \multicolumn{12}{|l|}{$B D P$} \\
\hline spruce & 302 (34) & 5417 (529) & $a b$ & $340(35)$ & & $56(9.0)$ & $11(1.3)$ & 13 (1.6) & $2.9(0.2)$ & & 154 (14) \\
\hline mixed & $303(55)$ & $5566(350)$ & $a b$ & 377 (59) & & 54 (7.9) & $11(1.0)$ & $11(3.6)$ & $3.2(0.4)$ & & 147 (19) \\
\hline beech & 315 (27) & $5146(573)$ & $\mathrm{a}$ & $371(54)$ & & $55(5.8)$ & $15(2.4)$ & $12(2.0)$ & $2.7(0.3)$ & & 157 (24) \\
\hline gap & $342(28)$ & 6498 (596) & $\mathrm{b}$ & $359(23)$ & & $55(3.0)$ & $12(3.8)$ & $18(4.5)$ & $2.6(0.5)$ & & 131 (28) \\
\hline \multicolumn{12}{|l|}{$S D P$} \\
\hline spruce & 342 (28) & 7081 (688) & $a b$ & $416(42)$ & $a b$ & $71(11)$ & $9.5(1.5)$ & 15 & $2.6(0.1)$ & $a b$ & 141 (16) \\
\hline mixed & $310(30)$ & 7708 (782) & $\mathrm{a}$ & $426(29)$ & a & $67(8.4)$ & $9.9(2.8)$ & $19(6.6)$ & $3.5(0.8)$ & a & 125 (14) \\
\hline beech & 304 (30) & 6864 (617) & $a b$ & $366(24)$ & $a b$ & $60(5.5)$ & $8.9(0.9)$ & $12(2.4)$ & $2.9(0.5)$ & $a b$ & $132(5.0)$ \\
\hline gap & $304(18)$ & $6377(356)$ & $\mathrm{b}$ & $356(13)$ & $\mathrm{b}$ & $61(4.2)$ & $6.9(0.6)$ & $11(5.0)$ & $2.1(0.4)$ & $\mathrm{b}$ & $119(6.0)$ \\
\hline
\end{tabular}




\subsection{Soil solution:}

\subsubsection{Soil solution $\mathrm{pH}$}

The $\mathrm{pH}$ of soil solution at $10 \mathrm{~cm}$ depth of mineral soil showed significant differences between different sub-plots. The $\mathrm{pH}$ values ranged from 4.10 to 4.50 in the BDP and SDP. The patterns of $\mathrm{pH}$ values in the soil solution $\mathrm{pH}(10 \mathrm{~cm})$ followed the same order (beech $\geq \mathrm{gap} \geq$ mixed > spruce) in both plots (Fig. 13). The beech sub-plots showed significantly higher pH values, compared with the spruce sub-plots. The mixed and gap sub-plots showed no significant differences in the soil solution $\mathrm{pH}$ at $10 \mathrm{~cm}$ depth of mineral soil in both plots. At $100 \mathrm{~cm}$ depth, $\mathrm{pH}$ values of the soil solution rose in both plots above 4.2, however no detectable differences were observed among different sub-plots within each plot (Tab.13).

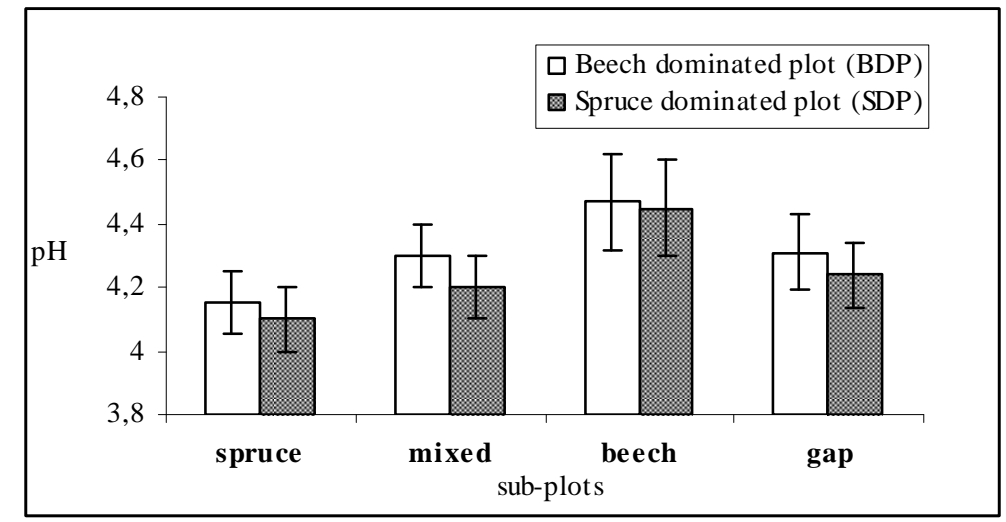

Fig. 13: Mean $\mathrm{pH}$ values $( \pm \mathrm{SD})$ of the soil solution (from $10 \mathrm{~cm}$ soil depth) in different sub-plots of the beech (BDP) and spruce (SDP) dominated plot.

\subsubsection{Ion concentrations}

Tab. 13 shows the chemical properties of soil solution at 10 and $100 \mathrm{~cm}$ depths of the mineral soil in different sub-plots of the beech (BDP) and spruce (SDP) dominated plot. Given values are the statistical mean of the ion concentration in the soil solution in the period from Oct. 2003 to July 2006. In both plots, $\mathrm{Ca}^{2+}$ and $\mathrm{K}^{+}$were the dominated cations, whereas $\mathrm{Cl}^{-}, \mathrm{NO}_{3}^{-}$ and $\mathrm{SO}_{4}{ }^{2-}$ were the dominated anions.

In the BDP, the concentration of $\mathrm{K}^{+}$in the soil solution at $10 \mathrm{~cm}$ depth of the mineral soil was significantly higher in the spruce and beech sub-plots, compared to the gap sub-plot. Analyses of variance (ANOVA) showed no significant differences in the concentration of other measured cations and anions in soil solution of $10 \mathrm{~cm}$ depth in this plot. The BC/Al molar ratio was significantly higher in the beech subplot, compared with the gap sub-plot. 
At $100 \mathrm{~cm}$ depth, the concentration of $\mathrm{K}^{+}$was significantly higher in the spruce sub-plot, compared with the other sub-plots. $\mathrm{Ca}^{2+}$ showed higher concentration of soil solution at 100 $\mathrm{cm}$ depth of mineral soil in the spruce and gap sub-plots, compared with the mixed and beech sub-plots in the beech dominated plot. The spruce sub-plot showed significantly higher concentration of $\mathrm{SO}_{4}{ }^{-2}$ compared to the gap sub-plot. The concentration of nitrate in $100 \mathrm{~cm}$ soil depth in the gap sub-plot tended to be higher than in the other sub-plots of the beech dominated plot (BDP).

In the SDP, potassium showed significantly higher concentration in the soil solution at $10 \mathrm{~cm}$ soil depth in the mixed sub-plot, compared with the beech and gap sub-plots. Higher concentrations of $\mathrm{Ca}^{2+}$ were recorded in the soil solution in the mixed sub-plot, compared with the beech sub-plot at $10 \mathrm{~cm}$ soil depth. In the spruce dominated plot, the significantly higher $\mathrm{SO}_{4}{ }^{2-}-\mathrm{S}$ concentrations were observed in the spruce and mixed sub-plots, compared to the beech and gap sub-plots. The molar ratio of BC/Al was significantly higher in the mixed sub-plot, compared with the beech and gap subplots.

The soil solution at $100 \mathrm{~cm}$ soil depth showed significantly higher concentrations of $\mathrm{K}^{+}$in the spruce and mixed canopy sub-plots, compared with the beech sub-plot. The concentration of $\mathrm{Ca}^{2+}$ in this depth was significantly lower in the beech sub-plot, compared to the other subplots. Nitrate concentration in the seepage water (at $100 \mathrm{~cm}$ ) of the gap sub-plot tended to be higher compared with the other sub-plots in the spruce dominated plot (SDP). 
Tab. 13: Mean $( \pm \mathrm{SD})$ element concentrations and molar ratios of $\mathrm{BC} / \mathrm{Al}$ in the soil solution at 10 and $100 \mathrm{~cm}$ soil depths in different sub-plots of the beech (BDP) and spruce (SDP) dominated plot, sampled in the period from Oct 2003 to July 2006.

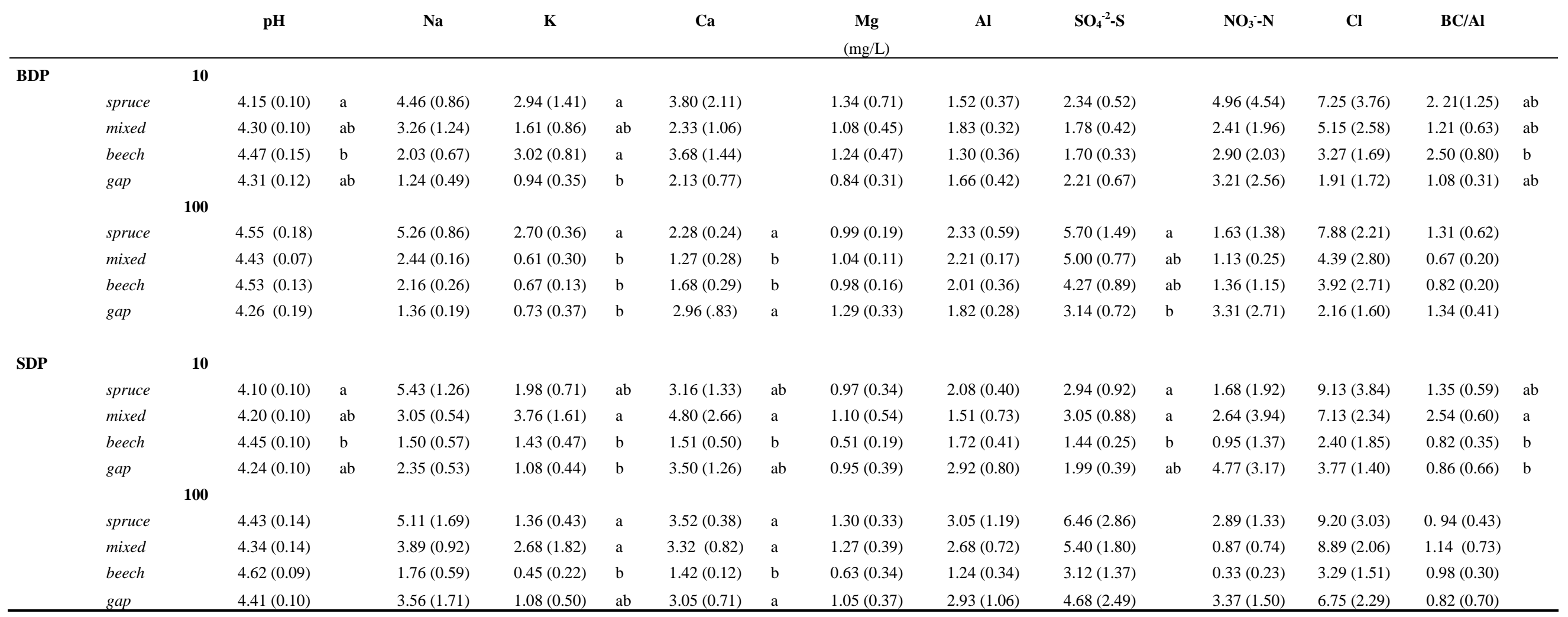

Different letters indicate significantly differences $(\mathrm{P}<0.05)$ between sub-plots in each depth. 


\subsection{Litter decomposition and nitrogen turnover}

4.4.1 Decay rate, remaining mass and carbon in decomposing needle litter

After a 15 months period of in situ incubation, needles showed only little visible breakdown and could still be identified, despite losing about half of their weight. Changes in the colour of decomposing litter were most pronounced in the litterbags incubated in the gap and under the beech canopy classes of both plots.

In all sub-plots, the remaining mass (Fig. 14a, b) and the decomposition rates (Fig. 16a, b) of decomposing needle litter decreased with increasing incubation time. As given in Tab. 14, no significant differences were found for the mean annual values of the decay rates ( $k$ constant) among different sub-plots $(\mathrm{n}=10, \mathrm{p}<0.05)$. An exponential function was applied to describe the relationship between the $k$ constant and the time of needle decomposition (Tab. 14).

Tab. 14: Mean $( \pm \mathrm{SD})$ annual decomposition rate $(k, \mathrm{n}=10$, for 12 months of in situ incubation) and the correlation coefficient between the $k$ constant and the time of needle decomposition ( $\mathrm{n}=75$, for 15 months) in different sub-plots of the beech (BDP) and spruce (SDP) dominated plot.

\begin{tabular}{llll}
\hline & subplot & $k \pm \mathrm{SD}$ & $r^{2}$ \\
\hline BDP & spruce & $0.73 \pm 0.23 \mathrm{a}$ & 0.83 \\
& mixed & $0.76 \pm 0.22 \mathrm{ab}$ & 0.82 \\
& beech & $0.78 \pm 0.22 \mathrm{~b}$ & 0.58 \\
& gap & $0.80 \pm 0.21 \mathrm{~b}$ & 0.75 \\
SDP & & & \\
& spruce & $0.79 \pm 0.20$ & 0.82 \\
& mixed & $0.76 \pm 0.26$ & 0.79 \\
& beech & $0.79 \pm 0.24$ & 0.86 \\
& gap & $0.79 \pm 0.22$ & 0.77 \\
\hline
\end{tabular}

At the end of the incubation period, the remaining mass of needles in different sub-plots ranged from $47 \%$ to $63 \%$ and from $58 \%$ to $63 \%$ of the initial mass in the BDP and SDP, respectively. Significant differences in the remaining mass of decomposing litter were observed in the last two months of incubation period only in the beech dominated plot. After about one year of the litterbag incubation, the remaining mass of decomposing needle was significantly higher in the spruce sub-plot compared with the beech and gap sub-plots in BDP (Fig. 14a, b). 
(a)

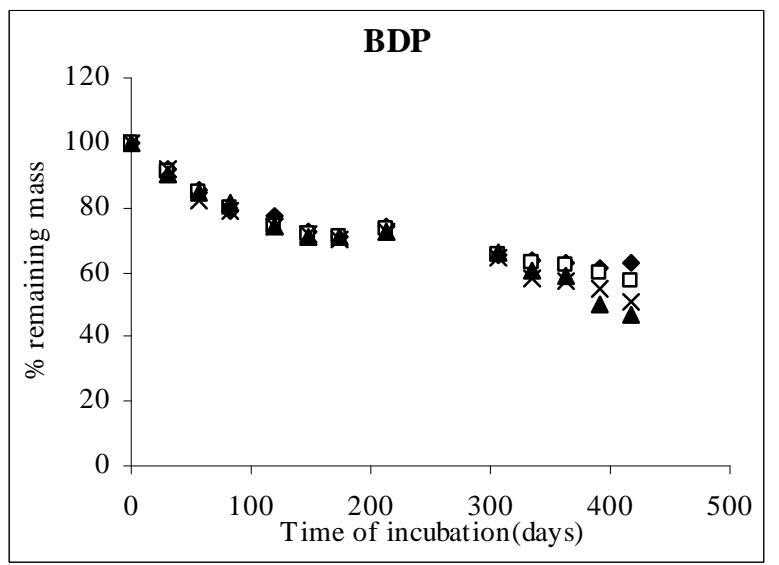

(b)

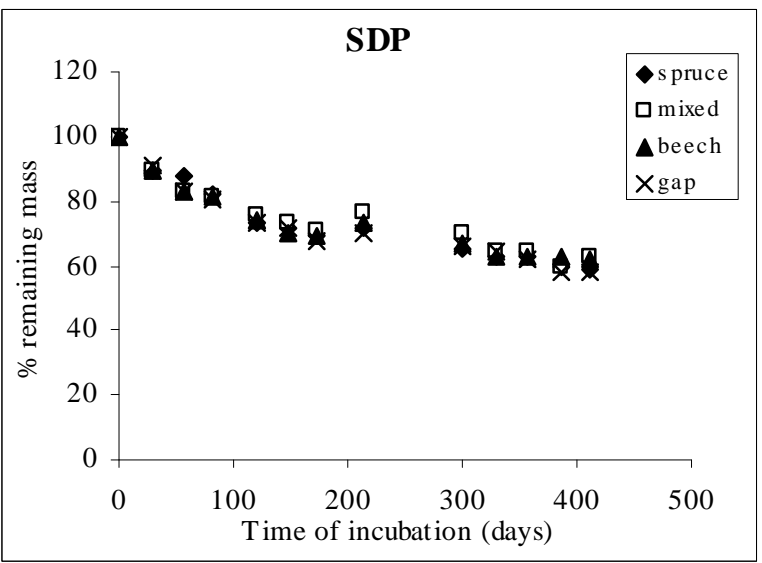

Fig. 14a,b: Percentage of remaining to initial mass during the decomposition of needle litter incubated in different sub-plots of the (a) beech (BDP) and (b) spruce (SDP) dominated plot from May 2005 to July 2006.

As given in Fig. 16 a, b, the temporal variation of the decomposition rates (k constant) showed two different phases during the incubation period. In the first phase a consistently decline of decomposition rates with time were observed until 10 months in both plots. In the second phase, the decomposition rates remain constant in all sub-plots in SDP, and only in the mixed subplot in BDP. In BDP, the decomposition rates in the beech and gap sub-plots after a short constant phase ( 3 months) started to increase but in the spruce sub-plot, it began to decrease. The significantly higher $k$ constants were observed in the beech and gap sub-plots compare to the spruce sub-plot in the last two months of the incubation period in beech dominated plot (BDP).

The variation of $\mathrm{C}$ concentrations was very low and showed no significant differences during the entire decomposition period. Hence, the temporal changes in decay rates ( $k$ constant) corresponded to changes in the percent of remaining $\mathrm{C}$ in litterbags during the incubation period in both plots (Fig. 15 and 16a, b). 
(a)

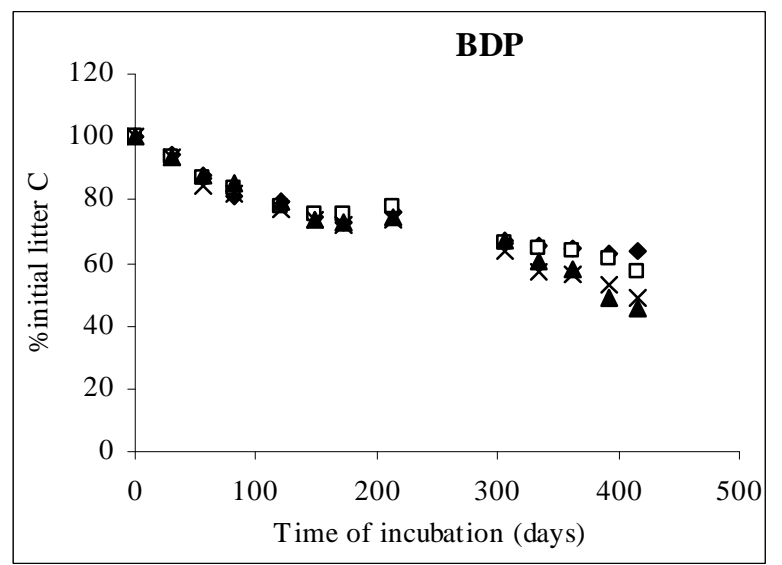

(b)

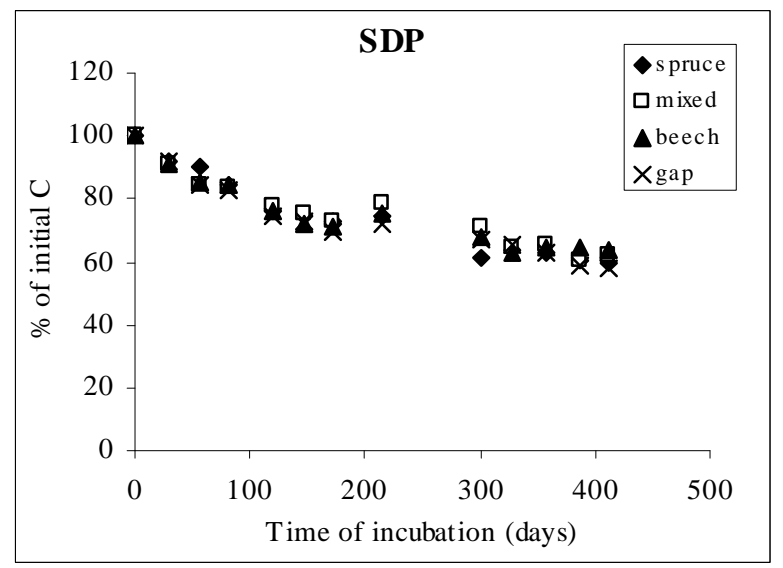

Fig. 15a,b: Changes of the percentages of remaining to initial carbon of decomposing needle litter after the incubation in different sub-plots of the (a) beech (BDP) and (b) spruce (SDP) dominated plot from May 2005 to July 2006.

(a)

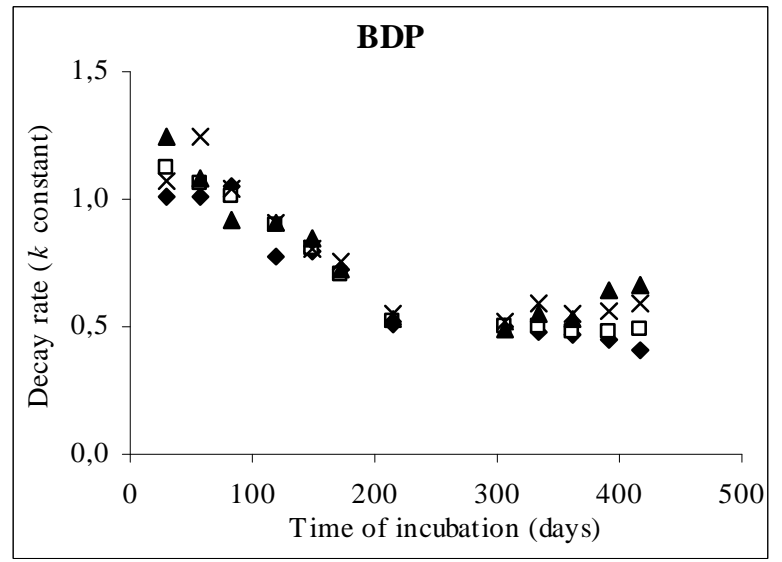

(b)

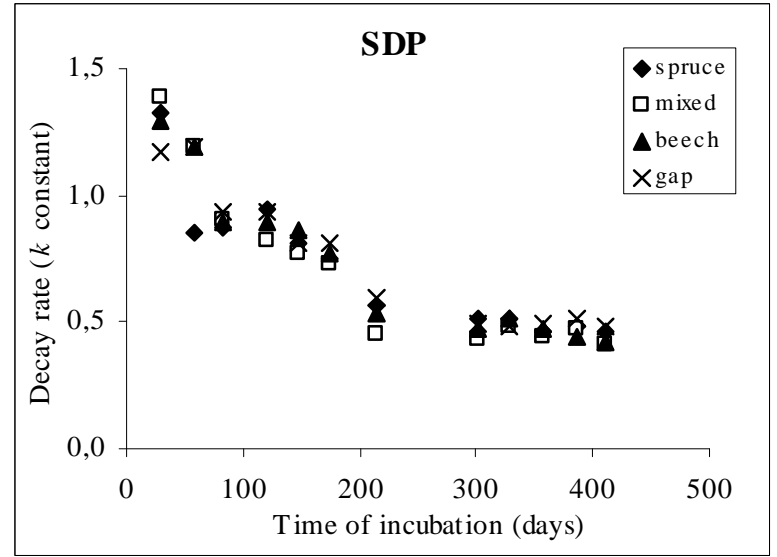

Fig. 16a,b: Changes in the decomposition rate (k constant) of decomposing needle litter after the incubation in different sub-plots of the (a) beech (BDP) and (b) spruce (SDP) dominated plot from May 2005 to July 2006.

\subsubsection{N dynamics in decomposing needle litter}

In both plots the total nitrogen concentration of decomposing needle litter increased sharply during the period of the litterbag incubation (Fig.17a, b). The increase in the concentration of total $\mathrm{N}$ was linearly correlated with decomposition time in both plots $\left(\mathrm{r}^{2}=0.82\right.$ for BDP and $\mathrm{r}^{2}=0.80$ for SDP). 
(a)

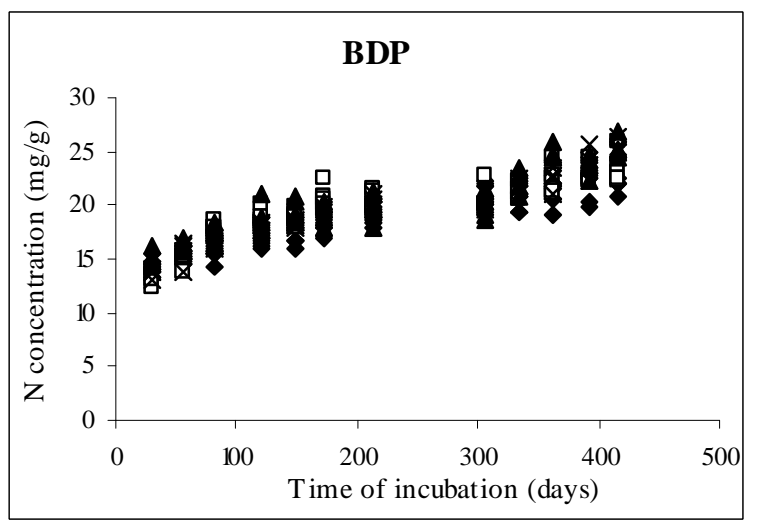

(b)

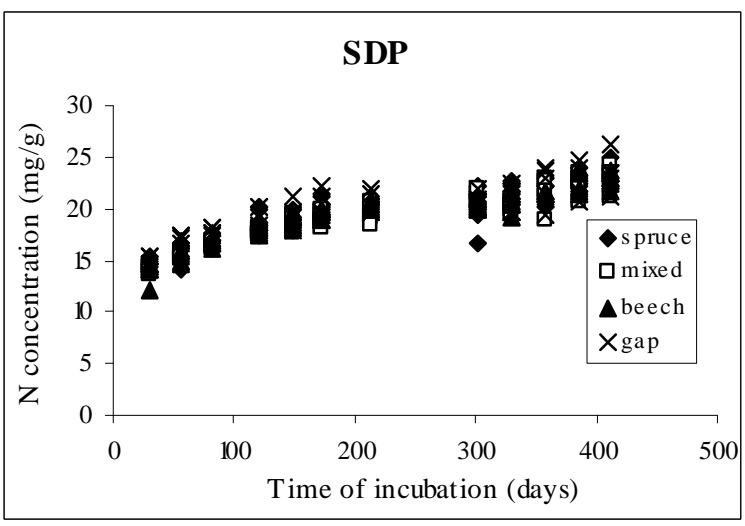

Fig. 17a,b: Relation between $\mathrm{N}$ concentration of decomposing needle litter and the time of litterbag incubation in different sub-plots of the (a) beech (BDP) and (b) spruce (SDP) dominated plot.

Fig.18a, $\mathrm{b}$ shows the temporal variation of $\mathrm{N}$ dynamics in the decomposing needle in different subplots at both plots. An accumulation of nitrogen was observed during the initial stage of litter decomposition in both plots. The nitrogen accumulation phase in all sub-plots, with the exceptions of the beech sub-plot in the BDP and the gap sub-plot in the SDP, was delayed due to a net release of $\mathrm{N}$. The net initially leaching phase was about 1- 2 months in all cases and only in the spruce sub-plot in BDP it lasted about 5 months.

In contrast to the increase in total litter $\mathrm{N}$ concentration, the ${ }^{15} \mathrm{~N}$ excess decreased with the incubation time in both plots. During the decomposition of needle litter, $\mathrm{N}$ incorporation from different external sources (fungal, throughfall and soil $\mathrm{N}$ ) simultaneously took place with releasing of litter $\mathrm{N}$. The temporal variation of $\mathrm{N}$ incorporation in all subplots followed the same pattern with no significant differences. The amounts of incorporated $\mathrm{N}$ within the incubated litterbags was not more than $20 \%$ of initial $\mathrm{N}$ 
(a)
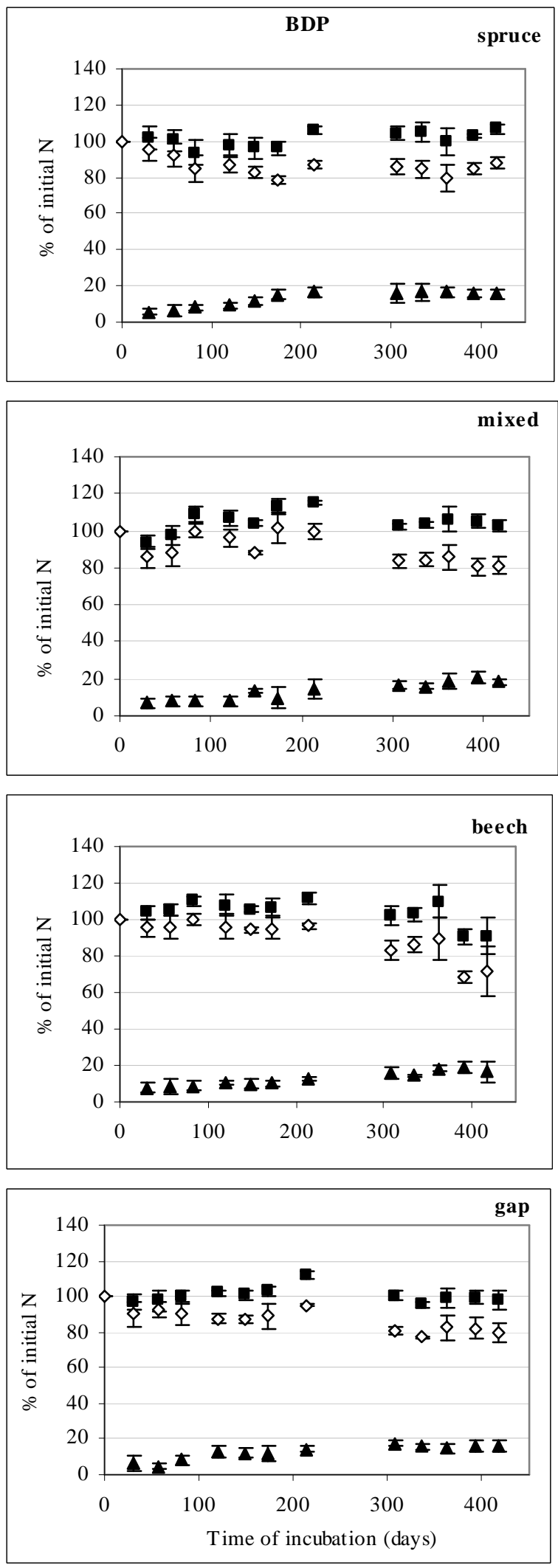

(b)
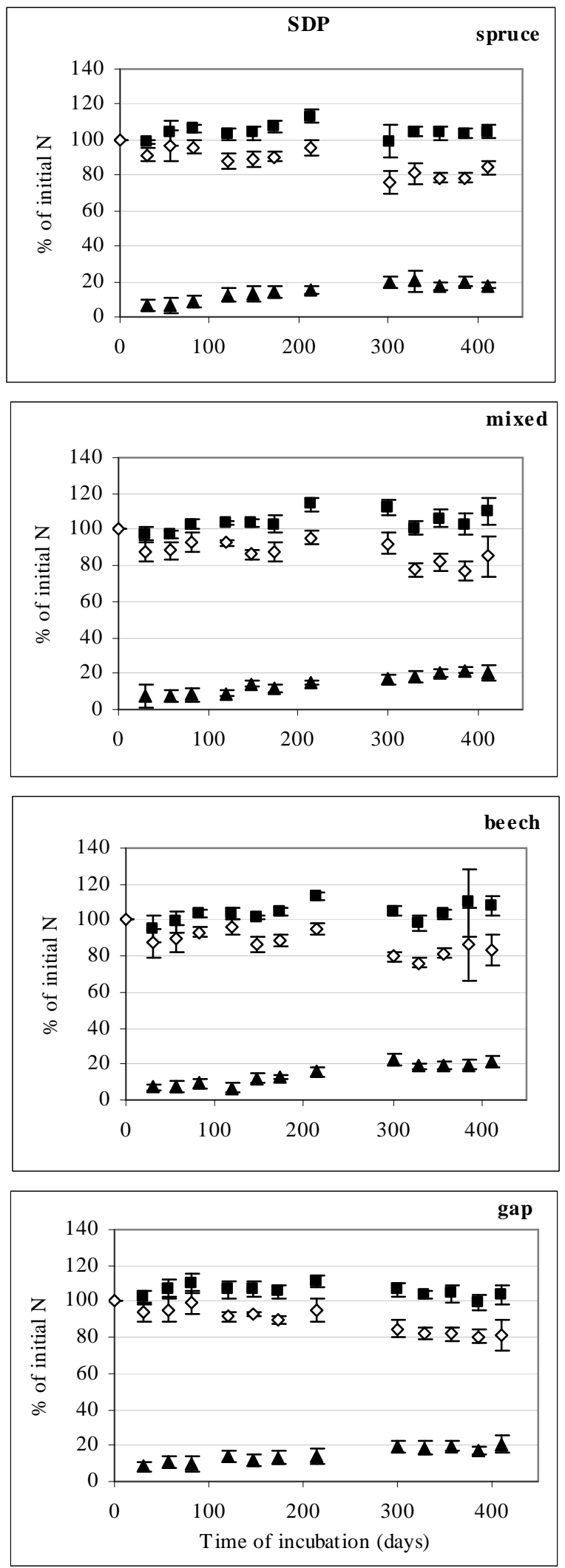

Fig. 18a,b: Temporal variation of total $N(\boldsymbol{\square}), \mathrm{N}$ release $(\diamond)$ and $\mathrm{N}$ incorporation $(\boldsymbol{\Delta})$ in the decomposing litter after the incubation in different sub-plots of the (a) beech (BDP) and (b) spruce (SDP) dominated plot from May 2005 to July 2006. Erorr bars indicate standard error deviation of the mean $( \pm \mathrm{SD}, \mathrm{n}=5)$. 
Fig.19a, b shows the temporal variation of the $\mathrm{C} / \mathrm{N}$ ratio of decomposing needles in different subplots at both plots. In all subplots the $\mathrm{C} / \mathrm{N}$ ratios showed a similar trend. In BDP, the spruce subplot showed significantly higher $\mathrm{C} / \mathrm{N}$ ratio during the incubation period compared with the beech and gap subplots.

(a)

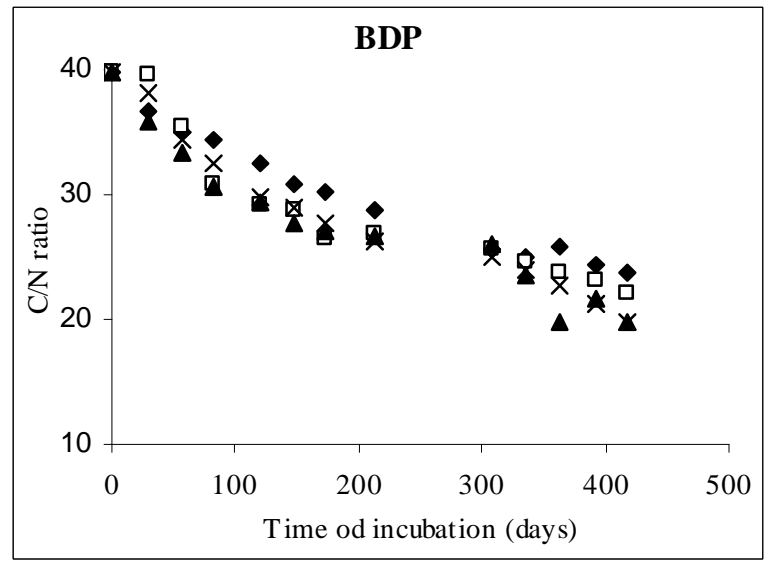

(b)

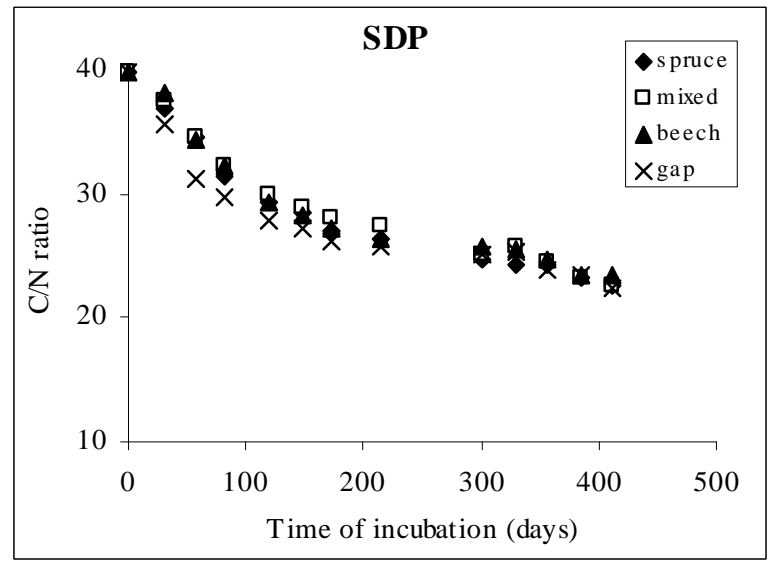

Fig. 19a,b: Changes in $\mathrm{C} / \mathrm{N}$ ratios of decomposing needle litter during the period of litterbag incubation (May 2005 to July 2006) within the forest floor in different sub-plots of the (a) beech (BDP) and (b) spruce (SDP) dominated plot.

\subsection{Soil respiration}

The average rates of soil respiration during the entire period of this investigation (from June 2005 to July 2006) ranged between $14.8-97.5 \mathrm{mg} \mathrm{C} \cdot \mathrm{m}^{-2} \cdot \mathrm{h}^{-1}$ in the BDP and $18.4-100.3 \mathrm{mg}$ C. $\mathrm{m}^{-2} \cdot \mathrm{h}^{-1}$ in the SDP (Tab. 15).

A significant difference in soil respiration rate was found in the beech dominated plot (BDP). In this plot, the beech sub-plot showed significantly $(\mathrm{P}<0.05)$ higher respiration rate compared with the gap sub-plot (Tab 15). In the spruce dominated plot (SDP) no significant differences were found in soil respiration rates among different sub-plots. 
Tab. 15: Mean rates of soil respiration, annual soil respiration $\left(S_{\text {res }}\right)$, annual $C$ inputs via foliar litterfall $\left(\mathrm{C}_{\text {lit }}\right)$, root-associated $\mathrm{CO}_{2}$ production $\left(\mathrm{R}_{\mathrm{res}}\right)$ and $\mathrm{R}_{\mathrm{res}} / \mathrm{S}_{\text {res }}$ ratios in different sub-plots of the beech (BDP) and spruce (SDP) dominated plot.

\begin{tabular}{|c|c|c|c|c|c|c|}
\hline Plot & subplot & $\begin{array}{l}\quad \text { Soil } \\
\text { respiration rate } \\
\left(\mathrm{mg} \mathrm{C} / \mathrm{m}^{2} . \mathrm{h}\right)\end{array}$ & $\mathrm{S}_{\mathrm{res}}\left(\mathrm{gC} / \mathrm{m}^{2}\right.$.year $)$ & $\mathrm{C}_{\text {lit }}\left(\mathrm{g} \mathrm{C} / \mathrm{m}^{2}\right.$.year $)$ & $\mathrm{R}_{\text {res }}\left(\mathrm{g} \mathrm{C} / \mathrm{m}^{2}\right.$.year $)$ & $\mathrm{R}_{\mathrm{res}} / \mathrm{S}_{\mathrm{res}}$ \\
\hline \multirow{4}{*}{$B D P$} & spruce & $44.4 \mathrm{ab}$ & $271 \mathrm{ab}$ & 157 & 115 & 0.42 \\
\hline & mixed & $51.0 \mathrm{ab}$ & $319 a b$ & 162 & 157 & 0.49 \\
\hline & beech & $63.5 \mathrm{a}$ & 395 a & 164 & 231 & 0.59 \\
\hline & gap & $35.0 \mathrm{~b}$ & $211 \mathrm{~b}$ & 160 & 51 & 0.24 \\
\hline \multirow[t]{4}{*}{$S D P$} & spruce & 53.7 & 337 & 106 & 232 & 0.69 \\
\hline & mixed & 53.1 & 339 & 105 & 234 & 0.69 \\
\hline & beech & 49.4 & 296 & 103 & 193 & 0.65 \\
\hline & gap & 45.2 & 279 & 119 & 160 & 0.57 \\
\hline
\end{tabular}

There were no significant differences in mean soil and forest floor temperatures among different subplots in both plots. Temporal trends of soil respiration followed approximately the same order as temporal changes in the mean soil temperature at $10 \mathrm{~cm}$ depth (Fig. 21 and 22a, b). The lowest rates of soil respiration were observed in November and March in both plots. Soil temperature (10 cm depth) explained $46 \%$ and $49 \%$ of $\mathrm{CO}_{2}$ released from the soil in BDP and SDP respectively (Fig. 23a, b).

(a)

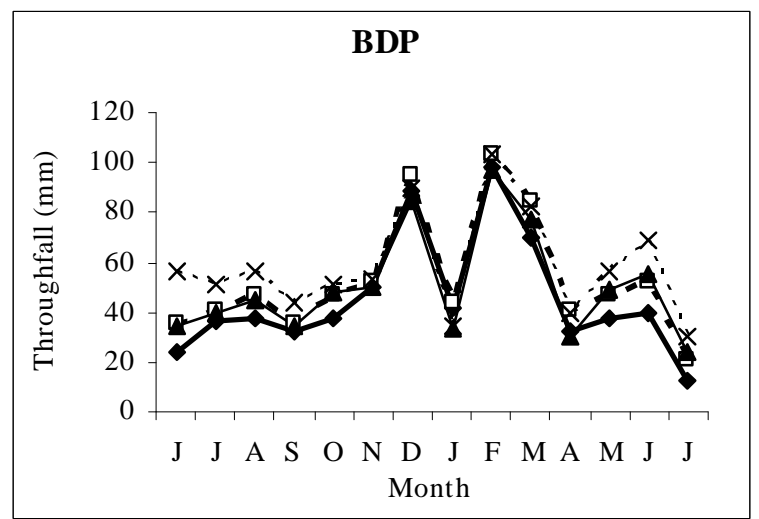

(b)

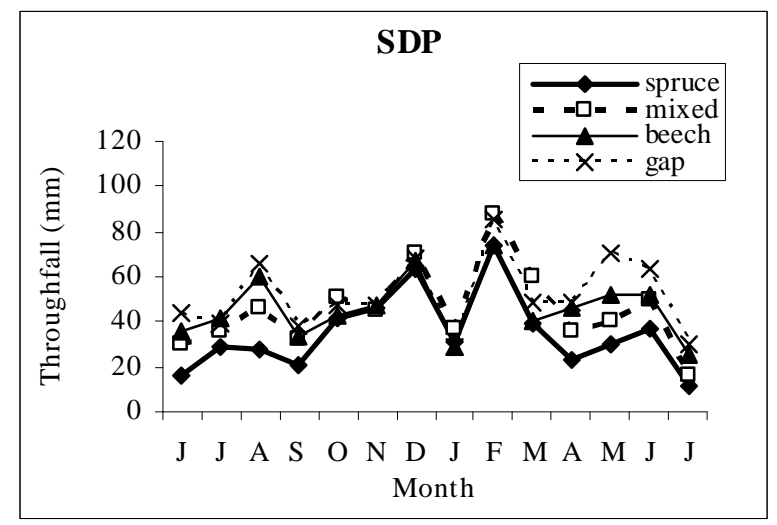

Fig. 20a,b: Mean monthly water flux via throughfall $(\mathrm{mm})$ in the different sub-plots of the a) beech (BDP) and b) spruce (SDP) dominated plot from June 2005 to July 2006. 
(a)

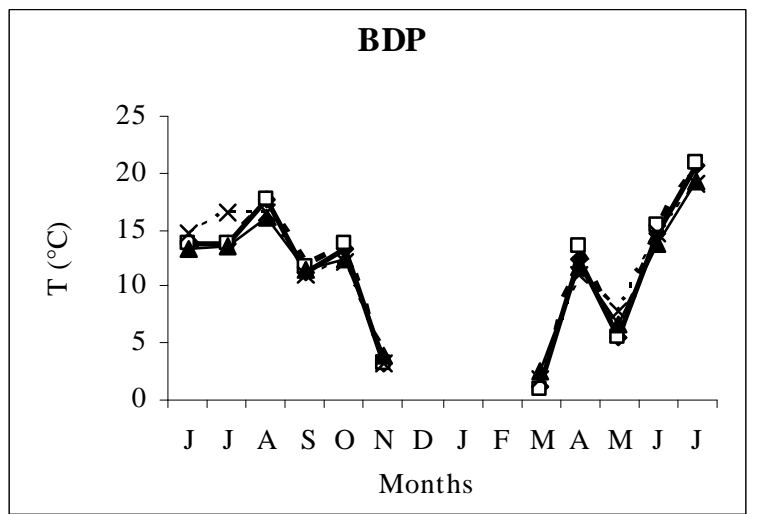

(b)

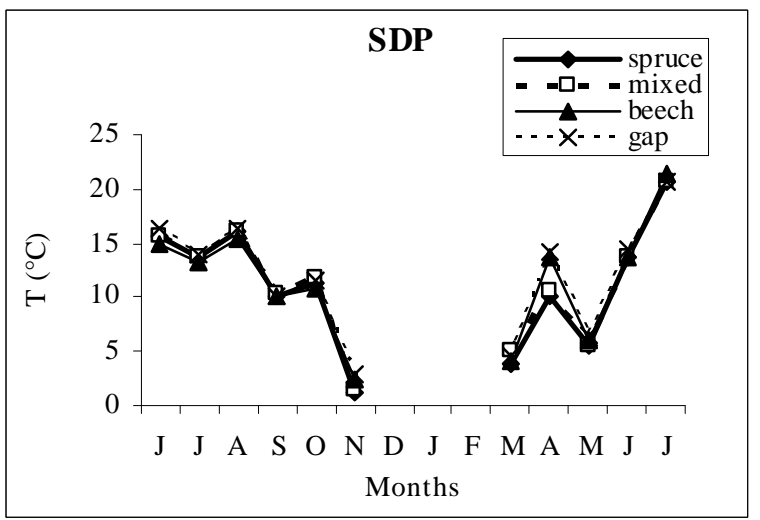

Fig. 21a,b: Temporal variation of mean soil temperatures $\left({ }^{\circ} \mathrm{C}\right)$ at $10 \mathrm{~cm}$ depth in different sub-plots of the a) beech (BDP) and b) spruce (SDP) dominated plot from June 2005 to July 2006.

(a)

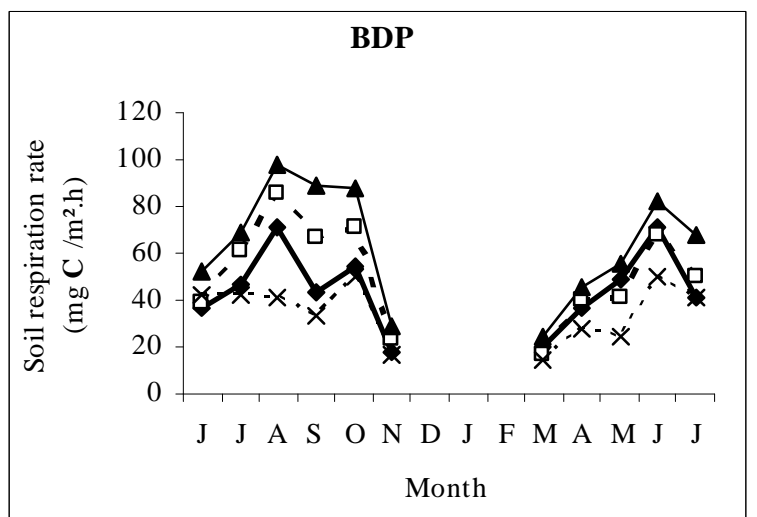

(b)

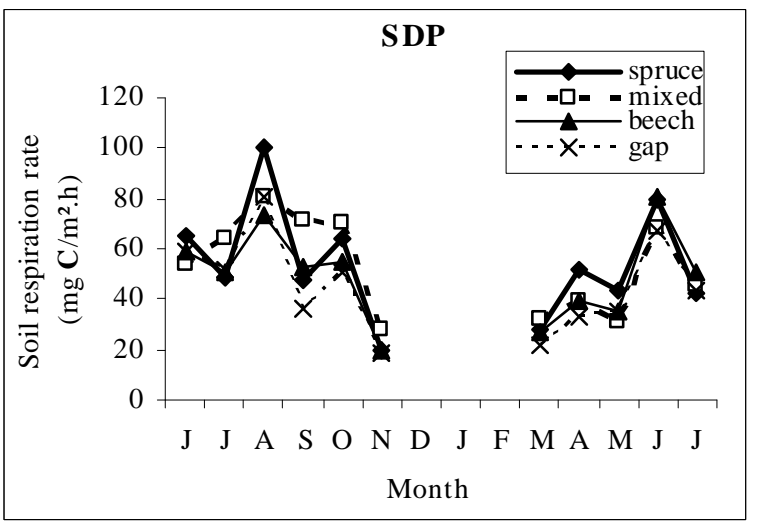

Fig. 22a,b: Temporal variation of mean rate of soil respiration $\left(\mathrm{mg} \mathrm{C} / \mathrm{m}^{2}\right.$.h) in different sub-plots of the a) beech (BDP) and b) spruce (SDP) dominated plot from June 2005 to July 2006.

The monthly variation of soil respiration rates during the period of this study showed no similar trend to the temporal changes of water fluxes via throughfall (Fig. 20 and 22a, b).

As mentioned in the material and method section, it was not possible to measure soil respirations during winter months (December, January and February). It was assumed that the soil respiration during winter was negligible. The Annual soil respirations were 211-395 g C.m $\mathrm{m}^{-2}$.year ${ }^{-1}$ in BDP and 279-339 g C.m ${ }^{-2} \cdot$ year $^{-1}$ in SDP (Tab.15). 
(a)

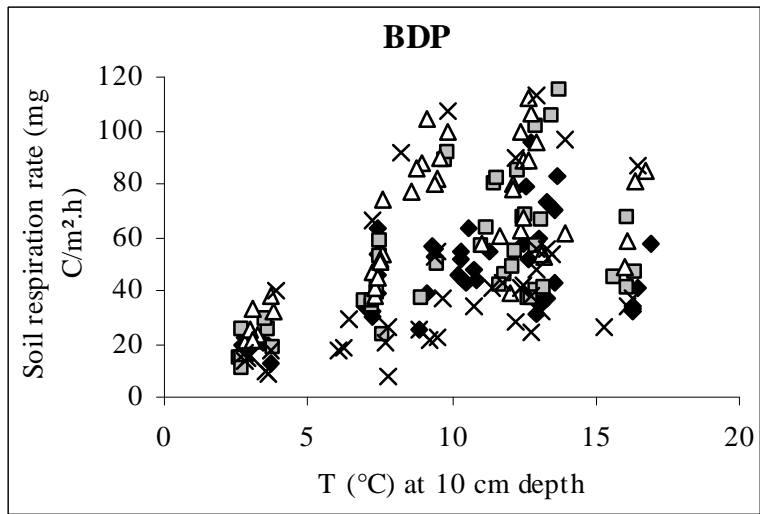

(b)

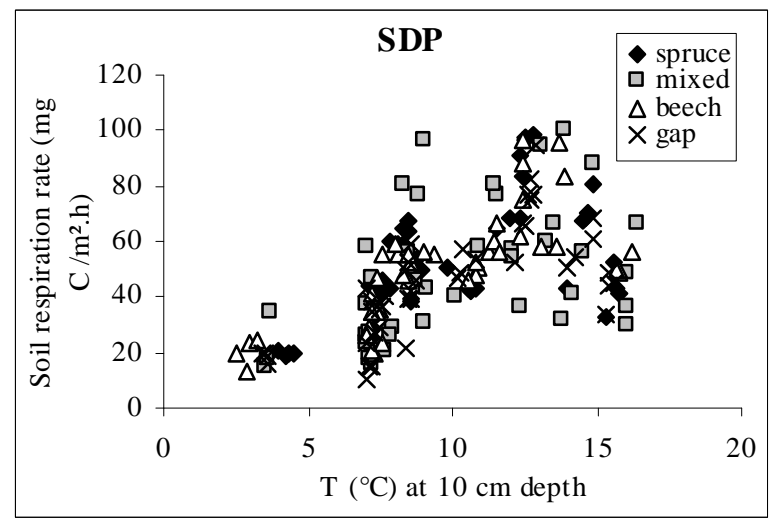

Fig. 23 a,b: Relation between the rate of soil respiration and the soil temperature at 10 $\mathrm{cm}$ depth in the a) beech (BDP) and b) spruce (SDP) dominated plot.

The estimation of the root-associated $\mathrm{CO}_{2}$ production based on a model given by Raich and Nadelhoffer (1989) revealed that the total belowground carbon allocation (TBCA) or root $\mathrm{CO}_{2}$ production were 51-231 g C.m $\mathrm{m}^{-2} \cdot \mathrm{h}^{-1}$ in BDP and $160-234 \mathrm{~g} \mathrm{C} \cdot \mathrm{m}^{-2} \cdot \mathrm{h}^{-1}$ in SDP (Tab. 15). The ratios of $R_{\text {res }} / S_{\text {res }}$ for each sub-plot showed that the contributions of the root respiration to total soil respiration in SDP (57\%-69\%) were more than in BDP (24\%-59\%). The gap subplots in both plots showed the relatively lowest contribution of root in total soil respiration (Tab. 15). 


\section{Discussion}

\subsection{Throughfall}

The results have shown that throughfall fluxes of most of the elements were considerably higher under the canopy of spruce than beech. The total water fluxes, on the other hand, tended to be higher under the beech canopy than under the canopy of spruce in both plots. The differences in total element fluxes between spruce and beech canopy classes cannot, therefore, be caused by differences in water fluxes under the two species, but reflect differences in their canopy properties. Higher filtering capacity of spruce canopy and higher foliage longevity compared with beech have been pointed out as the main reasons for higher element fluxes in throughfall under spruce (Ranger, 2001; and Rothe et al., 2002).

The tendency of higher $\mathrm{pH}$ values under the beech canopy compared with spruce and seasonal variability of $\mathrm{pH}$ values under different canopy classes can be explained by different rates of $\mathrm{H}^{+}$ buffering process in the canopies. The great ability of beech foliage to reduce $\mathrm{H}^{+}$ion concentration in throughfall has been pointed out by Staelen et al. (2006).

Interspecific differences between spruce and beech canopies observed in current study were in agreement with previous comparative studies in pure beech and spruce stands (Nihlgård, 1970; Růžička, 1994; Messenburg et al., 1995; Rothe et al., 2002; Oulehle and Hruška, 2005). Moreover, spruce and beech canopy classes showed the same pattern of differences in two contrasting types of mixture in this investigation. This indicates that canopies of beech and spruce would show the same species-related differences in mixed stands of various beechspruce proportions. Studies of the throughfall under different species growing in mixtures are rare. Based on available knowledge there is no published study on differences in throughfall chemistry under beech and spruce crowns in a mixed forest. Wilpert (personal communications) did not find any significant differences in nutrient concentrations in throughfall under spruce growing in monocultures and in admixture with beech. Rothe and Binkley (2001) suggested that the nutrient inputs with atmospheric deposition would not vary for the same species in monocultures and mixtures.

On the other hand, the influence of the dominating species on the water and element fluxes in gaps, under mixed canopies and also under the canopy of admixed species were also observed 
in this study. As spruce, compared with beech, has higher element fluxes in throughfall and lower amounts of water, this influence can be seen when comparing the fluxes of water and elements for the corresponding canopy classes in the SDP and BDP. Tab.16 shows the SDP/BDP ratios of water and element fluxes via throughfall for different canopy classes. The impact of the dominating species were more pronounced in mixed and gap canopy as the ratios were higher than 1 for all of the elements. The fluxes in pure beech and pure spruce canopy classes in the two plots were relatively similar and for some of the elements the ratios were lower than 1, which might be related to the differences in throughfall water fluxes $(25 \%$ lower in the SDP) and to the possible differences in foliar nutrient status of trees in the two plots. The investigated plots in this study represent two widely contrasting types of beech/spruce mixtures in terms of the proportional contribution of each of the species. In a mixed stand with a more balanced tree composition the differences between the canopies of spruce and beech will be even more similar to the interspecific differences between beech and spruce observed in monocultures.

Tab. 16: The SDP / BDP ratio of water and element fluxes via throughfall for different canopy classes.

\begin{tabular}{lcccc}
\hline & & & & \\
& spruce & mixed & beech & gap \\
\hline Water & 0.7 & 0.8 & 0.9 & 0.9 \\
$\mathrm{H}^{+}$ & 1.6 & 1.6 & 1.5 & 1.2 \\
$\mathrm{Na}^{+}$ & 0.9 & 1.1 & 0.9 & 1.1 \\
$\mathrm{~K}^{+}$ & 0.9 & 1.1 & 0,7 & 1.3 \\
$\mathrm{Ca}^{2+}$ & 1.2 & 1.5 & 1.0 & 1.9 \\
$\mathrm{Mg}^{2+}$ & 1.0 & 1.4 & 0.7 & 1.3 \\
$\mathrm{Mn}^{2+}$ & 1.3 & 1.9 & 0.5 & 1.4 \\
$\mathrm{NH}_{4}{ }^{+}-\mathrm{N}$ & 1.0 & 1.2 & 1.1 & 1.4 \\
$\mathrm{NO}_{3}{ }^{-}-\mathrm{N}$ & 0.8 & 1.3 & 1.1 & 1.4 \\
$\mathrm{SO}_{4}{ }^{2-}-\mathrm{S}$ & 1.2 & 1.6 & 1.0 & 1.5 \\
$\mathrm{Cl}^{-}$ & 0.9 & 1.2 & 1.0 & 1.3 \\
$\mathrm{DOC}$ & 1.2 & 1.5 & 1.1 & 2.1 \\
Norg & 1.0 & 1.2 & 1.2 & 1.5 \\
\hline
\end{tabular}

The spruce canopy with a more circular and symmetric architecture may create more systematic spatial variability in throughfall compared with a beech canopy, which has a more heterogeneous crown structure (Beier et al, 1993; Hansen, 1995; Seiler and Matzner, 1995; Whelan et al, 1998; Zirlewagen and von Wilpert, 2001; Staelen et al., 2006). In this study the throughfall in gap in the BDP showed more similarities with the throughfall of the dominating species even though the gap in the BDP was created by the felling of a single beech tree a few 
years ago while in the SDP the gap has been an open space within the canopy for a long time. At the same time spruce as an admixed species caused more heterogeneity in throughfall samples under different canopy classes than beech in the SDP. This indicates the higher capacity of a spruce tree to influence throughfall patterns in a beech-dominated stand compared to the effect of a beech tree in a spruce-dominated site.

In both plots the water and element fluxes via throughfall under the mixed canopies showed values which were similar or intermediate (particularly for the BDP) between the values for beech and spruce canopies. However, for $\mathrm{K}^{+}$the pattern was substantially different. The annual fluxes of $\mathrm{K}^{+}$under the mixed canopies in both plots were considerably higher than the fluxes under spruce and beech canopies. If it is assumed that the beech and spruce canopy classes were mixed at the ratio of $1: 1$, the simple summation of throughfall input cannot represent the values found in the mixed classes. The high inputs of $\mathrm{K}^{+}$under mixed canopy may be related to the overlapping of spruce and beech canopies in and the interaction between the canopies of the two species. The spruce trees in both plots were taller than the beech trees, so the rainfall water first passed through the spruce canopy, which is characterised by high interception capacity, and then the canopy of beech with its high susceptibility to leaching. The separate calculation of $\mathrm{K}^{+}$ amounts in throughfall depending on the season has shown that the fluxes of $\mathrm{K}^{+}$were higher in mixed canopy categories even in the leafless period. During this period the $\mathrm{pH}$ of throughfall under the spruce canopy in this investigation tended to be lower in the leafless part of the year than the $\mathrm{pH}$ of bulk precipitation, particularly in the SDP plot (Fig. 7). Since potassium is leached more under more acidic condition (Khanna and Ulrich, 1991; Langusch et al, 2003) the higher acidity of water might have promoted the leaching of potassium from beech branches. The calculated amount of leached potassium in the throughfall was highest under the mixed canopies in both plots (Fig.8).

According to the calculations based on Ulrich's model, the canopy leaching was an important source of base cations in the throughfall. In all canopy classes and in both plots more than $50 \%$ of $\mathrm{Ca}^{2+}$, about $60 \%$ of $\mathrm{Mg}^{2+}$ and about $90 \%$ of $\mathrm{K}^{+}$in the throughfall originated from canopy leaching. These findings were in good agreement with the values reported by Nordén (1994) for the throughfall under beech crowns in three mixed deciduous forests in Southern Sweden. His data has showed that, depending on the site conditions, the canopy leaching was the source of $60-70 \%$ of $\mathrm{Ca}, 50-80 \%$ of $\mathrm{Mg}$ and $80-90 \%$ of $\mathrm{K}$ in beech throughfall. Based on 15 case studies in beech and spruce forests in Europe, Rothe et al. (2002) have reported slightly lower values: $37 \%$ for $\mathrm{Ca}, 34 \%$ for $\mathrm{Mg}$ and $80 \%$ for $\mathrm{K}$. 


\subsection{Litterfall}

Rothe and Binkley (2001) have suggested that the higher mobility of beech leaves together with lower mobility of the spruce litter will cause higher total foliar litterfall amounts under spruce canopies, but such a pattern was not found in the current investigation. In this study, the distribution pattern of total foliar litterfall was fairly homogeneous and did not cause any variation in nutrient input among different canopy categories. This might be related to the fact that there were such an extreme case of mixtures in terms of beech-spruce proportions. The distribution of beech litter that has accounted for more than $90 \%$ of total foliar litter in all canopy categories in the BDP was very homogeneous. In the SDP the mobility of beech leaves, which, depending on canopy category, contributed $17-43 \%$ to the total foliar litterfall, was more restricted, possibly due to the effect of surrounding spruce trees. Such a distribution together with small differences in the concentration of most of the elements in beech and spruce foliar litterfall have resulted in similar element fluxes via foliar litterfall among different canopy categories in both plots, with the exception of magnesium. In the case of magnesium the element concentration in leaf litter was considerably higher than in needle litter (Fig. 10). This has caused significantly lower magnesium input under spruce canopies compared with other canopy categories in the SDP. In the BDP, the same tendency could be observed, but the differences were not significant due to more homogeneous distribution of beech leaf litter. The difference in $\mathrm{Mg}^{2+}$ input via litterfall under the spruce canopy was reflected in lower concentration of this element in the soil organic layer under the spruce canopy compared to other canopy classes at the studied plots (Tab. 7). This is in accordance with results reported by Thelin et al. (2002), who have found lower $\mathrm{Mg}^{2+}$ concentration in the upper $(0-10 \mathrm{~cm})$ mineral soil under spruce trees growing with beech in mixtures than under spruce in monoculture stands.

Nutrient concentrations in beech and in spruce foliar litterfall in this study were within the range reported by other authors for foliar litterfall of these species (Matzner, 1988; Pedersen and Bille-Hansen, 1999; Berg and Gerstberger, 2004), with exception of manganese, which was a little higher in this study, particularly in the BDP. The element fluxes via litterfall in all canopy classes in the BDP were always higher than in the corresponding canopy categories in the SDP, mainly due to the higher total amount of foliar litter in this plot (Tab. 7) but also due to a higher nutrient concentration in both needle and leaf litterfall for the case of potassium, calcium and manganese (Fig. 4). 
Although the concentration of elements found in foliar litter will also depend on processes of nutrient resorption and leaching, the higher concentrations of $\mathrm{K}^{+}$and $\mathrm{Ca}^{2+}$ in foliar litterfall in the BDP indicate a positive effect of beech trees on the nutrient availability of these elements in mixed beech-spruce stands. In the case of $\mathrm{Ca}^{2+}$ the ability of beech trees to improve the calcium circulation in spruce stands due to calcium uptake from deeper soil horizons (known as the Ca-pump effect) has previously been suggested (e.g. Berger et al., 2006). With regard to $\mathrm{K}^{+}$, the results of this study correspond to those of Thelin et al. (2002) who have reported substantially higher $\mathrm{K}^{+}$concentrations in current year needles of Norway spruce growing in mixtures with beech compared with spruce monocultures. Calcium concentrations in needles in their study varied from 1.4 to $6.0 \mathrm{mg} / \mathrm{g}$ and showed no significant differences between beech-spruce mixtures and spruce monocultures, but the median concentration was $34 \%$ higher in mixed stands than in pure spruce stands. In contrast, Rothe et al. (2003) who have used a different approach (known as the neighbourhood approach) to investigate the effects of broadleaves on nutrient status of coniferous in various mixed stands have not observed any positive effects.

\subsection{Total nutrient inputs}

The importance of throughfall and litterfall fluxes in total nutrient inputs to the soil surface varies depending on the nature of the elements. Stachurski and Zimka (2002) showed that nearly $80 \%$ of potassium in foliage existed in ionic form, while for $\mathrm{Mg}$ and $\mathrm{Ca}$ the values were much smaller: $40 \%$ and $20 \%$ respectively. As potassium is so highly leachable, throughfall is the main source of $\mathrm{K}^{+}$inputs to the soil surface in forest ecosystems (e.g. Nordén 1994; Duchesne et al., 2001; Langusch et al., 2003). The same role of throughfall in $\mathrm{K}^{+}$inputs to the soil surface was observed in this study. The differences in total potassium inputs among the canopy categories have clearly reflected the differences between them in $\mathrm{K}^{+}$ fluxes via throughfall. The high total inputs of $\mathrm{K}^{+}$under mixed canopies may therefore be caused by higher $\mathrm{K}^{+}$leaching in this canopy category.

In contrast to $\mathrm{K}^{+}$, litterfall was the major source of inputs for $\mathrm{Ca}^{2+}$ in all canopy classes. However, in spruce canopy categories in both plots and in mixed canopy category in the SDP the relative contribution of throughfall to the total $\mathrm{Ca}^{2+}$ fluxes was close to $50 \%$. As the calcium inputs via leaf litterfall were very similar among all canopy categories (Tab. 7) the total inputs of these elements was higher under spruce and mixed canopy categories, reflecting the differences in $\mathrm{Ca}^{2+}$ inputs via throughfall among the canopy categories (Tab. 5). 
The lower magnesium inputs with litterfall in spruce canopy categories compared with beech and mixed canopy classes (especially pronounced in the SDP) was compensated by high $\mathrm{Mg}^{2+}$ fluxes via throughfall.

Even though litterfall may have a homogenising effect on nutrient inputs to the soil surface, as was observed in this study, the total nutrient fluxes under different canopy categories in a mixed beech spruce forest will differ due to spatial patterns of throughfall.

\subsection{Forest floor and mineral soil}

The results of the current study showed that the influence of the forest canopy was mainly limited to the organic layer and the upper 10 to $20 \mathrm{~cm}$ depth of the mineral soil. The differences in soil chemical characteristics among sub-plots in the lower mineral soil layers (20-40 cm) were small and not significant. In accordance with this finding, Rothe et al. (2002a) believed that tree composition may clearly alter top soil properties.

In the present study, the variations in soil chemistry of the forest floor and top mineral soil were mainly observed with respect to the $\mathrm{pH}$ and the concentrations of total carbon, potassium and calcium. The observed differences in the soil chemistry between sub-plots may suggest that the detectable differences in soil chemical characteristics mainly resulted from differences among canopy categories. Augusto et al. (2002) reviewed the impact of tree species on soil productivity in temperate forest. They concluded that the intensively impacts of tree canopies on the forest floor and uppermost mineral soil properties may be caused by enhancing the fluxes of water and elements. In the present investigation, water and element inputs (especially via throughfall) showed significantly different fluxes under different canopy classes in both plots (BDP and SDP; see Tab. 5).

In this study, a significant influence of canopy composition on the $\mathrm{pH}\left(\mathrm{CaCl}_{2}\right)$ of the $\mathrm{O}_{\mathrm{H}}$ layer was observed in the spruce dominated plot (SDP). Lower $\mathrm{pH}$ values of the $\mathrm{O}_{\mathrm{H}}$ layer under the spruce canopy class was found compared to the gap in the SDP plot. This can be explained by the acidity of throughfall. The $\mathrm{pH}$ of throughfall in the gap and beech sub-plots tended to be lower compared to the spruce sub-plot (Tab. 5). Roth et al. (2002a) also claimed that the acidity of throughfall has a strong impact on the $\mathrm{pH}$ of organic and mineral soil layers. At the same time, production of high molecular weight organic matter with slow decomposition rate 
in the litter layer (Binkley and Valentine, 1991; Hagen-Thorn et al., 2004) may cause acidic condition under the crown of spruce trees.

According to Rothe (1997) the $\mathrm{pH}$ of the organic and mineral soil in spruce stands showed lower values compared with beech stands. However, in the current investigation, the $\mathrm{pH}$ of the $\mathrm{O}_{\mathrm{H}}$ layer in the beech sub-plots showed no significant differences compared with the spruce sub-plots. This can be explained by the impact of stemflow beneath the canopy of beech trees. Stemflow can change the soil chemistry of the proximal area (area next to the stem base) under the crown of trees in beech monocultures (Koch and Matzner, 1993; Matschonat and Falkengren-Grerup, 2000). In addition, the admixture of spruce and beech trees may decrease the $\mathrm{pH}$ of beech stemflow (Levia Jr. and Frost 2003). In the SDP, the area of beech sub-plot was limited under the canopies of two beech trees surrounded by spruce trees. Hence, the influence of stemflow can decrease the $\mathrm{pH}$ of soil in the zone around the base of stem under the beech canopy. Consequently, no significant difference was observed in the $\mathrm{pH}$ of organic layer between the spruce and beech subplots.

The thickness of litter layers under different canopy classes in both plots showed no significant differences. The homogenising effect of beech foliar litterfall in the small scale of investigated plots may presumably cause the similar thickness of litter layers in different subplots. However, the mass of $\mathrm{O}_{\mathrm{L}+\mathrm{F}}$ layers under the spruce canopy was greater than in the beech and gap sub-plots. According to Binkley and Valentine (1991), Rothe et al, (2002a) and Berger et al. (2006), the forest floor of the spruce stands are characterized by relatively thicker and contains more organic matter compare to the forest floor of beech stands. Lower mobility (Rothe and Binkley, 2001) and slower decomposition rates of spruce litter (Binkley and Valentine, 1991), compared with beech litter may result in the build up of the forest floor with high bulk density in spruce stands. Less favourable micro-environmental conditions for microbial activity in spruce stands compared with beech stands have also reported by Sarilyildiz et al. (2005) and Albers et al. (2004). Rothe et al. (2002b) claimed that the properties of the forest floor of mixed spruce-beech stands are more similar to spruce stands than beech stands. In the current study, , presumably due to more resistance organic matter to decay, no obvious difference was found in dry weight of the $\mathrm{O}_{\mathrm{H}}$ layer between the spruce and beech sub-plots. 
Variations in $\mathrm{C}$ and other nutrient storages between the spruce and beech sub-plots were in some cases comparable with the finding of earlier investigations in pure and mixed beech spruce stands (Berger et al., 2002 and the references therein). Higher stocks of carbon in the forest floor were found in the spruce sub-plots compared with the other subplots in both plots. This may result from the higher rate of litter accumulation under spruce canopy (Ulrich et al., 1971). Mean annual fluxes of litterfall did not vary among sub-plots in SDP as well as BDP (Tab. 6). The higher storage of $\mathrm{C}$ in the forest floor of the spruce sub-plot, compare to the mixed subplot in BDP and compare to the beech and gap subplots in SDP may indicate the differences in created micro-sites under different canopy classes. The litter quality and microenvironmental factors under different canopy classes can control the microbial activity differently (Nordén, 1994). Moreover, in the spruce sub-plot, higher interception deposition compared to the beech sub-plot could have led to higher nutrient inputs (inorganic nitrogen ions and base cations) via throughfall. Those nutrients are readily available for micro organisms and reduced the decay rate of organic matter (Dignac et al., 2002). At the same time, the incorporation of superficial roots of spruce trees in the organic and top $10 \mathrm{~cm}$ of mineral soil (particularly in the SDP) may be another reason for higher carbon concentration in the spruce sub-plots (Fig. 12a, b). According to Majdi and Persson (1993), the importance of fine roots in spruce stands as the sources of organic mater in organic and top mineral soil is approximately the same as litterfall.

In both plots, $\mathrm{N}$ concentrations showed no significant differences in the $\mathrm{O}_{\mathrm{L}+\mathrm{F}}$ and $\mathrm{O}_{\mathrm{H}}$ layers among different sub-plots. However, the whole organic layers under the spruce canopies showed significantly higher $\mathrm{N}$ storages compared to the other sub-plots. This might be a result of relatively lower rates of organic matter decomposition which is associated with $\mathrm{N}$ mineralization under the crown of spruce (Alber et al., 2004). The higher quality of litter and higher rates of decomposition in beech stands (Sariyildiz et al., 2005) can explain the lower $\mathrm{C} / \mathrm{N}$ ratios in the beech dominated plot. Rothe (1997) also found higher $\mathrm{C} / \mathrm{N}$ ratios in the organic and top mineral soil of spruce stand compared with beech stand.

Dry weight of organic matter also determines the storages of other elements in the forest floor of different sub-plots in this study. In the beech dominated plot, presumably as the effect of stemflow, the beech subplots showed significantly higher concentration of $\mathrm{K}^{+}$and $\mathrm{Al}^{3+}$ in the $\mathrm{O}_{\mathrm{L}+\mathrm{F}}$ layer, compared with the gap and spruce sub-plots. Whereas the only difference in the 
storages of potassium and aluminium in the forest floor was observed in the gap sub-plot, compared with the beech and spruce sub-plots.

Based on Tab. 5, the mixed subplots of BDP and SDP received considerably higher amounts of $\mathrm{K}^{+}$via throughfall compared to other subplots. Thus, the higher potassium concentrations in the $20 \mathrm{~cm}$ depths of the mineral soils at both plots are probably caused by the higher inputs of potassium via throughfall under the mixed canopy classes.

The organic acids produced in the forest floor or acid originated directly from throughfall under different canopy may change the content of exchangeable cations and base saturation in different soil layers (Jönsson et al., 2003). In the present study, differences in base saturation among subplots were mainly due to changes in calcium saturation. This was most pronounced in the gap sub-plot at the BDP and in the mixed sub-plot at the SDP (Tab.11). In the upper mineral horizon in both plots the high concentration and storage of $\mathrm{Ca}$ was probably caused by Ca- pump effect by deep rooting system of beech trees. Berger et al. (2006) suggested that the acidifying effect of spruce accelerate the mobilization $\mathrm{Ca}$ in the upper mineral soil of mixed spruce-beech stand.

The higher concentration of $\mathrm{Ca}$ in 0-10 $\mathrm{cm}$ mineral soil depth in the gap sub-plot of the BDP may be related to higher rates of litter decomposition. The gap in BDP has been originated by felling a beech tree some years ago. Gap formation might induce mineralization process (Prescott, 2000). Another reason for enhanced exchangeable Ca concentration might be high density of ground vegetation in gap sub-plot. Enhanced of $\mathrm{Mg}^{+}$concentrations in the upper 10 $\mathrm{cm}$ depth in the mixed sub-plots in both plots may be caused by higher nutrient inputs via foliar litterfall under the mixed canopy class. This is in accordance with results reported by Thelin et al. (2002), who have also found higher $\mathrm{Mg}$ concentration, in the upper $(0-10 \mathrm{~cm})$ mineral soil under spruce trees growing with beech in mixtures than under spruce in monoculture stands.

Aluminium concentrations under beech canopy classes (sub-plots) tended to be higher compared to other subplots (particularly in BDP). This can be as a function of stemflow to change the soil chemistry under the canopy of beech trees. As it has been discussed in this section, stemflow can reduce the $\mathrm{pH}$ of soil under the canopy of beech. The higher $\mathrm{H}^{+}$ concentration leads to the greater aluminium concentration (Koch and Matzner, 1993). 


\subsection{Soil solution}

The spatial heterogeneity of the soil solution $\mathrm{pH}$ in the spruce and beech sub-plots in the present study was strongly related to the pattern of water fluxes via throughfall. As given in Tab. 5, in both plots, BDP and SDP, the fluxes of water via throughfall were higher under the beech canopy classes, compared with the spruce canopy classes. Augusto and Ranger (2001) also claimed that greater throughfall water fluxes can be statistically linked to higher $\mathrm{pH}$ values of the soil solution. This behaviour can be explained by the higher interception loss of rainfall by the spruce canopy compare to the beech canopy (Toba and Ohta, 2005; Christiansen, 2006).

The $\mathrm{pH}$ of the soil solution at $10 \mathrm{~cm}$ depth in these sub-plots showed intermediate values between the spruce and beech sub-plots. The flux of water in the mixed and gap sub-plots tended to be higher compared with the beech sub-plot. This may suggest that the water input via throughfall was not the only factor which controls the spatial pattern of soil solution. On the plot scale the distribution of roots and the microbial activity can significantly alter the chemistry of soil water (Manderscheid and Matzner, 1995). Furthermore, the given mixed and gap canopy classes of this study exhibit a very complex structure. The formation of the mixed canopy classes was due to the overlapping of the canopy of spruce and beech. The development of spruce canopy was limited in the proximal area around spruce trunk. In the mixed canopy class the proportion of spruce canopy was more than beech canopy. Therefore, the influence of the spruce canopies on the soil and soil solution chemistry in the mixed subplots were higher than the influence of beech canopies. In the gap subplots, the higher measured decay rate associated with a higher mineralization rate after gap formation in the beech dominated plot (BDP) and the influence of surrounding canopy in the spruce dominated plot (SDP) may lead to lower $\mathrm{pH}$ in the soil solution.

High concentrations of potassium in the soil solution of the spruce sub-plot in BDP may be related to the higher leaching of this cation from the spruce canopy, compared with the beech and gap sub-plots. It might be also related to the lower amount of throughfall and incorporating water in the soil profile of the spruce sub-plot.

The molar ratios of base cations to aluminium (BC/Al) in the soil solution below 1.0 can cause physiological stress to fine roots (Ulrich, 1989). In the mixed and gap sub-plots, lower 
concentrations of base cations in the soil solution, due to less interception deposition and the tendency of higher concentration of $\mathrm{Al}$ led to lower ratio of $\mathrm{BC} / \mathrm{Al}$.

At SDP, higher mean concentrations of $\mathrm{K}^{+}$and $\mathrm{Ca}^{2+}$ in the soil solution of the mixed sub-plot, compared with the beech and gap sub-plots may caused by higher flux of these elements via litterfall and throughfall (Tab.13). This may also be related to the mean concentration of exchangeable potassium and calcium. The concentration of exchangeable $\mathrm{K}^{+}$and $\mathrm{Ca}^{2+}$ at 10 $\mathrm{cm}$ depth of mineral soil tended to be higher in the mixed sub-plot compared to the other subplots. High concentration of $\mathrm{Ca}^{2+}$ in the seepage water (at $100 \mathrm{~cm}$ soil depth) under spruce and mixed stands may be a result of Ca mobilization by acidifying effect of spruce litter (Berger et al., 2006).

The higher concentration of $\mathrm{SO}_{4}{ }^{2-}$ in the soil solution under the spruce and mixed canopy classes may be due to atmospheric deposition. In the present study, the fluxes of sulphate under the spruce and mixed canopy classes were significantly higher compared with the beech and gap subplots. According to Augusto and Ranger (2001), and Oulehle and Hruška (2005) high concentrations of sulphate in spruce stands can be caused by the high input of sulphate via throughfall. Moreover, acidified soils can act as a source of sulphate (Wilpert and Mies, 1995; Rothe et al., 2002b).

Properties of different sub-plots can be quantified by the hydrochemical input/output budget. In order to estimate a hydrological input-output balance, the flux of seepage water below the rooting zone (at $100 \mathrm{~cm}$ depth of soil) is necessary. However, water modelling was not the focus of this study.

For the vegetation period of 2001, Cheussom (2004) modelled the fluxes of seepage water under different canopy classes in the given mixed spruce and beech plots at Solling. However, due to the lack of main seepage water output in winter season, his estimation is not sufficient to calculate annual water output flux. Hence, other published data from a neighbouring pure beech (plot B1; Brumme, in press), a spruce stand (control plot of the Solling Roof Project; Xu et al., 1998), and a gap (Bartsch, 2000) were applied to estimate water output fluxes. 
To gain seepage water fluxes for each sub-plot in this study, the annual average of long term water output flux were used to calculate a factor between throughfall and seepage water. This factor was applied to estimate the amount of annual seepage water. It means that the flux of seepage water of the given sub-plots was a rough estimation based on measured annual throughfall water flux in each sub-plot multiply by the calculated factor (ratio between long term mean of input and output water fluxes from the available data). However, mean values between the spruce and beech sub-plots were used as the factor to calculate seepage water fluxes for the mixed sub-plots.

Results of the estimated water and major element output fluxes for the investigated plots are given in Tab.17. The output fluxes were calculated by the multiplication of element concentrations by the estimated fluxes of seepage water at $100 \mathrm{~cm}$ of soil depth.

The estimated water and ion fluxes at $100 \mathrm{~cm}$ soil depth showed differences among different sub-plots at both, BDP and SDP. The amounts of nitrate and calcium in seepage water below the rooting zone of BDP and SDP showed about two folds greater fluxes in the gap sub-plots, compared with the other sub-plots. This may be attributed to the higher mineralization rate (Wilpert and Mies, 1995; Wilpert et al., 2000; Prescott, 2002; Ritter and Vesterdal; 2006), lower root densities (Brumme, 1995) and greater flux of seepage water in the gap sub-plots, compared with the other sub-plots. Bartsch (2000) also found greater nitrate and calcium output in a gap, compared with the adjacent mature stands in Solling forest.

Tab. 17: Mean annual water $(\mathrm{mm})$ and element $\left(\mathrm{g} / \mathrm{m}^{-2}\right.$ year $)$ fluxes at $100 \mathrm{~cm}$ soil depth in different sub-plots of the beech (BDP) and spruce (SDP) dominated plot.

\begin{tabular}{lcccccccc}
\hline & $\begin{array}{l}\text { BDP } \\
\text { SPRUCE }\end{array}$ & MIXED & BEECH & GAP & $\begin{array}{l}\text { SDP } \\
\text { SPRUCE }\end{array}$ & MIXED & BEECH & GAP \\
\hline & & & & & & & & \\
$\mathrm{S.W}^{*}$ & 319 & 446 & 484 & 596 & 238 & 378 & 442 & 518 \\
$\mathrm{~K}^{+}$ & 0.7 & 0.4 & 0.3 & 0.4 & 0.6 & 0.7 & 0.3 & 0.4 \\
$\mathrm{Ca}^{2+}$ & 0.7 & 0.6 & 0.6 & 1.8 & 0.8 & 1.3 & 0.6 & 1.6 \\
$\mathrm{Mg}^{2+}$ & 0.6 & 0.5 & 0.5 & 0.6 & 0.6 & 0.5 & 0.3 & 0.5 \\
$\mathrm{SO}_{4}{ }^{2-}$ & 1.9 & 2.2 & 1.8 & 1.9 & 2.0 & 2.3 & 1.5 & 2.2 \\
$\mathrm{NO}_{3}^{-}$ & 0.8 & 0.5 & 0.5 & 1.8 & 0.7 & 0.3 & 0.1 & 1.5 \\
\hline *S.W.: Calculated seepage water. & & & & & & &
\end{tabular}

The hydrochemical input-output budget (Fig. 20) showed a net output of sulphate for all subplots. In agreement with other European case studies, this indicates that acidified forest soils 
in Solling still act as a source of sulphate output (Wilpert and Mies, 1995; Rothe et al., 2002a).

In this study, due to high standard deviation, no significant differences were detected in the concentration of $\mathrm{NO}_{3}{ }^{-}$in the seepage water (at $100 \mathrm{~cm}$ depth) between the spruce and beech sub-plots. However, in both plots, the spruce sub-plots showed higher tendency of nitrate concentration, compared with the beech sub-plots. Therefore, nitrate output in the spruce subplots were slightly higher than in the beech sub-plots.

For the gap sub-plots at BDP and SDP a net nitrate and calcium output was calculated. According to Rothe et al. (2002a), nitrate leaching may be influenced by the $\mathrm{N}$ input, litter distribution, decomposition and mineralization processes. The fluxes of nitrate via throughfall in the gap sub-plots in the present study were significantly lower compared with the spruce and mixed sub-plots and similar to the beech sub-plots (Tab. 5). High rates of decomposition, transformation of ammonium input to nitrate (Wilpert and Mies, 1995; Prescott, 2002) and low root densities (Brumme, 1995) to take up available $\mathrm{N}$ may explain net leaching of nitrate from the gap subplots. This means that the forest floor and the mineral soil in the gap subplots are not able to immobilize inorganic nitrogen. According to the concept of "mobile anions", the out put fluxes of nitrate and sulphate are associated by the leaching of equivalent amounts of cations (Reuss and Johnson, 1986). Hence, the nutritional status of the sub-plots is strongly related to the concentration of those mobile anions in the seepage water. 
(a)
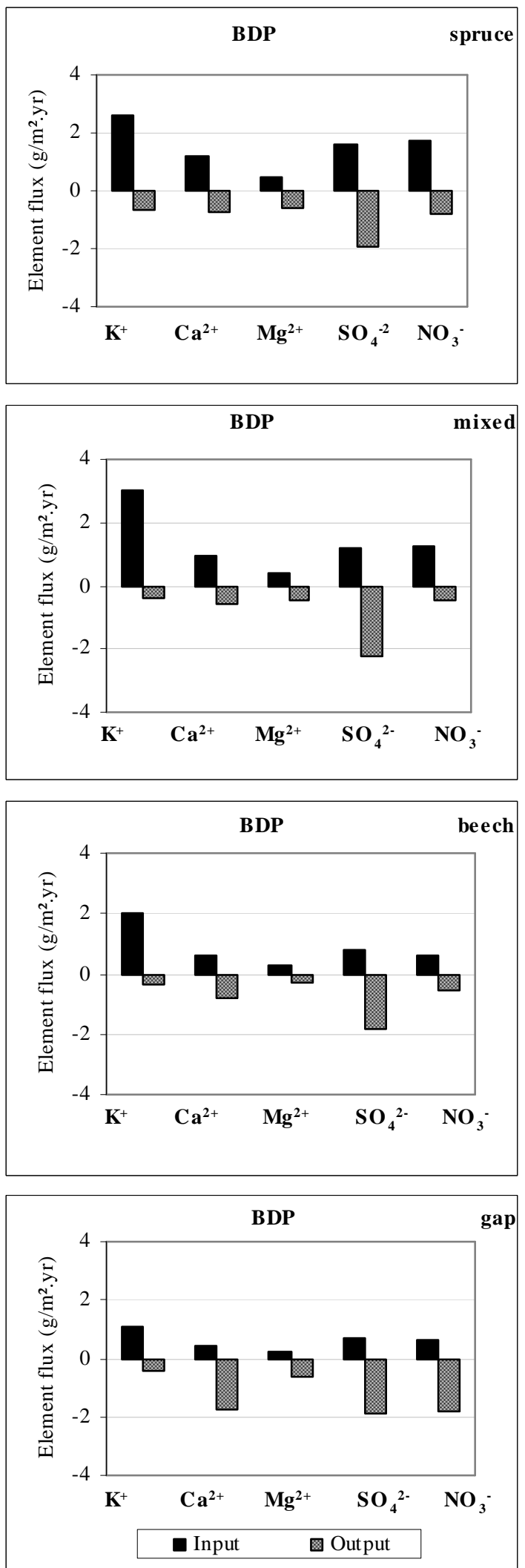

(b)
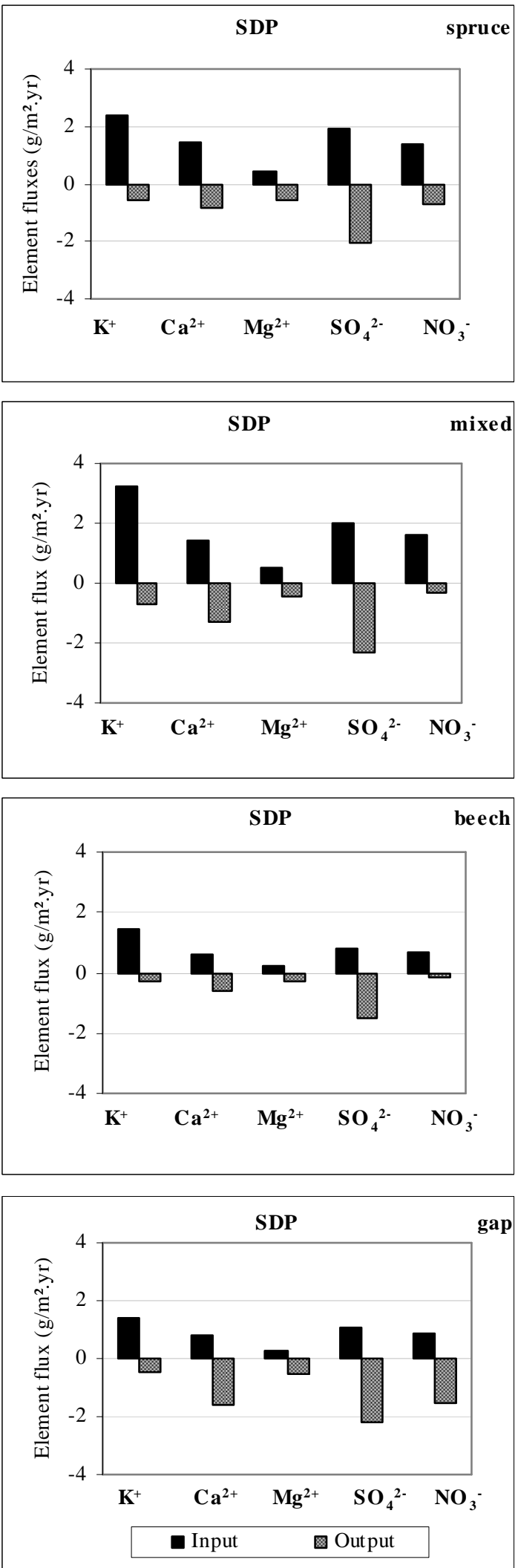

Fig. 24a,b: Annual hydrochemical budgets (input = fluxes via throughfall, output $=$ fluxes of seepage water at $100 \mathrm{~cm}$ depth of the mineral soil) under different canopy classes in the (a) beech (BDP) and (b) spruce (SDP) dominated plot for the period of May 2005 to April 2006. 


\subsection{Litter decomposition and nitrogen turnover}

For a long time the litterbag technique is known as a common method to estimate the decay rate of litter material in forest ecosystems (Berg and Tamm, 1991). It was hypothesised however, that micro-environmental conditions under different canopy classes in a mixed stand may control major part of decomposition processes and nitrogen turnover. Hence, in order to investigate the impact of canopy composition on litter decay rates, the litterbags were filled with a standard needle litter material. The application of the single litter under all canopy classes may reveal one aspect of decomposition process. However, in reality the mixture of litter with different composition under different canopy classes might have a very strong influence on decay rates (Gartner and Cardon, 2004).

The results of the applied litterbag experiment revealed that about half of litter material decayed after about 420 days of the incubation period. This means, in the absent of mechanical breakdown by large animal, a substantial degradation of the litter material occurred. This finding is in agreement with results of other studies with a similar application technique (Staff, 1988; Berg, 2000; Alber et al., 2004).

The beech and gap sub-plots in the beech dominated plot (BDP) showed significantly higher mass losses of decomposing needle, compared with the spruce sub-plot. This can support the idea that the micro-environmental condition in the forest floor under the canopy of beech is more favourable for the decomposer community. This is in agreement with the finding of earlier comparative studies between pure beech and pure spruce stands (Alber et al., 2004; Sariyiliz et al., 2005). Prescott (2002) reported higher decomposition and mineralization rates of litter in the gap centre compare to a neighbouring mature stand. Furthermore, the rate of litter decomposition in the gap may be influenced by lower water loss via transpiration and interception from the gap and more direct radiation of sun light reaching the forest floor. This might be caused by higher soil moisture and temperature in the gap compare to other parts of the forest ecosystem which finally can lead to higher rates of mass loss (Bjørnlund and Christensen, 2005). At the same time, in comparison to other sub-plots, the litterbags in the gap sub-plots were exposed to the greater amounts of water via throughfall. This may have led to a direct and enhanced leaching of decomposed and soluble compounds of the litter. Heim and Frey (2004) also claimed that the abiotic leaching of soluble substances can influence litter decomposition rate in the early stage after litterfall in temperate forest. 
Differences in the remaining mass and decomposition rates between the beech and spruce sub-plots were observed in the last two months of the incubation period (after 12 months) in the beech dominated plot (BDP). This revealed that the influence of different canopy classes on decay rates seems to start only in the later stage of decomposition. This is in agreement with the findings of Alber et al. (2004) and Sariyiliz et al. (2005). It was found that found that significant differences in the decay rates of spruce needles under pure and mixed sprucebeech stands began only one year after the start of the litterbag incubation. According to Berg and Staff (1980) the nutrient level of the litter material (litter quality) determines the rate of mass loss during the first year of decomposition. Since in the present experiment, all litterbags were filled with identical litter material, the impact of litter quality in all sub-plots was the same. Hence, no significant differences in the decay rates were found among different subplots in the early stage of decomposition.

Two stages were observed in the decomposition process during the period of the applied experiment. In the first stage, the rate of decomposition was higher. This observation is in accordance with previous studies (Berg, 1986; Berg, 2000; Alber et al., 2004). It was stated, that the decomposition rates in the first few months are related to the concentration of watersoluble nutrients while in the following stage, the influence of recalcitrant substrates (lignin) are more pronounced.

The accumulation of nitrogen in the early stage of the decomposition in most sub-plots of this study was in agreement with the findings of previous litterbag experiments (Berg and Staaf, 1980; Staaf, 1988; Berg, 2000; Alber et al., 2004). In accordance with Berg and Ekbohm (1983), nitrogen in the current investigation also showed a fluctuated temporal variation. The initially leaching phase is followed by an absolute increase (net immobilisation) and a subsequent net release (net mineralisation). The relatively longer net leaching phase of total $\mathrm{N}$ in the initial stage of decomposition under the spruce canopy class in the BDP compared to the other sub-plots may be related to the influence of high acidity of throughfall input in the spruce sub-plot.

Simultaneous release and incorporation of nitrogen from litterbags has been stated previously as the main crucial process to describe $\mathrm{N}$ dynamics in litterbag experiments (Berg, 1988; Gebauer et al., 2000). Mechanisms by which this transfer may occur are not clearly understood yet but $\mathrm{N}$ deposition via throughfall, $\mathrm{N}$ input through soil fauna are known as the 
major sources for incorporating N. Possible pass ways of $\mathrm{N}$ release are leaching and litter degradation (Berg, 1988). However, ${ }^{15} \mathrm{~N}$ enriched litter material might be applied to separate the incorporated and released $\mathrm{N}$ in decomposing litter material (Gebauer et al., 2000). It was assumed that the changes in ${ }^{15} \mathrm{~N}$ concentrations during the decomposition period in this study were negligible. Therefore any change in excess of ${ }^{15} \mathrm{~N}$ (the term "excess" is described in further details in the material and method section) resulted from the change in $\mathrm{N}$ concentration. The calculation of $\mathrm{N}$ incorporation as a percentage of initial nitrogen by excess of ${ }^{15} \mathrm{~N}$ in this study revealed that the canopy composition had no significant effect on $\mathrm{N}$ incorporation into incubated litterbags under different canopy classes in both plots.

It was hypothesis that the significant spatial variability of inorganic $\mathrm{N}$ input via throughfall can change the decay rates under different canopy classes. In this study, the spruce sub-plots showed significantly higher annual fluxes of inorganic $\mathrm{N}$ via throughfall, compared with the beech sub-plots (Tab. 5). However, the results of this litter bag experiment provided no evidence that greater $\mathrm{N}$ availability in the spruce sub-plots lead to faster litter decomposition, compared with the beech sub-plots. In contrast, high $\mathrm{N}$ availability in the spruce sub-plot may suppress decomposition process. This is in agreement with the findings of Fogg (1988). Presccot (1995) also found no relationship between mass loss of decomposing jack pine needles and the availability of exogenous N. On the other hand, litter quality may determine the influence of external $\mathrm{N}$ on decay rate (Knorr et al., 2005). This means that high level of external $\mathrm{N}$ can not accelerate the mass loss of low quality litter (Berg, 1988; Dijkstra et al., 2004). Spruce needle litter with relatively high concentrations of lignin (Berg and Staaf, 1980; Alber et al., 2004) was applied as litter material in the present study. Therefore, higher external $\mathrm{N}$ via throughfall in the spruce sub-plot could not stimulate the decay rate of needles compared with the beech and gap sub-plots. Alber et al. (2004) claimed that the retarding condition under the spruce canopy may reduce the decomposition rates of spruce litter. Hence, the high accumulation rate of organic matter takes place under the spruce canopy. In contrast, the condition under the beech canopy is more favourable for decomposition and may accelerate litter mass loss.

\subsection{Soil respiration}

The typical range of $\mathrm{CO}_{2}$ efflux in this investigation was comparable with the finding of a previous study which was done in pure and mixed spruce and beech stands at the Solling forest (Borken and Beese, 2005). 
The correlation between soil respiration and soil temperature in both plots is in general agreement with results of earlier studies in beech and spruce stands (Subke et al., 2003; Epron et al., 2004). The positive relationship between $\mathrm{CO}_{2}$ efflux and top soil temperature suggested that approximately half of the $\mathrm{CO}_{2}$ originated from metabolic activity in the upper most soil layers.

Soil water content can explain a large part of the soil respiration variance in deciduous forest (Anderson et al., 2005). The influence of spatial variability of soil moisture was more pronounce in BDP compared with SDP. This may be explained by the continued canopy cover of spruce trees in the spruce dominated plot (SDP) which prevent considerable temporal changes of soil moisture content.

The findings of this study revealed that the canopy composition influence annual soil respiration. In the beech dominated plot (BDP), the beech sub-plot showed significantly higher soil respiration, compared with the gap sub-plot. Brumme (1995) also expressed 40\% lower soil respiration at the centre of the gap in a mature beech stand compared with the surrounding area under the canopy of beech.

$\mathrm{CO}_{2}$ release from the forest soil originates from two different sources, decomposition of organic matter and respiration of living roots. In this study, the litter bag experiment showed no significant differences in the rate of litter decomposition between the beech and gap subplots in BDP. Therefore, lower rate of soil respiration may be attributed to the root respiration. It was not possible to measure live root respiration in this study. Hence, a model given by Raich and Nadelhofer (1988) was used to calculate the root-associated $\mathrm{CO}_{2}$ production or total belowground carbon allocation (TBCA). In this model, it is assumed that the amount of annual litterfall equals the amount of decomposition of aboveground litter. The comparison of calculated amounts of TBCA between different sub-plots revealed that the root activity in the gap sub-plot might be lower, compared with the beech sub-plot (Tab. 15). The relative contribution of root respiration to total soil respiration in the gap sub-plot was $24 \%$ whereas it was $59 \%$ in the beech sub-plot. At the same time, the biotic and abiotic parameters under the beech canopy may create more desirable condition for microbial activity and consequently higher soil respiration rate. 
The relative contribution of root-associated $\mathrm{CO}_{2}$ production to total soil respiration in the given study was within the ranges reported by other investigations (Raich and Nadelhoffer, 1989; Borken and Beese, 2005; Andersen et al., 2005). In current study the rates of soil respiration and the fluxes of carbon via foliar litterfall were measured only in a 15 months period. Hence, temporal variation of root-associated $\mathrm{CO}_{2}$ production could not be shown because the estimation of TBCA is based on annual measurements and needed more than 2 years period.

At the beech dominated plot (BDP), the annual soil respiration in the spruce sub-plot tended to be lower compare with the beech sub-plot. This can be explained by the greater storage of carbon in the forest floor of the spruce sub-plot. In BDP, C storage in organic horizons under the spruce canopy tended to be higher than in the beech sub-plot. Differences in carbon storage in organic layers may be related to lower rates of litter decomposition under the canopy of spruce which leads to lower rates of soil respiration. This is in accordance with findings of earlier studies in pure and mixed spruce and beech stands (Borken et al., 2002; Borken and Beese, 2005; Elberling and Ladegaard-Pedersen, 2005). Tewary et al. (1982) also found a significantly inverse relationship between carbon storage in the soil and soil respiration in a mixed oak-coniferous forest. In addition an external $\mathrm{N}$ via throughfall under the spruce canopy can suppress $\mathrm{CO}_{2}$ formation (Berg and Matzner, 1997).

At the spruce dominated plot (SDP), despite the significantly higher storage of $\mathrm{C}$ in the spruce sub-plot, compared with the beech and gap sub-plots, annual soil respiration showed no significant difference. The presence of superficial spruce roots in the forest floor and the top mineral soil layer as well as a strong layer of ground vegetation in SDP may mask the differences in soil respiration among different subplots. The greater contribution of root $\mathrm{CO}_{2}$ release to total soil respiration $\left(\mathrm{R}_{\text {res }} / \mathrm{S}_{\text {res }}\right.$ ratios) in the spruce dominated plot (SDP), compared with the beech dominated plot (BDP) may support this idea. According to Raich and Tufekcioglu (2000), in temperate zone, the contribution of root respiration to total soil respiration under broad-leaved stands is relatively lower than under the coniferous stands. 


\section{Conclusions}

The canopy composition in a mixed spruce and beech stand has a great impact on the heterogeneity in element and water fluxes via throughfall. The differences in throughfall water fluxes and chemistry under the canopies of beech and spruce in the two contrasting cases of admixtures were in agreement with previously reported differences between these species grown in monocultures. This result suggested that crowns of individual tree species may show the same behaviour for throughfall nutrient inputs in different kinds of sprucebeech mixed stands. The chemistry of throughfall in gaps and under mixed canopy categories will obviously reflect the differences between beech and spruce canopies but will not necessarily represent a simple average of the throughfall characteristics of the two species, as was clearly demonstrated for the case of $\mathrm{K}^{+}$in the current study. The significantly higher $\mathrm{K}^{+}$ fluxes under the mixed canopies might have resulted from an enhancing effect of spruce throughfall on $\mathrm{K}^{+}$leaching from beech. However, further investigations with sample collection at different canopy heights are needed to monitor the gradual changes in throughfall chemistry within the mixed canopies and to clarify the interaction mechanisms between beech and spruce.

Differences in the soil chemistry under different canopy classes were mainly observed in the forest floor and top mineral soil layers. Despite the homogenising effect of nutrient input via litterfall, different micro-climatic conditions may cause the differences in the storages of carbon and nutrients under different canopy classes. The condition under the canopies of beech and spruce trees are driven by species-specific properties of the canopies and are quite independent of the degree of admixture. This was clearly observed with respect to $\mathrm{pH}$ values, mass of organic matter and concentration and storage of carbon in the forest floor.

The chemical properties of the soil and soil solution in the mixed sub-plots are mainly influenced by the spruce canopy. While in the gap sub-plots, the origin of a gap (felling of a single tree or long lasting open space among the canopy of niegbohring trees) and the ambient dominat tree species obviously determine the chemistry of the soil and soil solution.

It should be noted however, that the given reasons for the observed differences in the soil and soil solution properties under different canopy classes can not be defined with absolute certainty. In this study, canopy composition was applied as the factor to separate different 
sub-plots. The behaviour of spruce and beech trees in their monocultures was mainly used to explain and discuss the significant differences between different sub-plots. Nevertheless, the species specific characteristics are more complex when two species are growing in a mixed stand. The complexity can lead to several uncertainties in the interactions between the canopy and soil compartment particularly in the gap and mixed situations, which are not well understood yet. Hence, it is not possible to discuss about all of observed differences among different sub-plots in this investigation. Fine root as an important source of soil chemical variability exhibit a complex distribution in the forest floor and the mineral soil layers under a mixed spruce-beech stand. Information about fine root biomass and associated nutrients can help to better interpretation the observed differences in biogeochemical properties between different sub-plots.

The impact of an individual spruce tree in a beech-dominated site induced higher degrees of spatial heterogeneity with respect to nutrient inputs, litter decomposition and total soil respiration compared to individual beech trees in a spruce-dominated site. This may suggest that the influence of a small proportion of spruce trees in a dominated beech stand will cause greater biodiversity of soil micro-organisms and higher carbon sequestration compare to a beech monoculture. In contrast, a small proportion of beech trees in a spruce stand are not able to create strong spatial heterogeneity in carbon and nutrient cycling. 


\section{References}

Aber J.D., Mellillo J.M. and Mc-Clagherty C.A., 1990. Predicting long-term patterns of massloss, nitrogen dynamics, and soil organic matter formation from initial fine litter chemistry in temperate forest ecosystems. Canadian Journal of Botany. 68(10): 2201-2208.

Alber D., Migge S., Schaefer M. and Scheu S., 2004. Decomposition of beech leaves (Fagus sylvatica) and spruuce needles (Picea abies) in pure and mixed stands of beech ad spruce. Soil Biology and Biochemistry. 36: 155-164.

Alriksson A., Eriksson, H.M., 1998. Variation in mineral nutrient and C distribution in the soil and vegetation compartments of five temperate tree species in NE Sweden, Forest Ecology and Management. 108: 261-273.

Andersen Ch.P., Nikolov I., Nokolova P., Matyssek R. and Häberle K., 2005. Estimating "autotrophic" belowground respiration in spruce and beech forests: decrease following girdling. European Journal of Forest Research. 124:155-163.

Aubert M. and Burea F. and Vinceslas-Akpa M., 2005. Sources of spatial and temporal variability of inorganic nitrogen in pure and mixed deciduous temperate forests. Soil Biology and Biochemistry. 37 (1): 67 - 79

Augusto L. and Ranger J., 2001. Impact of tree species on soil solutions in acidic conditions. Annal Forest Sciences. 58:47-58.

Augusto L., Ranger J., Binkley D. and Rothe A., 2002, Impact of several common tree species of European temperate forests on soil fertility. Annal Forest Sciences. 59: 233-253.

Bartsch N., 2000. Element release in beech (Fagus sylvatica L.) forest gaps. Water, Air and Soil Pollution.122 (1-2): 3-16.

Beier C., Hansen, K., Gundersen, P., 1993. Spatial variability of throughfall fluxes in a spruce forest. Environmental Pollution. 81: 257-267.

Benecke, P., 1984. Der Wasserumsatz eines Buchen- und eines Fichtenwaldökosystems im Hochsolling. Schriftenreihe aus der Forstl. Fakultät der Universität Göttingen und der Nieders. Versuchsanstalt 77.

Berg B., 1988. Dynamics of nitrogen (N-15) in decomposing Scots pine (Pinus sylvestris) needle litter- long term decomposition in Scots pine forest. Canadian Journal of Botany. 66(8): 1539-1546.

Berg B. and Staaf H., 1980. Decomposition rate and chemical changes of Scots Pine needle litter. II. Influence of chemical composition. Structure and Function of Northern Coniferous Forests - An Ecosystem Study. Ecological Bull.(Stockholm). 
Berg B., 1986. Nutrient release from litter and humus in coniferous forest soils- a mini review. Scandinavian Journal of Forest Research. 1: 359-369.

Berg B. and Taum C.O., 1991. Decomposition and nutrient dynamics of litter in long-term optimum nutrient experiments. I. Organic matter decomposition in Norway spruce (Picea abies) needle litter. Scandinavian Journal of Forest Research. 6:305-321.

Berg B. and Matzner E., 1997. Effect of $\mathrm{N}$ deposition on decomposition of plant litter and soil organic matter in forest ecosystems. Environmental Review. 5: 1 - 25.

Berg B., 2000. Litter decomposition and organic matter turnover in northern forest soils. Forest Ecology and Management, 133: 13-22.

Berg B., Johnsson M.B. and Meetemeyer V., 2000. Litter decomposition in a transect of Norway spruce forest: substrate quality and climate control. Canadian Journal of Forest Research. 30:1136-1147.

Berg B., Gerstberger P. 2004. Element Fluxes with Litterfall in Mature Stands of Norway Spruce and European beech in Bavaria, South Germany. In E.Matzner (Ed.) Biogeochemistry of Forested Catchments in a Changing Environment. Springer-Verlag Berlin Heidelberg. Ecological Studies, Vol. 172: 271-278.

Berger T. W., Neubauer C. and Glatzel G., 2002. Factors controlling soil carbon and nitrogen stores in pure stands of Norway spruce (Picea abies) and mixed species stands in Austia. Forest Ecology and Management. 159: 3-14.

Berger T.W., Swoboda S., Prohaska T., Glatzel G., 2006. The role of calcium uptake from deep soils for spruce (Picea abies) and beech (Fagus sylvatica). Forest Ecology and Management. 229:234-246.

Binkley D. and Giardina C., 1998. Why do tree species affect soils? The warp and worf of tree - soil interaction. Biogeochemistry. 42: 89 - 106.

Binkley D. and Valentine D., 1998, Fifty - years biogeochemistry effects of green ash, white pine, and Norway spruce in a replicated experiment. Forest Ecology and Management, 40: 1325 .

Bjørnlund L. and Christensen S., 2005. How does litter quality and site heterogeneity interact on decomposer food webs of a semi-natural forest? Soil Biology \& Biochemistry. 37:203213.

Bolte A. and Villanueva I. 2006. Interspecific competition impacts on the morphology and distribution of fine roots in European beech ( Fagus sylvaticaL.) and Norway spruce ( Picea abies(L.) Karst.). Eur. J. Forest. Res. 125: 15-26. 
Borken W., Xu Y.J., Davidson E.A. and Beese F., 2002. Site and temporal variation of soil respiration in European beech, Norway spruce, and Scots pine forests. Global Change Biology. 8: 1205-1216.

Borken, W. , 1996. Methan-Aufnahme und Kohlendioxid-Freisetzung von Waldböden. Ber. Forschungszentrum Waldökosysteme. Georg- August Göttingen Univ.

Borken W. and Beese F., 2005. Soil respiration in pure and mixed stands of European beech and Norway spruce following removal of organic horizons. Can. J. For.Res. 35: 2756-2764.

Borken W., Savage K., Davidson E.A. and Trumbore S. Effects of experimental drought on soil respiration and radiocarbon efflux from a temperate forest soil. Global Change Biology. 12:177-193.

Bowden R.D., Nadelhoffer K.J., Boone R.D., Melillo J.M. and Garrison J.B., 1993. Contributions of aboveground litter, belowground litter, and root respiration to total soil respiration in a temperate mixed hardwood forest. Can. J. For. Res. 23:1402-1407.

Braun M., Dieffenbach A. and Matzner E., 2001, Soil solution chemistry in the rhizosphere of beech (Fagus sivatica L.) roots as influenced by ammonium supply. Journal of plant nutrient and soil science- Zeitschrift für Pflanzenernährung und Bodenkunde 164 (3): 271-277.

Bredemeier M., 1988, Forest canopy transformation of atmospheric deposition. Water, Air and Soil Pollution.40: 121- 138.

Brumme R. and Beese F., 1992. Effects of liming and nitrogen fertilization on emission of $\mathrm{CO}_{2}$ and $\mathrm{N}_{2} \mathrm{O}$ from a temperate Forest. Journal of Geophysical Research. 97: 12851-12858.

Brumme R., 1995. Mechanisms of carbon and nutrient release and retention in beech forest gaps. Plant and Soil. 168-169:593-600.

Burke M. K. and Raynal D. J., 1994. Fine root growth phonology, production and turnover in a northern hardwood forest ecosystem. Plant and Soil. 162:135-146.

Buchmann N., 2000. Biotic and abiotic factors controlling soil respiration rates in Picea abies stands. Soil Biology and Biochemistry. 32:1625-1635.

Chang, S.-C., Matzner, E., 2000. The effect of beech stemflow on spatial patterns of soil solution chemistry and seepage fluxes in a mixed beech/oak stand. Hydrological Processes 14: 135-144.

Chapmann K., Wittaker J.B. and Heal O.W., 1988. Metabolic and faunal activity in litters of tree mixtures compared with pure stands. Agric.- Ecosys. Environ. 24: 33-40. 
Cheussom L. 2004. Hydrological Pattern in a Mixed Forest of Northern Germany. Desseretation-Georg-August Göttingen University.

Christiansen J.R., Elberling B. and Jansson P.-E., 2006. Modelloing water balance and nitrate leaching in temperate Norway spruce and beech forest located on the same soil type with the CoupModel. Forest Ecology and Manegement. 237: 545 - 556.

Codack M., Ludwig B. and Beese F., 2002. An equation to describe vertical gradients of element concentrations in soils under beech and spruce stands. Journal of Plant Nutrition and Soil Science. 165: $602-608$.

Couteaux M.M., Bottner P. and Berg B., 1995. Litter decomposition, climate and litter quality. Trends Ecological Evolution. 10:63-66.

Dawson T. and Brooks P., 2001. Fundamental of stable Isotope chemistry and measurements. Chapter 1 of Stable Isotope Techniques in the study of Biological Processes and Functioning of Ecosystems, 1-18. Kluwer Academic publishers. Printed in the Neterlanads.

Devlaeminck R., de Schrijver A., and Hermy M., 2005, Variation in throughfall deposition across a deciduous beech (Fagus sylvatica L.) forest edge in Flanders. Sci. Total Environ. 337: $241-525$.

Didham R.K., 1998. Altered leaf litter decomposition rates in tropical forest fragments. Oecologia. 116(3): 397-406.

Dignac M., Kögel- Knabner I., Michel K., Matzner E. and Knicker H., 2002. Chemistry of soil organic matter as related to $\mathrm{C}$ : $\mathrm{N}$ in Norway spruce forest (Picea abies (L.) Karst) floors and mineral soils. Journal of Plant Nutrition and Soil Sciences. 165: 281-289.

Dijkstra F. A., Hobbie S. E., Knops J. M. H. and Reich P. B., 2004. Nitrogen deposition and plant species interact to influence soil carbon stabilisation. Ecology Letters. 7: 1192-1198.

Duchesne L., Ouimet R., Camire C. and Houle D., 2001. Seasonal nutrient transfers by foliar resorption, leaching, and litterfall in a northern hardwood forest at lake Clair Watershed, Quebec, Canada. Canadian Journal of Forest Research. 33(2): 333-344.

Elberling B. and Ladegaard-Pedersen P., 2005. Subsurface CO2 dynamics in temperate beech and spruce forest stands. Biogeochemistry. 75:479-506.

Ellenberg H., Mayer R. and Schauermann J., 1986. Ökosystemforschung - Ergebnisse der Sollingprojektes. Eugen Ulmer Verlag, Stuttgart, Germany.

Epron D., Ngao J. and Granier A., 2004. Interannual variation of soil respiration in a beech forest ecosystem over a six- year study. Annal Forest Sciences. 61: 499-505. 
Fang C., Moncrieff J.B., Gholz H.L. and Kenneth L.C., 1998. Soil CO2 efflux and ist spatial variation in Florida slash pine plantation. Plant and Soil. 205:135-146.

Feng Z., Brumme R., Xu Y.-J. and N. Lamersdorf, 2007. Tracing the fate of mineral N compounds under high ambient $\mathrm{N}$ deposition in a Norway spruce forest at Solling / Germany. Forest Ecology and Mangement. In press.

Ferrari, J. B. 1999. Fine-scale patterns of leaf litterfall and nitrogen cycling in an old-growth forest. Canadian Journal of Forest Research. 29, 291 - 302.

Finiz A. C. and Canham C. D., 1998. Non additive effects of litter mixtures on net N mineralisation in a southern New England forest. - Forest Ecology and Management. 105: $129-136$.

Fisher R.F. and Binkley D., 2000. Ecology and management of forest soils. Wiley, New York.

Fogg K., 1988. The effect of added nitrogen on the rate of decomposition of organic matter. Biological Review. 63:433-462.

Friedrich J., 1992. Räumliche Variation bodenchemischer und physikalischer Merkmalsgrößen sowie der Wurzelverteilung in Buchen- und Fichtenwaldökosystemen. Bereichte des Forschungszentrums Waldökosysteme d. Univ. Göttingen.

Gartner T. and Cardon Z., 2004. Decomposition dynamics in mixed-species leaf litter. Oikos. 104:230-246.

Gashe R., Papen H., 1999. A 3-yera continuous record of nitrogen trace gas fluxes from untreated and limed soil of a $\mathrm{N}$ saturated spruce and beech forest ecosystem in Germany. 2. NO and NO2 fluxes. J. Geoüphysical Research. 104: 18505-18520.

Gebauer G., Zeller B., Schmidt G., May C., Buchmann N., Colin-Belgrand M., Dambrine E., Martin F., Schulze E.-D. and Bottner P., 2000. The fate of 15N-Labelled nitrogen inputs to coniferous and broadleaf forests. Ecological Studies 142, Springer -Verlag Berline Heidelberg.

Gessler A., Schneider S., Vonsengbusch D., Weber P., U. Hanemann, Huber Ch., Rothe A., Krutzer K. and Rennenberg H., 1998. Field and laboratory experiments on net uptake of nitrate and ammonium by the roots of spruce (Picea abies) and beech (Fagus sylvatica) trees. New Phytol. 138: 275-285.

Gill R. A. and Jackson R., 2000. Global patterns of root turnover for terrestrial ecosystems. New Phytol. 147:13-31. 
Göransson H., Wallaner H., Ingerslev M. and Rosengren U., 2006. Estimating the relative nutrient uptake from different soil depths in Quercus robur, Fagus sylvatica and Picea abies. Plant and Soil. 286:87-97.

Gower S.T. and Son Y., 1992. Differences in soil and leaf litterfall nitrogen dynamics for 5 forest plantations. Soil Science Society of American Journal. 56(6): 1959-1966.

Hagen-Thorn A., Callesen I., Armolaitis K. and Nihlgard B., 2004. The impact of six European tree species on the chemistry of mineral topsoil in forest plantations on former agricultural land. For. Ecol. Manage. 195: 373-384.

Hagen-Thorn, A., Varnagiryte, B., Nihlgard, B., and Armolaitis, K., 2006, Autumn nutrient resorption and losses in four deciduous forest tree species. Forest Ecology and Management. 228 (1-3): 33-39.

Hansen, K., 1995, In-Canopy throughfall measurements in Norway spruce: Water flow and consequences for ion fluxes. Water, Air, and Soil Pollution. 85: 2259-2264.

Haim A. and Frey B., 2004. Early stage litter decomposition rates for Swiss forests. Biogeochemistry. 70: $299-313$.

Heinrichs,H. (1989): Aufschlussverfahren in der analytischen. Geochemie (Teil 1). Labor Praxis 12/89: 1140-1146.

Hanson P. J., O’Neill E.G. and Chambers M.L.S., 2003. Soil respiration and litter decomposition. In : North American Temperate Deciduous Forest Responses to Changing Precipitation Regimes (eds hanson P.J., Wullschleger SD), pp. 163-189. Springer, New York.

Hooper, D.U., Chapin, F.S. Ewel, J.J., Hector, A., Inchausti, P., Lavorel, S., Lawton, J.H.

Lodge, D.M., Loreau, M., Naeem, S., Schmid, B., Setälä, H., Symstad, A.J., Vandermeer,J., Wardle,D.A., 2005. Effects of biodiversity on ecosystem functioning: a consensus of current knowledge. Ecol. Monogr. 75, 3-35.

Jönsson U., Rosengren U., Thelin G. and Nihlgård B., 2003. Acidification- induced chemical changes in coniferous forest soils in southern Sweden 1988-1999. Environmental Pollution 123: $75-83$.

Joergensen R.G. and Meyer B., 1989. Nutrient changes in decomposing beech leaf litter assessed usinmg a solution flux approach. Journal of Soil Sciences. 41:279-293.

Johnson D.W. and Curtis P.S., 2001. Effects of forest management on soil C and N storage: meta analysis. Forest Ecology and Management. 140:227-238.

Kindlmann, P., Stadler, B., 2004, Temporal fluctuations in throughfall Carbon concentrations in a spruce forest. Ecological Modlleing. 176 (3-4): 381-388. 
Khanna, P. K. und Ulrich, B., 1991, Ecochemistry of temperate deciduous forests. In Röhrig, E. und Ulrich, B., editors, Ecosystems of the World, chapter 7. Elsevier. [ibwg0789]

Koch A.S. and E. Matzner, 1993, Heterogeneity of soil and soil solution chemistry under Norway spruce (Picea abies Karst.) and European beech (Fagus silvatica L.) as influenced by distance from the stem basis. Plant and Soil 151: 227-237

Köstler, J.N., Brückner, E. and Biebelriether, H., 1968. Die Wurzeln der WaldbäumeUntersuchungen zur Morphologie der Waldbäume in Mitteleuropa., Paul Parey, Hamburg pp. 284 .

Knorr M., frey S. D. and Curtis P. S., 2005. Nitrogen additions and litter decomposition: A meta- analysis. Ecology. 86(21): 3252-3257.

Langusch, J., Borken, W., Armbruster, M., Diese, N., and Matzner, E., 2003, Canopy leaching of cations in central European forest ecosystems - a regional assessment. Journal of Plant Nutrition and Soil Science. 166:168-174.

Larsen, B. 1995. Ecological stability of forests and sustainable silviculture. Forest Ecology and Management. 73:85-96.

Lebret M., Nys C., and Forgeard F., 2001, Litter production in an Atlantic beech (Fagus sylvatica L.) time sequence. Annal Forest Science. 58: 755-768

Levia Jr., D.F., Frost, E.E., 2003. A review and evaluation of stemflow literature in the hydrologic and biogeochemical cycles of forested and agricultural ecosystems. Journal of Hydrology. 274: 1-29.

Lovett G.M. 1994, Atmospheric deposition of nutrients and pollutants in North America: an ecological perspective. Ecological Application. 4: 629-650.

Lovett, G.M., Nolan, S.S., Driscoll, C.T., Fahey, T.J., 1996. Factors regulating throughfall flux in a New Hampshire forested landscape. Canadian Journal of Forest Research. 26: 21342144.

Lytle D.E. and Cronan Ch.S., 1998. Comparative soil CO2 evolution, litter decay, and root dynamics in clearcut and uncut spruce-fir forest. Forest Ecology and Management. 103:121128.

Majdi H. and Persson H., 1993. Spatial distribution of fine roots, rhizosphere and bulk- soil chemistry in an acidified Picea abies stand. Scandinavian Journal of Forest Research. 8: 147155 . 
Majdi H., 2004. Root and needle litter decomposition responses to enhanced supplies of $\mathrm{N}$ and $\mathrm{S}$ in a Norway spruce forest in southwest Sweden. Plant Biosystems. 138:225-230.

Mandersheid, B. and Matzner, E., 1995. Spatial heterogeneity of soil solution chemistry in a mature Norway spruce (Picea abies (L.) Karst.) stand. Water, Air and Soil Pollution. 85: 1185-1190.

Matschonat G. and Falkengren-Grerup U., 2000. Recovery of soil pH, Cation-exchange Capacity and the Sturation of Exchange Sites from Stemflow-induced Soil Acidification in Three Swedish Beech (Fagus sylvatica L.) Forests. Scandinavian Journal of Forest Research.15 :39-48

Matzner, E., 1988. Der Stoffumsatz zweier Waldökosysteme im Solling. Berichte des Forschungszentrums Waldökosysteme/Waldsterben. A40:1-217.

McClaugherty C.A., Pastor J., Aber J.D. and Melillo J.M., 1985. Forest litter decomposition in relation to soil nitrogen dynamics and litter quality. Ecology. 66:266-275.

McCormik L.H. and Steiner K. C., 1978, Variation in Aluminium tolerance among six genera of trees. Forest Sciences. 24: 565-568

Meesenburg H, Meiwes KJ, Rademacher $\mathrm{P}$ et al. 1995. Long term trends in atmospheric deposition and seepage aoutput in northwest German forest ecosystems. Water, Air and Soil Pollution. 85: 611-616.

Mulder J. and Cresser M.S., 1994. Soil and Soil Solution Chemistry. Chapter 5, Biogeochemistry of small catchments: A tool for Environmental Research. Edited by: B. Moldan and J. Cerny. Published by John Wiley \& Sons Ltd.

Muys B., Lust N. and Granval P., 1992. Effect of grassland affoerestation with different tree species on earthworm communities, litter decomposition and nutrient status. Soil Biology \& Biocghemistry. 24(12): 1459-1466.

Nihlgård, B.,1970, Precipitation, its chemical composition and effect on soil water in a beech and a spruce forest in south Sweden. Oikos. 21: 208-217.

Nihlgård, B.,1970, Plant biomass, primary production and distribution of chemical elements in a beech and a planted spruce forest in South Sweden. Oikos. 23: 69-81.

Norden U., 1994. Influence of tree species on acidification and mineral pools in deciduous forest soils of south Sweden. Water, Air and Soil Pollution 76: 363-381.

Nordén U. 1991, Acid deposition and throughfall fluxes of elements as related to tree species in deciduous forests of South Sweden. Water, Air and Soil Pollution.60: 209 - 230. 
Nordén U. 1994, Leaf litterfall concentrations and fluxes of elements by deciduous tree species. Scandinavian Journal of Forest Research. 9(1): 9-16.

Olsen J. S., 1963. Energy storage and the balance of producers and consumers in ecological systems. Ecology. 44: 322-331.

Olsthoorn, AFM, Bartelink HH, Gardiner JJ, Pretzsch H, Hekhuis HJ, Franc A [eds.], 1999. Management of mixed-species forest: silviculture and economics. IBN Scient. Contrib. 15: $1-389$

Oulehle, F., Hruška, J., 2005, Tree species (Picea abies and Fagus sylvatica) effects on soil water acidification and aluminium chemistry at sites subjected to long-term acidification in the Ore Mts., Czech Republic. Journal of Inorganice Biochemistry. 99:1822-1829.

Parker G.G., 1983, Throughfall and stemflow in the forest nutrient cycle. Advance Ecological Research. 13: 57-133.

Pederson L.B., and Bille-Hansen J., 1999, A comparison of litterfall and element fluxes in even aged Norway spruce, sitka spruce and beech stands in Denmark. Forest Ecology and Management. 114: 55-70.

Persson H., 1979. Fine-root production, mortality and decomposition in forest ecosystems. Vegetation American Journal of Botany. 89:812-819.

Perry D. A., Choquette C. and Schroeder P.,1987. Nitrogen dynamics in coniferousdominated forests with and without hardwoods. Canadian Journal of Forest Research. 17(11): 1434-1441.

Persson H, Ahlstöm K, and Clemensson-Lindle A.1998. Nitrogen addition and removal at Gadjön- effect on fine root growth and fine root chemistry. Forest Ecology and Management. 101: 204-208

Prescott C.E., 1995. Does nitrogen availability control rates of litter decomposition in forests? Plant and Soil. 168-169: 83-88.

Prescott C. E., 2002. The influence of forest canopy on nutrient cycling. Tree Physiology. 22: 1193-1200.

Puhe J., 2003. Growth and development of the root system of Norway spruce (Picea abies) in forest stands-a review. Forest Ecology and Management.175: 253-273.

Raich J.W. and Nadelhoffer K.J., 1989. Belowground carbon allocation in forest ecosystems: Global trends of Ecology. 70:1345-1354. 
Raich J. W. and Tufekcioglu A., 2000. Vegetation and soil respiration: Correlations and controls. Biogeochemistry. 48:71-90.

Ranger J. and Nys C., 1994. The effect of spruce (Picea abies Karst.) on soil development: an analytical and experimental approach. European Journal of Soil Science. 45(2): 193-204.

Raat K. J., Draaijers G.P.J., Scaap M.G., Tietema A. and Verstraten J. M., 2002. Spatial variability of throughfall water and chemistry and forest floore water content in a Douglas fir forest stand. Hydrology and Earth system Sciences. 6(3): 363-374.

Raulund-Rasmussen K. and Vejre H., 1995. Effect of tree species and soil properties on nutrient immobilization in the forest floor. Plant and soil. 167-169: 345-352.

Rennenberg H., Kreuzer K., Papen H. and Weber P., 1998. Consequences of high loads of nitrogen for spruce (Picea abies L.) and beech (Fagus sylvatica L.) forestes. New Phytology. 139: 71-86.

Reuss J. O. and Johnson D. W., 1986. Acid deposition and the acidification of soils and waters. Ecological Studies 59, Springer Verlag, New York.

Riha S., Senesac G. and Pallant E., 1986. Effects of forest vegetation on spatial variability of surface mineral soil pH, soluble aluminium and carbon. Water, Air and Soil Pollution. 31: 929-940.

Ritter E., Dalsgaard L. and Eirthorn K.S., 2005. Light, temperature and soil moisture regimes following gap formation in a semi-natural beech-dominated forest in Denmark. Forest Ecology and Management. 206 (1-3): 15-33.

Ritter E. and Vesterdal L., 2006. Gap formation in Danish beech (Fagus sylvatica) forests of low management intensity: soil moisture and nitrate in soil solution. European Journal of Forest Research. 125:139-150.

Rothe A. 1997, Einfluß des Baumarten-anteils auf Durchwurzelung, Wasserhaushalt, Stoffhaushalt und Zuwachsleistung eines Fichten-Buchen-Misch-bestandes am Standort Höglwald.Schriftenreihe der Forstwissenshaftlichen Fakultät der Universität München und der Bayerischen Landesanstalt für Wald und Forstwirtschaft. Dissertation.

Rothe, A., Binkley, D., 2001, Nutitional interactions in mixed species forests: a synthesis. Candian Journal of Forest Research. 31: 1855-1870.

Rothe, A., Huber, Ch., Kreutzer, K., and Weis, W., 2002 (a), Deposition and soil leaching in stands of Norway spruce and European Beech: Results from the Höglwald research in comparison with other European case studies. Plant and Soil. 240: 33-45. 
Rothe A., Kreutzer K. \& Küchenhoff H. 2002 (b), influence of tree species composition on soil and soil solution properties in two mixed spruce-beech stands with contrasting history in Southern Germany. Plant and Soil. 240: 47-56.

Rothe A., Ewald J. and Hibbs D. E., 2003, Do admixed broadleaves improve foliar nutrient status of conifer tree crops? Forest Ecology and Management.172: 327-338.

Růžička, Š.,1994, Throughfall quality and quantity in polluted and damaged ecosystems in Northern Bohemia. Water, Air, and Soil Pollution. 83: 205-218.

Sarilyildiz T., Tüfekçioğlu A. and Küçük M., 2005. Comaprison of decomposition rates of beech (Fagus orientalis Lipsky) and spruce ( Picea abies (L.) Link) litter in pure and mixed stands of both species in Artvin, Turkey. Turkish Journal of Agricalture and Forestry. 29: 429-438.

Schmid, I., 2002, The influence of soil type and interspecific competition on the fine root system of Norway spruce and European beech. Basic and Applied Ecology. 3: 339-346(8)

Schmid I.; Kazda M., 2002, Root distribution of Norway spruce in monospecific and mixed stands on different soils. Forest Ecology and Management. 159(1): 37-47.

Scott N. A. and Binkley D., 1997. Foliage litter quality and annual net mineralisation: comparison across North American Forest sites. Oecologia. 111: 151 - 159.

Seiler, J., Matzner, E., 1995. Spatial variability of throughfall chemistry and selected soil properties as influenced by stem distance in a mature Norway spruce (Picea abies, Karst.) stand. Plant and Soil. 176: 139-147.

Søe A.R.B. and Buchmann N., 2005. Spatial and temporal variations in soil respiration in relation to stand structure and soil parameters in an unmanaged beech forest. Tree Physiology. 25:1427-1436.

Stachurski, A., Zimka, J.R., 2002. Atmospheric deposition and ionic interactions within a beech canopy in the Karkonosze Mountains. Environmental Pollution. 118: 75-87.

Stadler, B., Sollinger, S., Michalzik, B., 2001. Insect herbivores and the nutrient flow from the canopy to the soil in coniferous and deciduous forests. Oecologia. 126: 104-113.

Staelens, J., De Schrijver, A., Verheyen, K., Verhoest, N.E.C., 2006, Spatial variability and temporal stability of throughfall water under a dominant beech (Fagus sylvatica L.) tree in relationship to canopy structure. Environmental Pollution. $142: 254-263$.

Staaf H., 1988. Litter decomposition in beech forests- effects of excluding tree roots. Biology and Fertility of Soils. 6: 302-305. 
Subke J. A., Reichstein M. and Tenhunen J.D., 2003. Explaining temporal variation in soil $\mathrm{CO} 2$ efflux in amature spruce forest in southern Germany. Soil Biology \& Biochemisty. 35 : 1467-1483.

Sverdrup H and Stjernquist I. 2002. Developing Principles and Models for Sustainable Forestry in Sweden. Kluwer Academic Publishers Dordrecht Holland.

Tewary C.K., Pandy U. and Singh J.S., 1982. Soil and litter respiration rates in different microhabitats of a mixed oak-conifer forest and their control by edaphic conditions and subtrate quality. Plant and Soil. 65:233-238.

Thelin G., Rosengren U., Callesen I. and Ingerslev M., 2002, The nutrient status of Norway spruce in pure and in mixed-species stands. Forest Ecology and Management. 160: 115-125

Toba T. and Ohta T., 2005. An observational study of the factors that influence interception loss in boreal and temporate forests. Journal of Hydrology. 313: $208-220$.

Ulrich B., Ahren E. and Ulrich M., 1971, Soil chemical differences between beech and spruce sites- an example of the metods used. Ecological Studies. Springer Verlag, New York.

Ulrich B., 1989. Effects of acidic precipitation on forest ecosystems in Europe. In: D.C. Adriano and A.H. Johnson (Editors), Acidic precipitation: Biological and Ecological effects. Springer-Verlag, Heidelberg.

Ulrich B., 1994, Nutrient and acid - base budget of central European forest ecosystem. Chapter 1, Effects of acid rain on forest processes. Edited by: Godbold D., and Hüttermann A.,Wiley-Liss publication.

Versterdal L. and Raulund-Rasmussen k., 1998. Forest floor chemistry under seven tree species along a soil fertility gradient. Canadian Journal of Forest Research. 28: 1636 - 1647.

Versterdal L., 1999. Influence of soil type on mass loss and nutrient release from decomposing foliage litter of beech and Norway spruce. Canadian Journal of Forest Research. 29: $95-105$.

Viville, D., Biron, P., Granier, A., Dambrine, E. and Probst, A. (1993) Interception in a mountainous declining spruce stand in the strengbach catchment (Vosges, France). Journal of hydrology. 144, 273-282.

Vogt K. A., Grier C. C., Meier C. E. and Keyes M. R., 1983. Organic- matter and nutrient dynamics in forest floors of young and mature Abies- amabilis stands in western Washington, as affected by fine-roots input. Ecological Monography. 53(3): 139-157. 
Vogt K. A., Vogt D. J., Palmiotto P.A., Boom P., O’Hara J. and Asbjornsen H., 1996. Review of root dynamics in forest ecosystems grouped by climate, climatic forest type and species. Plant and Soil. 187:159-219.

Weber M. G., 1990. Forest soil respiration after cutting and burning in immature aspen ecosystems. Forest Ecology and Management. 31:1-14.

Whelan, M.J., Anderson, J.M., 1996. Modelling spatial patterns of throughfall and interception loss in a Norway spruce (Picea abies) plantation at the plot scale. Journal of hydrology. 186: 335-354.

Whelan, M.J., Sanger, L.J., Baker, M., Anderson, J.M., 1998. Spatial patterns of throughfall and mineral ion deposition in a lowland Norway spruce (Picea abies) plantation at the plot scale. Atmospheric Environment. 32: 3493-3501.

Wilpert K.V., and Mies E., 1995, The influence of stand structure and tree species on mineral cycling. In Nutrient uptake and cycling in forest ecosystems. European Commission, Brussels. Off. Publ. 8.

Wilpert K.V., Zirlewagen D. and Kohler M., 2000, To what extent can silviculture enhance sustainability of forest sites under the immission regime in central Europe? Water, Air, and Soil Pullution.122: 105-120.

Xu Y.-J., Blanck K., Bredemeier M. and Lamersdorf N.P., 1998. Hydrochemical input-output budgets for a clean rain and drought experiment at Solling. Forest Ecology and Management. 101: $295-306$.

Xu M. and Qi Y., 2001. Soil-surface CO2 efflux and its spatial and temporal variations in a young ponderosa pine plantation in northern California. Global Change Biology. 7:667-677.

Yang Y. S., Guo J.F., Chen G.S., Xie J.S., Cai L. P., and Lin P., 2004, Litterfall, nutrient return, and leaf-litter decomposition in four plantations compared with a natural forest in subtropical China. Annal Forest Sciences. 61: 465-476

Yang WQ, Wang KY, Kellomaski S, Gong HD, 2005, Litter dynamics of three subalpine $\begin{array}{llllll}\text { forests in Western } & \text { Sichuan. Pedosphere. } & \text { 653-659 }\end{array}$

Zinke P.J., 1962, The pattern of individual forest trees on soil properties. Ecology. 43: 130133.

Zirlewagen, D., von Wilpert, K., 2001. Modelling water and ion fluxes in a highly structured, mixed-species stand. Forest Ecology and Management. 143:27-37. 


\section{Curriculum vita}

Name, first name:

Date of birth:

Place of birth:

Family status:

Nationality:

\section{Education:}

$1988-1991$

$1992-1997$

$1997-1999$

Nov. 2003 - Oct. 2007
Hojjati, Seyed Mohammad

3 Nov. 1974

Babol- Iran

Married since Sep. 2000 and has a son.

Iranian

High school diploma in Natural Sciences, Babol - Iran

Bachelor of Science (B.Sc degree), Forestry, Faculty of Forestry, Natural Resources and Agricultural University of Gorgan - Iran.

Master of Science (M.Sc degree), Forestry, Department of Forestry, Natural Resources Faculty, Tehran University, Tehran - Iran

Awarded a scholarship for Ph.D program from Iranian Ministry of Sciences, Research and Technology (MSRT). Research associate at the Georg-August - Göttingen University, Buesgen Institute, Soil Sciences in Temprate and Boreal Ecosytems.

\section{Work experience:}

June 1997 - Oct. 1997

Oct.1997 - May 1999

Apr.1999 - Aug.1999

June 1999 - July 2001

Feb. 1999 - Oct. 2003

\section{Military Service}

Research associate in the project "Distribution and age structure of natural regeneration in beech (Fagus orientalis) stands- North of Iran" at the department of Forestry- Tehran University.

Research associate in the project "Natural structure of beech stand (Fagus orientalis) in North of Iran" at the Iranian Research Institute of Forests and Rangelands.

Lecture in "Natural Resources" in the educational centre of Jahad-e- Keshavarzi, Mazandaran - Iran

Expert of Forestry in the Ministry of Natural Resources of Mazandaran, Sari - Iran. 


\section{Publications:}

Mattaji A. S., Hojjati M. S., and Namiranian M., 2002. A study of tree distribution diameter classes in natural beech (Fagus orientalis L.) stand with using probability distribution. Iranian Journal of Natural resources. 53(2): 51-60.

Hojjati S. M., Hagen-Thorn A., and Lamersdorf N. P., 2007. Canopy composition as a measure to identify patterns of nutrient input in a mixed European beech and Norway spruce forest in central Europe. European Journal of Forest Research. Accepted. 